\title{
The UK Tax System and the Environment
}

\author{
Andrew Leicester
}

Copy-edited by Judith Payne

The Institute for Fiscal Studies

7 Ridgmount Street

London WC1E 7AE 


\author{
Published by \\ The Institute for Fiscal Studies \\ 7 Ridgmount Street \\ London WC1E 7AE \\ tel. +44 (0) 2072914800 \\ fax +44 (0) 2073234780 \\ email: mailbox@ifs.org.uk \\ http://www.ifs.org.uk
}

(C) The Institute for Fiscal Studies, October 2006

ISBN-10: 1-903274-47-8

ISBN-13: 978-1-903274-47-7

Printed by

Patersons, Tunbridge Wells 


\section{Preface}

The research in this report was produced with generous funding and support from the Esmée Fairbairn Foundation. The author is extremely grateful to Mike Brewer of IFS, Darren Greedy at HM Treasury, Ronan Palmer at the Environment Agency, Danyal Sattar of the Esmée Fairbairn Foundation and Stephen Smith of University College London for invaluable comments, advice and discussion. Any errors remain his own. 



\section{Contents}

Executive summary

$\begin{array}{ll}\text { 1. Introduction } & 1\end{array}$

2. The rationale for environmental taxation 3

2.1 Pros and cons of using environmental taxes 4

2.2 What should be taxed? 6

3. Environmental tax revenues 9

3.1 Trends in total revenues 9

3.2 Who pays environmental taxes in the UK? 12

3.3 How does the UK compare internationally? 13

4. A history of emissions and emissions targeting in the UK 15

$\begin{array}{ll}\text { 4.1 Trends in UK emissions } & 15\end{array}$

$\begin{array}{ll}\text { 4.2 The UK in international perspective } & 19\end{array}$

5. Green taxes and other instruments currently in use in the UK 21

$\begin{array}{ll}5.1 \text { Taxes on transport } & 23\end{array}$

$\begin{array}{ll}5.2 \text { Taxes on waste and natural resources } & 47\end{array}$

$\begin{array}{ll}5.3 \text { Taxes on energy } & 58\end{array}$

6. The future of environmental taxation? $\quad 70$

$\begin{array}{ll}6.1 \text { Road user charging } & 70\end{array}$

$\begin{array}{ll}\text { 6.2 Carbon tax } & 72\end{array}$

$\begin{array}{ll}\text { 6.3 Taxes on plastic bags } & 74\end{array}$

$\begin{array}{ll}\text { 7. Conclusion } & 76\end{array}$

$\begin{array}{ll}\text { References } & 77\end{array}$ 



\section{Executive Summary}

This report takes a broad overview of the UK environmental tax system as it exists in 2006. It aims to bring together evidence and data from a range of sources to provide a central source of information about the existing environmental tax system, alongside discussion of the key principles of the debate around using taxes and other economic instruments for environmental goals. The report assesses broad trends over time - both in environmental tax revenues and in greenhouse gas emissions, the latter with respect to the government's own emissions-reduction targets and the Kyoto Protocol. It also examines current measures case by case, considering and commenting on the history, motivation, design and implementation of each tax, evidence on the effects (both intentional and perhaps unintentional), trends in revenue and, where important, any distributional implications. Taxes are considered under three broad headings: transport, natural resources and energy. The report looks at new taxes designed explicitly for environmental ends (such as the climate change levy), taxes that were not environmental in intention but have environmental consequences (such as fuel duty), taxes that were altered to incorporate a more obvious environmental objective (such as changes to VAT) and non-tax measures that nevertheless provide economic incentives for pollution reduction (such as the UK and EU Emissions Trading Schemes).

The report is not designed to be prescriptive - it does not suggest or encourage that particular policies be changed or introduced, nor does it try to estimate how far current policy will go in the future to meet environmental objectives. Rather, it is designed as a factual overview of where current policy has taken us. However, it does consider some possible future reforms to the environmental tax system - road user charging, carbon taxes and taxes on packaging waste (plastic carrier bags) that have been suggested.

In a report of this nature, it is, of course, extremely difficult to summarise the findings as a whole for each part of the environmental tax system. Some of the key results, both general and for particular tax measures, are, however, presented here.

\section{The rationale for environmental taxation}

- Environmental taxes are usually justified by the externalities argument: from society's perspective, too much pollution is generated by polluters who do not take into account the effects of their actions on others.

- This does not mean that an optimal level of pollution is (in general) zero reducing emissions has a cost, and emissions should be reduced to the point where the cost of reducing emissions a little bit more is the same as the benefit to society of that extra abatement.

- Taxes and economic instruments may have particular benefits over using regulatory approaches to environmental problems, in particular to do with static efficiency (minimising the costs of achieving a particular level of pollution reduction), dynamic efficiency (providing incentives for ongoing abatement) and revenue-raising. 
- However, there are also possible drawbacks to environmental taxes - in particular, the uncertainty they can create in terms of the final level of emissions. There is a trade-off between meeting a guaranteed target at uncertain total cost using a regulatory approach and meeting an uncertain target at least cost using environmental taxation.

- Emissions trading schemes may provide the benefits of both approaches since the total level of emissions is fixed by the initial amount of permits to pollute that are provided, and trading should ensure that the cost of abatement to that level is minimised. However, if there are imperfections in the market created for the permits, this may not hold.

- There may also be distributional implications of using environmental taxes or trading schemes, which typically are thought to impact most on the poorest households.

\section{Tax revenues}

- $\quad$ Environmental taxes provided around £35 billion to the government in 2004.

- Around 90 per cent of this revenue was accounted for by fuel duties (and associated VAT) and vehicle excise duty.

- In real terms, however, total revenues peaked in 2000 at almost $£ 37$ billion.

- As a share of national income, environmental tax revenues peaked in 1999 at 3.6 per cent. By 2004, this had fallen to 3.0 per cent.

- As a share of total tax revenue, environmental tax revenues peaked in 1999 at 9.8 per cent. By 2004, this had fallen to 8.3 per cent.

- The major reason for this decline has been the abandonment of the 'fuel duty escalator' in 1999. In real terms, fuel duty (and associated VAT) rose from $£ 19.2$ billion in 1993 to $£ 30.0$ billion in 1999, but by 2004 real revenue had declined to $£ 27.5$ billion.

- Declining revenues from environmental taxes need not imply that a less activist approach is being taken to environmental policy - measures such as emissions trading and reforms to VAT do not show up in revenue figures, and reforms to existing measures to give them a greener hue (such as vehicle excise duty) have also been carried out.

- Amongst OECD economies, Turkey and the Scandinavian nations take the largest shares of GDP in environmental taxes. The UK obtains a greater share of tax revenue and a greater share of GDP in environmental measures than the OECD averages. The US takes the smallest share of both total revenues and GDP in environmental taxes.

\section{Emissions and emissions targeting in the UK}

- Under the Kyoto Protocol, the UK has a target to reduce emissions of greenhouse gases by 12.5 per cent by 2008-12 relative to their 1990 levels. This implies a cut from around 210 million tonnes of carbon equivalent (MtCe) to $186 \mathrm{MtCe}$.

- This target was hit as early as 1999; since then, emissions have stabilised just below the target level. A large amount of the reduction can be attributed to the 'dash for gas' in electricity generation in the 1990s. 
- The UK government has a domestic target to reduce emissions of $\mathrm{CO}_{2}$ by 20 per cent by 2010 compared with the 1990 level. This implies a cut from 161 MtCe to 129 MtCe.

- Up to 1999, the government was broadly on track to hit this target. Since then, $\mathrm{CO}_{2}$ emissions have risen. To hit the target would require an annual reduction in emissions of 3.3 per cent up to 2010.

- Between 1990 and 2003, $\mathrm{CO}_{2}$ emissions from industry and commerce fell substantially, by 17 per cent and 12 per cent respectively. Emissions from households and other sources barely changed, whilst emissions from transport rose by 8 per cent.

- By 2003, transport accounted for 27.3 per cent of total $\mathrm{UK} \mathrm{CO}_{2}$ emissions and industry 28.1 per cent. It is likely that transport will become the largest source of emissions - if not already, then in the very near future.

\section{Taxes on transport}

- Over the last 15 years or so, the price of private transport has fallen relative to earnings whilst public transport costs have risen. This helped contribute to an increase in road traffic volume of 22 per cent between 1990 and 2004.

- External costs from motoring are varied and a single tax may not deal well with them all. Fuel taxes are good at capturing the external costs of $\mathrm{CO}_{2}$ emissions but not the costs of congestion or accidents.

- Vehicle excise duty (VED) was reformed in 2001 such that the amount paid depends on the type of fuel and the emissions rating of the vehicle. The gap between annual VED rates for the lowest- and highest-emissions vehicles rose from $£ 55$ in 2001-02 to £210 in 2006-07.

- VED does not provide incentives to drive less, but it does incentivise motorists to choose more fuel-efficient vehicles. Average new car emissions fell from $190 \mathrm{~g}$ of $\mathrm{CO}_{2}$ per $\mathrm{km}$ in 1997 to $169 \mathrm{~g}$ in 2005, though the downward trend began before the reforms to VED.

- $\quad$ The fuel duty escalator ensured that real duties rose each year between 1993 and 1999, but it was abandoned in November 1999 (before the fuel price protests of 2000). By February 2006, real fuel duty was at its lowest since June 1997, declining by almost 21 per cent for diesel compared with March 1999 peaks. Had real duty levels been maintained at their March 1999 levels, revenue may now be around $£ 4.2$ billion per year higher.

- Fuel duty is regressive amongst car-owning households but not across the whole population, since rates of car ownership are much lower for poorer households.

- Fuel duty provides incentives to reduce the distance driven and to choose more fuel-efficient vehicles. A recent survey estimates that a 10 per cent increase in fuel prices reduces traffic volume by 3 per cent in the long run.

- Between 1990 and 2004, emissions from aviation more than doubled. Reforms to air passenger duty (APD) in 2001, however, halved its rate for most people flying within the EU. 
- APD can provide incentives at the margin to reduce flight volumes. A recent review suggests that a 10 per cent increase in the price of flights reduces demand for long-haul leisure flights by 10 per cent and short-haul by 15 per cent. The effect on business flights is typically very small.

- Since emissions from flights are roughly the same whether the plane is full or empty, it would be sensible to tax the flight rather than the passenger.

\section{Taxes on waste and natural resources}

- The landfill tax was introduced in 1996 at rates reflecting estimates of the marginal external cost of landfill. Increases in the rate since 1999 appear to have been motivated by the need to hit targets set by the 1999 European Landfill Directive rather than being justified by higher external costs.

- More than 80 per cent of municipal waste was landfilled in 1996-97; by 200405, this had fallen to less than 70 per cent. The direct impact of the landfill tax is unclear.

- The aggregates levy may be justified by external costs from aggregates extraction, such as noise, groundwater pollution and loss of habitat. The rate of decline in aggregates extraction has actually slowed since the levy was introduced, but it is not clear what would have happened in its absence.

- Estimates for both the aggregates levy and the climate change levy suggest that the revenue they generate is less than the revenue lost from lower employer National Insurance contributions introduced alongside them to make them 'revenue-neutral'.

\section{Energy taxes}

- Power station emissions of $\mathrm{CO}_{2}$ fell by 29 per cent in the 1990 s but rose by 16 per cent between 1999 and 2005. This reflects a greater use of coal-fired generation in recent years.

- VAT on domestic fuel, currently 5 per cent, may provide incentives to reduce domestic energy consumption and thus emissions. However, it does not change the relative costs of different fuels - better incentives might come from reducing the cost of renewably-generated energy, where environmental impacts are lower.

- VAT on fuel is also regressive and may impact negatively on government targets to reduce fuel poverty amongst vulnerable households.

- The government provides incentives, such as the Warm Front scheme, for households to install energy-saving materials in the home. This provision may be justified by market failures in the energy efficiency market - either an inability to obtain credit to install the materials or the lack of incentives for landlords to install them in tenants' dwellings.

- The climate change levy (CCL) was introduced in 2001 as a tax on energy supplied to business. Taxes are higher on more polluting fuels and zero on fuels from renewable sources. Real-terms receipts have declined since 2002-03 as the tax rate has not been uprated in line with prices.

- A recent report suggests that the CCL will reduce $\mathrm{CO}_{2}$ emissions levels by around 2.3 per cent in 2010. 


\section{CHAPTER 1 Introduction}

A precise definition of what is meant by 'environmental taxes' is hard to come by. The OECD, in its online database of international measures, ${ }^{1}$ suggests that they are 'any compulsory ... payment to general government levied on tax-bases deemed to be of particular environmental relevance'. Typically, they may be thought of as taxes directly on actions or products that are detrimental to the environment, more often than not with the ambition to reduce or control levels of pollution. However, they can encompass a wide range of instruments that have environmental effects that may be secondary to the original design of the measure or where the aim is more resource management than pollution control.

This report aims to summarise the state of play of environmental taxes in 2006 and to begin to look ahead at what might be still to come. We take a broad view of what is meant by environmental taxes to look at a variety of measures currently in force. It is clear that as the debate over environmental emissions of greenhouse gases and other pollutants has intensified over the last decade or so, the range of measures employed by government (both central and local) has also tended to increase. International agreements such as the Kyoto Protocol have provided targets for nation states, and the UK government has published its own internal targets for emissions reductions which have been accompanied by a swathe of new policies being implemented and existing policies adjusted to take a more specific environmental goal into account. Political parties of all colours now seem keen to highlight their green credentials - in 2005, the Chancellor announced a review of the economics of climate change to be headed by Sir Nick Stern, due to report in Autumn 2006, and both major opposition parties have flagged up environmental policies.

In the foreword to HM Treasury (2002), Gordon Brown commented that

... environmental taxes and other economic instruments can play an important role in ensuring that prices reflect environmental cost $\ldots$ and discouraging behaviour that damages the environment.... Of course any Government intervention must be proportionate and well-targeted, and needs to take into account other factors such as distributional effects and business competitiveness ...

In policymaking, using fiscal measures to promote environmental goals must be considered in the light of other government objectives, such as poverty reduction or international competitiveness. An earlier 'Statement of Intent' on environmental taxation (see HM Treasury (1997)), published shortly after the current government came to power, also argued that as well as considering distributional and competition concerns, environmental taxation 'must be well designed, to meet objectives without undesirable side-effects ... [and] must keep deadweight compliance costs to a minimum'.

\footnotetext{
${ }^{1}$ See http://www2.oecd.org/ecoinst/queries/index.htm.
} 
We begin, in Chapter 2, with a discussion of the economics of environmental taxation, looking at the rationale for using taxes to control pollution and discussing the advantages and disadvantages of taxation-based methods as opposed to other methods. Chapter 3 examines the importance of environmental taxes as a source of government revenue over time, comparing trends in the UK with those internationally, and challenges the commonly-held idea that environmental taxes have been growing in importance over the past decade. In Chapter 4, we examine evidence on emissions and emissions sources from the UK, relating them to domestic and international targets for emissions abatement. Again, we compare the UK to other countries in this regard. Our focus then moves in Chapter 5 to individual tax instruments currently in use, focusing on those used in the transport sector, those used to control natural resources and those used in the energy sector. For each measure, we aim to examine its history and motivation, its design and implementation, and evidence on both intended and unintended consequences. We consider not just explicit taxes on particular products or actions that may have environmental consequences, but also the growing use of permit-trading schemes to provide environmental incentives and how existing measures such as VAT have been subtly altered in recent years with environmental aims in mind. Chapter 6 considers some potential future developments in environmental taxation, before Chapter 7 summarises and concludes.

It is important to state clearly what this paper is not designed to be. We are not advocating particular future policies, nor will we be trying to assess how far current policies will take the government towards meeting its existing commitments to reduce emissions. Instead, the aim is to provide an overview of where current policy has taken us. 


\section{CHAPTER 2 The Rationale for Environmental Taxation}

The primary rationale for the use of environmental taxes is the externalities argument. This says that in deciding how much, and in what way, to produce or consume, a polluter will not take into account the costs imposed on society at large from their private actions, meaning that, from a socially optimal point of view, too much pollution will be generated. Environmental taxes may be able to align the private incentives of the polluter with the socially desirable outcome. They will also conform to the so-called 'polluter pays principle' (PPP) whereby the costs of pollution control are paid by the polluter themselves and not by society at large. Taxes of this nature are often called 'Pigouvian' taxes after the work of Pigou (1920), who first looked at means to correct for negative externalities in this way.

It should be noted that, in general, an optimal level of pollution will be above zero. Reducing emissions has a cost and, from an efficiency perspective, emissions should only be reduced to the point where the cost of reducing emissions by one more unit is equal to the benefit to society of so doing.

Figure 2.1

Optimal pollution abatement for a single polluter

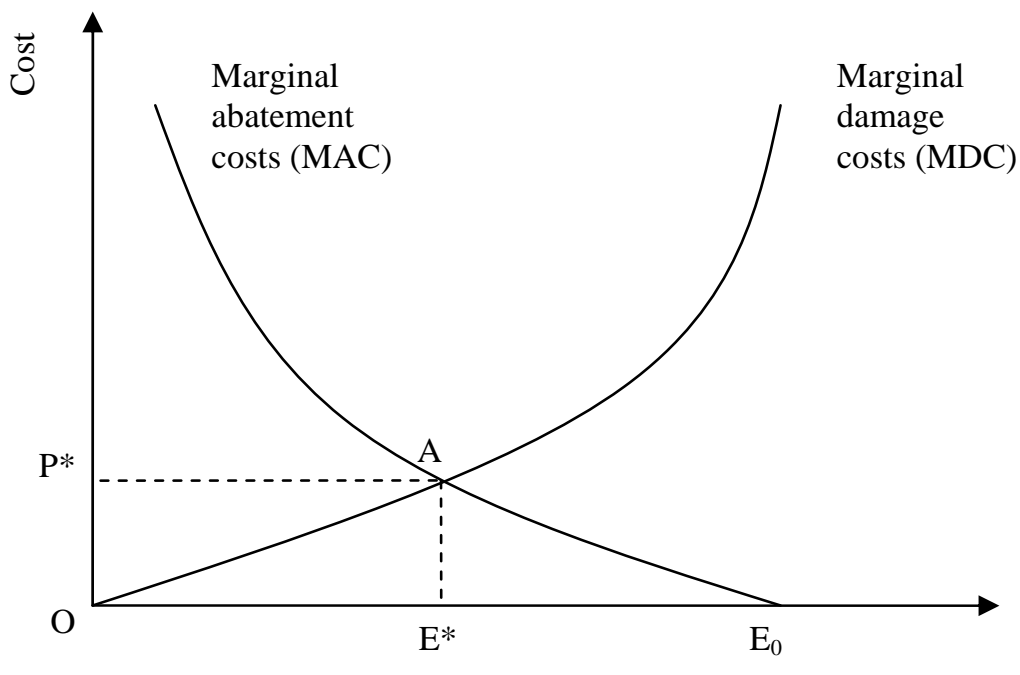

Level of emissions

Figure 2.1 demonstrates a simple version of the externalities argument for a case where there is a single polluter. With no constraints on his behaviour, the polluter would choose a level of emissions $E_{0}$. Each successive unit of pollution reduction (abatement) has a cost shown by the marginal abatement cost (MAC) curve. Typically, we would assume that each unit of abatement would be more costly than the last, since the polluter would choose to do the simplest, least-cost abatement 
first. Thus as abatement rises and emissions fall towards zero, the marginal cost curve rises. The marginal damage cost (MDC) curve shows the external costs for each unit of pollution. Often we might think that damage rises more rapidly the greater the level of emissions. From an efficiency perspective, abatement should occur until the point $\mathrm{E}^{*}$ at which the marginal cost of abatement and the marginal benefit in the form of reduced emissions damage are equated at a value $\mathrm{P}^{*}$. Without intervention, the emission level $\left(\mathrm{E}_{0}\right)$ is too high.

An optimal emissions tax would be set at a rate of $\mathrm{P}^{*}$ for each unit of emissions. This would provide the correct incentives for the polluter to reduce his emissions to $\mathrm{E}^{*}$, since the marginal cost of abating each unit of emissions between $\mathrm{E}_{0}$ and $\mathrm{E}^{*}$ is less than the tax saving he would make by abatement. The polluter would have no incentive to reduce emissions further still towards zero since the MAC for each unit of pollution reduction would be higher than the tax saving he would make. Thus the tax would 'internalise' the external costs of the pollution.

A tax of rate $\mathrm{P}^{*}$ would provide a revenue to the tax authority of the area $\mathrm{P}^{*} \mathrm{OE} * \mathrm{~A}$. This revenue exceeds the total value of the external costs, given by $\mathrm{E}^{*} \mathrm{AO}$. There is no economic rationale for environmental tax revenues to equal total external costs in general. Further, estimates of external costs will typically be estimates of the average external costs rather than the marginal external costs, and there is no economic rationale for setting the tax at the average external cost rate. Efficiency is achieved by setting the tax rate equal to the marginal externality at the optimum level of emissions. Only if externalities do not change with the level of emissions will the average and marginal costs be the same.

However, this need not imply that estimates of the average external costs are unimportant - on the contrary, they can provide useful information for policymaking. In practice, the difference between average and marginal externalities in many cases may well be quite small. Certainly, considering average external costs in policymaking is preferable to making policy without any reference to the scale of the externality at all.

In principle, the government could achieve the optimal outcome by imposing a regulatory requirement on the polluter to reduce emissions to $\mathrm{E}^{*}$, rather than setting a tax of $\mathrm{P}^{*}{ }^{2}$ Below, we discuss some of the advantages and disadvantages of using taxes rather than such a 'command and control' (CAC) approach to environmental regulation.

\subsection{Pros and cons of using environmental taxes}

For a full discussion of the advantages and disadvantages of market-based mechanisms such as taxes to control emissions, chapters 2 and 3 of Smith (1995) provide a clear summary. We discuss the issues more briefly here.

\subsubsection{Efficiency}

Where there is more than one polluter, and where they differ in their marginal abatement costs, an emissions tax will provide incentives for the lowest-cost abaters

${ }^{2}$ Or using an emissions trading scheme with an allowance of $E^{\star}$ permits given to the polluter. 
to reduce emissions more than the highest-cost abaters, such that the total abatement will be achieved more cheaply than if a uniform standard were set for each polluter. Firms will not necessarily be able to reduce emissions at the same marginal costs if, say, technology differs across them.

Although it is not necessary to impose a uniform emissions standard under CAC regulation (regulators could require low-cost abaters to reduce emissions by more than high-cost abaters), the authorities would require a great deal of information in order to design anything other than a uniform system. By contrast, a tax will lead to firms self-selecting as high- or low-cost abaters. In addition, the only way that a regulator would gain information about firms' relative abatement costs would be to talk to the firms themselves, which leads to the danger of 'regulatory capture' whereby the firms could limit the information they provide in order to minimise the amount of abatement they are required to do.

Apart from this 'static efficiency', a tax may provide dynamic incentives for firms to reduce abatement costs in order to be able to reduce emissions, and thus tax payments, further. No such incentives are provided by a CAC approach where, once the standard for emissions has been met, there is no need to reduce them further.

\subsubsection{Revenue-raising and the 'double dividend'}

Emissions taxes will generate revenues which can be used to fund government expenditure, whereas CAC policies will not - indeed, there will be a net cost to the exchequer through administration and enforcement costs (though these will also be present with taxes).

Some commentators have argued that revenues from environmental taxes could be used to reduce other, more distortionary taxes on labour (see, for example, Terkla (1984)). This so-called 'revenue-recycling effect' generates what has been popularly known as a 'double dividend' of reduced environmental damage and increased efficiency of the tax system, all at zero net cost to the exchequer. If a double dividend meant that environmental taxes could be implemented at zero or even negative overall economic cost, then it would provide a justification for their introduction over and above the externalities argument.

However, there is considerable controversy over this view. The major counterargument was the so-called 'tax-interaction effect' (see, for example, Bovenberg and de Mooij (1994)) - environmental taxes that, for example, raise the price of energy (such as a carbon tax or climate change levy) would typically raise product prices throughout the economy as energy is a key input into most production. This reduces real wages and thus labour supply in a competitive economy.

Recent work has examined the relative importance of the revenue-recycling and tax-interaction effects under various different assumptions to try to assess the circumstances under which a double dividend could arise. A relatively nontechnical summary of some of the arguments can be found in Parry (1998).

\subsubsection{Non-uniformities}

Emissions may vary in their effects either across time or across locations. Efficiency would require tax rates to vary too - using a uniform tax for all polluters would mean some pay too much relative to the external costs they generate and others too 
little. A similar problem would exist with a CAC system as well. In principle, it would be possible to design a tax system where the rate varied across space or time to take account of these differences. Since most emissions will have variable effects, a simple single-rate emissions tax may still exhibit inefficiencies.

\subsubsection{Uncertainty}

An environmental tax may not generate the correct level of abatement if there is uncertainty over the MDC/MAC schedules or over the extent to which polluters will respond. This may require the government to adjust tax rates in order to get the desired outcome, and will mean inefficiencies will persist until this is achieved.

Authorities may not always be concerned to hit the exactly socially optimal level of emissions in the economic efficiency sense we have discussed so far. In many cases, countries will have explicit emissions targets or objectives to hit (which can be traced to the work of Baumol and Oates (1971)), and so setting a CAC policy to obtain these targets will provide certainty over the outcome which a tax will not. There is then a trade-off between the risk of missing the target and having excess emissions from using a tax approach, at least until the rates are adequately adjusted, and the inefficiencies inherent in using a CAC approach to hit a target which may not quite be economically optimal. If the penalties for missing a target are severe, governments may prefer the certainty of a CAC system.

\subsubsection{Distributional implications}

The use of environmental taxes that hit domestic consumers is often controversial because of concerns that they impact more severely on the poor than on the rich that is, they are thought to be regressive. Even environmental taxes that are ostensibly levied on firms are often passed on to consumers in the form of higher goods prices. Such concerns are voiced with taxes such as petrol duties and VAT on domestic fuel, amongst others. We will explore this issue further throughout the report when such concerns seem to be particularly severe.

\subsection{What should be taxed?}

From an economic efficiency point of view, if what we are concerned about is the level of emissions of a particular pollutant, the ideal tax would be levied directly on that emissions level. However, in many cases, this might not be possible, either because the level of emissions is not observable at all or because the costs involved in calculating and collecting such information are extremely high.

A common alternative is therefore to tax emissions indirectly by instead levying the charge on the level of output or consumption of a particular good which is much more easily observed and will be positively related to the amount of emissions generated by the production or consumption of the good. One example is taxes on petrol; another is taxes on the volume of landfill. This method will be beneficial if the administration, enforcement and implementation costs of such an indirect tax are not outweighed by any efficiency losses from the correlation between output and emissions being imperfect. 
Box 2.1

Emissions trading schemes

Although the bulk of this report will focus on taxation measures, it is worth discussing the growing importance and use of emissions trading schemes in the UK and beyond as a means of emissions control. Throughout this report, discussion of trading schemes will be presented in boxes.

The basic idea of an emissions trading scheme is that participants are allocated permits which give them the right to generate a certain level of emissions. If they reduce emissions below their allocation, they can sell their excess permits to other participants who are struggling to reduce emissions. This means that the most efficient abaters can trade with the least efficient abaters, with the price of the permit reflecting the marginal cost of a unit of pollution abatement. Efficient abaters will do more abatement and receive payment for the excess; inefficient abaters will do less abatement and pay for the privilege. A 'market' for pollution is created where none existed before, and the price of permits will fluctuate according to the supply of and demand for them.

Superficially, trading schemes appear to be a very different way from taxation measures to tackle environmental damage, but in practice there are strong similarities between the two. There is a 'price' of pollution set either by the tax rate or by the price of the permit, and abatement will occur up to the point where its marginal cost equates to this price. The crucial difference between the two, as discussed in the seminal paper by Weitzman (1974), is over the source of the uncertainty. In a taxation-based system, the 'price' is certain, fixed at the tax rate, but the level of abatement this will generate is uncertain if the abatement costs are not known precisely. In a permit-based system, the total level of abatement is known as it is fixed by the number of permits issued, but the total cost of this abatement is unknown since it will be determined by the traded price of permits. However, under a trading scheme, the required abatement ought to be achieved at minimum cost, unless the market for permits is uncompetitive (for example, if one firm has a large surplus of permits to sell, it may create a monopsony).

Schemes will differ in exactly how they operate. For example, the initial permits may be given to participants for free ('grandfathered') based on historical or projected emissions, or auctioned with higher bidders receiving more permits. Economists typically prefer the idea that permits are auctioned rather than simply given away. One danger of grandfathering permits is that it gives incumbent firms an advantage since new firms will have to purchase permits from existing firms (though a reserve of permits could be held back for new entrants, as in the EU scheme described below). Another possibility is that firms will have better information about their emissions than governments or environmental regulators, and as such will be able to claim a higher number of permits by overstating prior emissions or underestimating future abatement. Under an auction system, firms that believe they can reduce emissions easily in the future will bid for a lower number of permits and those that believe they will not be able to abate will bid for a higher number of permits. Another advantage of an auction-based system is that it generates revenue - this allows the possibility of a 'double dividend', whereas with grandfathered permits the lack of revenue means any 'tax-interaction effect' from higher product prices that result from firms having to reduce emissions cannot be 
offset by a 'revenue-recycling effect' (see Parry (2003)). Despite these arguments, grandfathered permits have dominated trading schemes thus far (where they have existed, auctions have tended to be for a small percentage of the total number of permits). Stavins (1998) argues that this is because freely allocated permits are easier to supply since the costs are not upfront and are therefore less visible to industry (and consumers, who would bear the ultimate burden), which might make schemes more politically acceptable. In addition, grandfathering allows legislators to exert political control over the distributional effects of trading schemes (allowing certain firms, regions or industries to be favoured).

There has been much experience of emissions trading in the US, notably with the Acid Rain Programme of $\mathrm{SO}_{2}$ trading which began in 1990 as part of the Clean Air Act and aims to reduce $\mathrm{SO}_{2}$ emissions by half between 1980 and 2010. In Chapter 5, we discuss two particular schemes in operation at present in the UK: the UK Emissions Trading Scheme (UK ETS) and the EU Emissions Trading Scheme (EU ETS). These schemes are focused at the corporate level but there would not, in principle, be a reason why similar schemes could not be used at a personal level. For example, motorists could be allocated permits allowing them to drive a certain number of miles per year (which could vary with the fuel efficiency of their car, say). Motorists who drive less could sell part of their quota to motorists wishing to drive more at a price mutually agreeable to both. Clearly, there are practical difficulties with this scheme, but it may be that ways to move towards such a system may be plausible in the future. 


\section{CHAPTER 3 Environmental Tax Revenues}

\subsection{Trends in total revenues}

If environmental taxation is seen as a desirable thing both in terms of economic efficiency (optimal levels of pollution) and as a sensible tax base to reduce other, more distortionary taxes (the 'double dividend'), then one might expect the importance of environmental taxes as a source of government revenue to have increased over time.

However, evidence from both the Office for National Statistics and the OECD suggests that both nationally and internationally this is not the case. The share of tax revenue coming from environmentally-related sources has, if anything, declined slightly over the past decade, as have environmental tax revenues as a share of national income.

Figure 3.1 shows total real-terms tax revenues from environmental sources in the UK between 1993 and 2004, and in each year the breakdown of these revenues amongst four key taxation types - fuel duties and associated VAT, other energy taxes (including climate change levy and predecessors), vehicle excise duty and other taxes (including air passenger duty, landfill tax and aggregates levy). Table 3.1 then breaks down the 2004 values by tax and includes revenues for 2004 from other environmental taxes considered in this report but not included in Figure 3.1.

Figure 3.1

Environmental tax revenue and sources
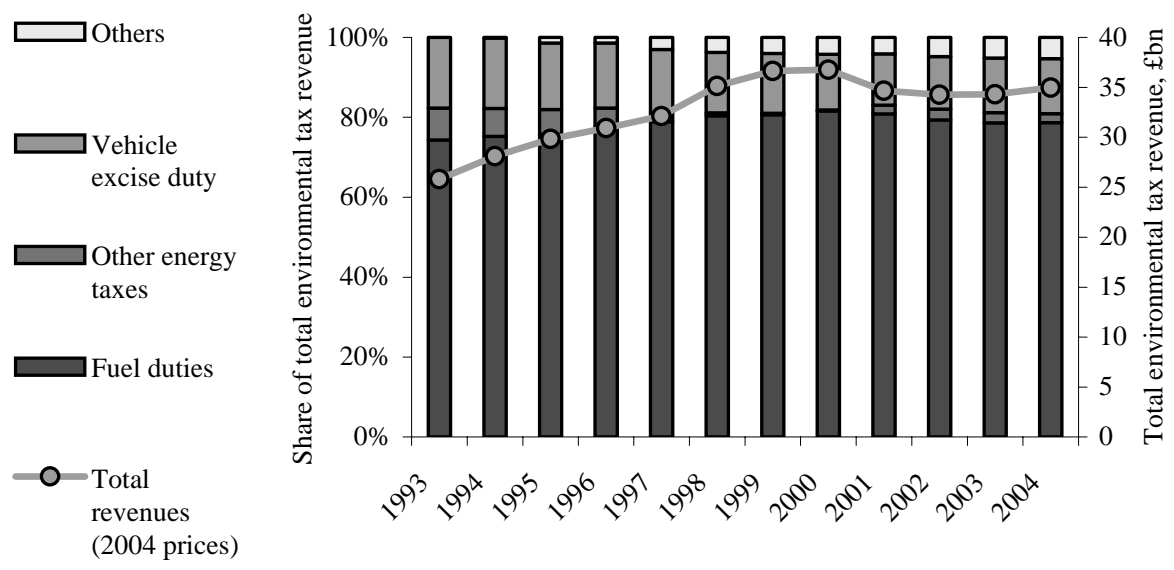

Sources: Office for National Statistics, 2005; author's calculations. 
Table 3.1

Environmental tax revenues by source, 2004

\begin{tabular}{l|r}
\hline Tax & Revenue (2004), Em \\
\hline Included in Figure 3.1 & 23,412 \\
Fuel duty & 4,800 \\
Vehicle excise duty & 4,097 \\
VAT on motor fuel & 856 \\
Air passenger duty & 768 \\
Climate change levy & 674 \\
Landfill tax & 328 \\
Aggregates levy & \\
Not included in Figure 3.1 & \\
Taxation of company cars & \\
VAT on domestic fuel & 1,900 (estimated, 2004-05) \\
Water abstraction charges & 800 (estimated, 2005-06) \\
\hline
\end{tabular}

Notes: Water abstraction charges are designed to cover the cost of water resource management, estimated at $£ 128$ million in 2006-07. Estimates of revenue from VAT on domestic fuel are made from HM Treasury (2005) - see Section 5.3.

Sources: Office for National Statistics, 2005; author's calculations.

Figure 3.2

Environmental tax revenue as a share of total tax revenue and GDP

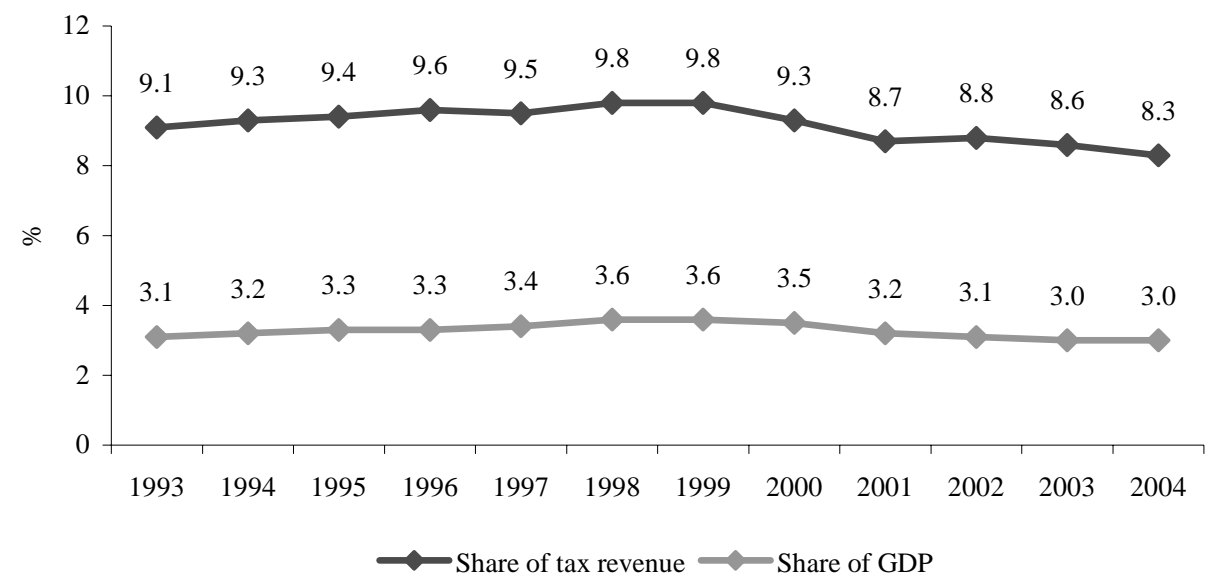

Sources: Office for National Statistics, 2005; author's calculations. 
Figure 3.2 shows the total tax take from environmental sources each year as a percentage of both total tax revenue and GDP.

We can see that total real-terms environmental tax revenues peaked in 2000 at just under £36.8 billion, though as a share of GDP and total revenues environmental taxes peaked a year earlier; in 1999, environmental taxes represented 9.8 per cent of all tax revenue and 3.6 per cent of national income. Since then, real-terms total revenues have declined, to $£ 35.0$ billion in 2004 . This represented just 8.3 per cent of total revenues, the smallest value since this series began, and 3 per cent of national income.

This might be explained by the fact that environmental taxes are not explicitly designed, at least in principle, to raise revenue; rather, they are designed to affect behaviour. If this is the case, then as pollution levels fall, so too will tax revenues. However, as Figure 4.1 below demonstrates, UK greenhouse gas emissions have, if anything, risen over the past few years. The key factor behind the decline in the relative importance of environmental taxes after 1999 was the decision to abandon the fuel duty 'escalator' (see Section 5.1) which saw fuel duties rise in real terms each year. Thus real-terms fuel duties and associated VAT (2004 prices) rose from $£ 19.2$ billion in 1993 to $£ 30.0$ billion by 1999, an increase of 56 per cent; in 2004, real duties were $£ 27.5$ billion, 8 per cent lower than the 2000 value.

The major UK environmental taxes are fuel duty (and associated VAT) and vehicle excise duty. Together, these account for more than 90 per cent of the revenues from taxes included in Figure 3.1, and around 85 per cent of revenue from all taxes considered in Table 3.1. Although the distributional consequences of environmental taxes are often thought to be significant, it is clear that most environmental taxes are too small relative to the rest of the tax and benefit system to have significant distributional concerns. Our focus on the distributional effects of environmental taxes will therefore be confined to fuel duty, vehicle excise duty and VAT on domestic fuel - in the last case, not because the amounts raised are very large, but because distributional effects were an integral part of the debate around its introduction and subsequent lowering.

Another important point to make is that, even if revenues from environmental taxes have fallen as a share of GDP and total tax take, this need not imply that the tax system is being used less to meet environmental ends. As we will see in later sections, although the familiar idea of an 'environmental tax' is one that raises the price of certain actions and generates revenue, there are other ways to use the tax system to provide environmental incentives which may have a relatively negligible, or even negative, fiscal impact. These include variable rates of VAT and methods of promoting income tax offsets for environmental schemes, for example (see Section 5.3 on energy taxes for specific examples). Such things would not show up in the figures here but would still represent examples of using the tax system to promote environmental ends. In addition, environmental incentives within existing tax measures can be sharpened (such as changing the rates of vehicle excise duty to reflect emissions rather than charging based on engine size; see Section 5.1). Finally, government policy may be moving away from explicitly using revenueraising taxes as the major way of generating environmental outcomes, and instead looking more towards systems of tradable permits in a range of cases, which we will discuss below as they arise. 


\subsection{Who pays environmental taxes in the UK?}

Figures published by the Office for National Statistics (ONS) for 2002 environmental tax revenues attempted to break down who was responsible for paying them into 13 sectors: households, industry (broken into 11 industry types) and the rest of the world. Although these data are not available for more recent years at present, it is unlikely that the balance has shifted dramatically since 2002.

In 2002, £32.7 billion was raised from environmental taxes in 2002 prices. Of this, around $£ 17.2$ billion, or just over half, was directly paid by households: around $£ 13.1$ billion on domestic energy and $£ 4$ billion on transport. Businesses in the transport and communication sector paid around $£ 6.2$ billion, those in the wholesale and retail trade sector paid around $£ 2.3$ billion and those in the manufacturing sector around £2.1 billion. Figure 3.3 breaks down the total revenue across the 13 sectors studied by the ONS. Of course, the final incidence of all taxes is usually the household sector as goods prices rise as a result of taxes levied on firms.

\section{Figure 3.3}

Source of payments of $£ 32.7$ billion in environmental taxes by sector, 2002

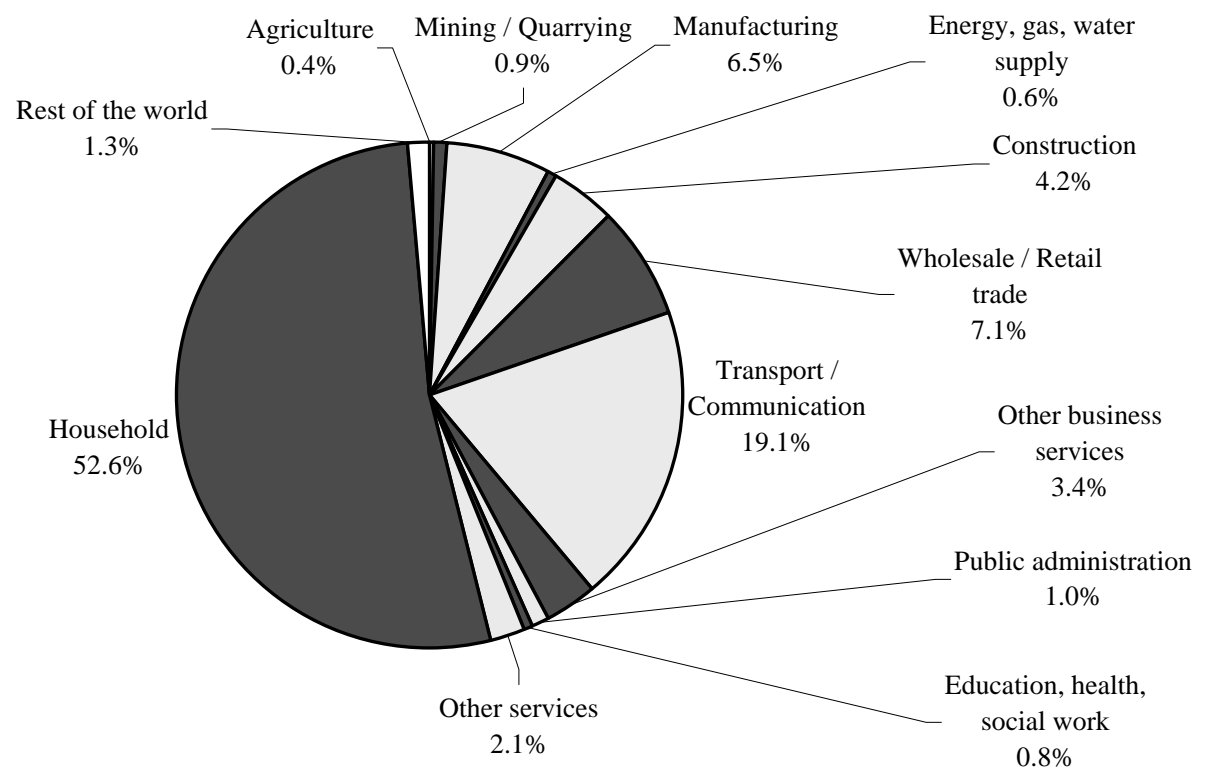

Source: Office for National Statistics, 2005. 


\subsection{How does the UK compare internationally?}

Data from the OECD (2006) give us some insight into the revenues from environmental taxes as a share of total national tax revenue and national income in each of the major economies between 1994 and 2003. Figures 3.4 and 3.5 show these for selected OECD economies for those two dates, giving us changes over almost a decade.

As the graphs suggest, environmental taxes have contributed a smaller share of revenue and represented a smaller share of GDP in many industrialised countries since the mid-1990s, though this is not universally the case. There were substantial increases in the share of tax revenue from environmental taxes in Turkey, Denmark, Finland, Austria and Poland, with large reductions seen in Mexico, Korea, Norway, Greece, Italy and Australia. The UK typically relies more on environmental sources for tax revenue than other OECD and EU economies, ${ }^{3}$ in particular the United States which had the lowest revenue to GDP ratio of all the OECD in 2001.

Figure 3.4

Environmental tax revenues as a share of national income

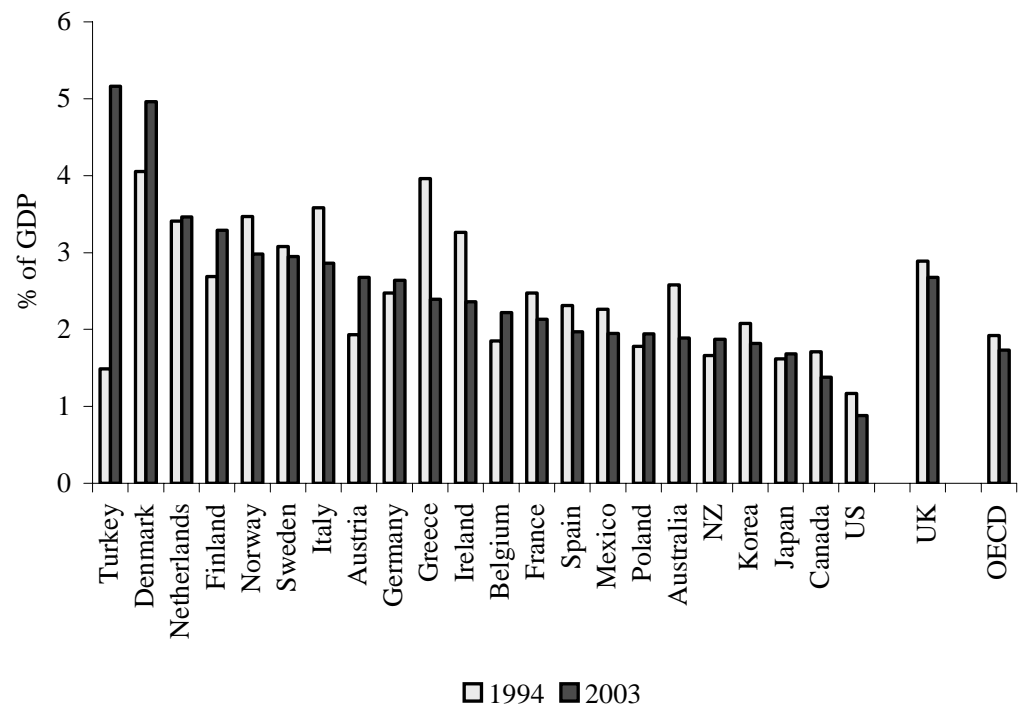

Notes: Australia figures are for 1994 and 2002 (latest available). OECD figures are weighted averages. Source: OECD, 2006.

\footnotetext{
${ }^{3}$ Note that the OECD figures and ONS figures for the UK do not match exactly: the ONS figures typically put the share of tax revenues from environmental taxes around 1 percentage point higher than the OECD figures. This is due to the choice of which taxes to include under the heading 'environmental'. The OECD figures do not include VAT on fuel duties as an environmental tax whereas the ONS figures do; this and other minor differences account for the apparent discrepancy. Note that neither includes VAT on domestic fuel as an environmental tax, nor water abstraction charges.
} 
Figure 3.5

Environmental tax revenues as a share of total tax revenue

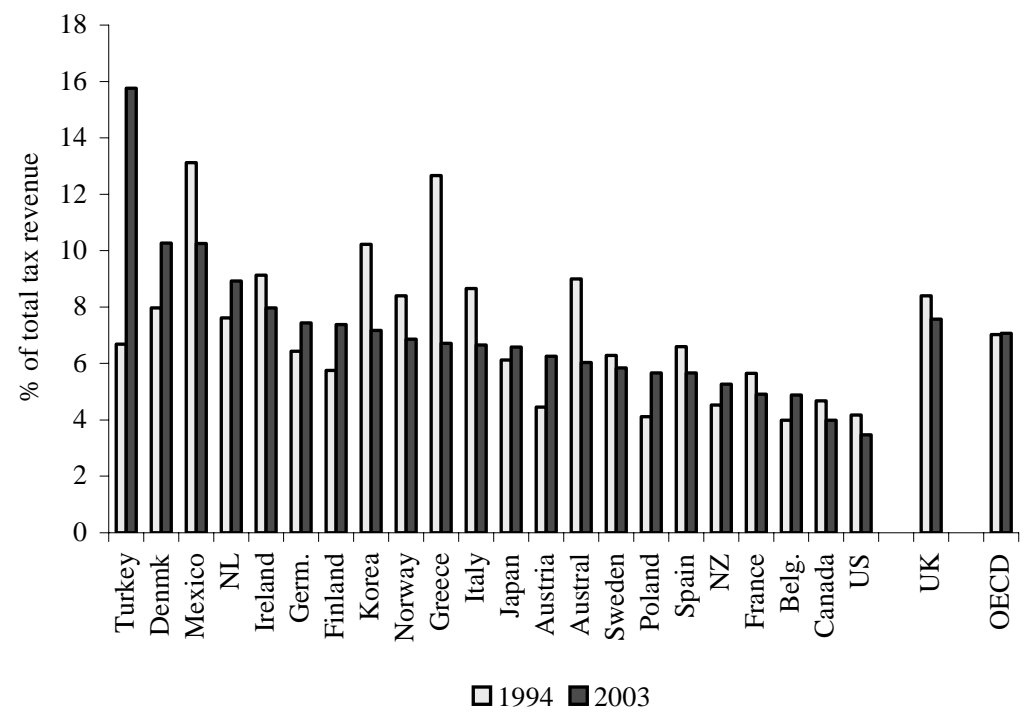

Notes: Australia figures are for 1994 and 2002 (latest available). OECD figures are weighted averages. Source: OECD, 2006. 


\section{CHAPTER 4 \\ A History of Emissions and Emissions Targeting in the UK}

\subsection{Trends in UK emissions}

The UK is one of the signatories of the 1997 Kyoto Protocol. The treaty gave the UK and all other EU countries a target to reduce total greenhouse gas emissions ${ }^{4}$ compared with their 1990 level by 8 per cent by 2008-12..$^{5}$ In 2002, the EU announced that Member States would meet that target as a collective, and that some states would be allowed to reduce emissions by less than others whilst maintaining on average a reduction of 8 per cent across the whole EU. ${ }^{6}$ The UK was set a target to reduce emissions by 12.5 per cent by 2008-12. Further to this international target, the UK adopted its own domestic target for $\mathrm{CO}_{2}$ emissions in November 2000 as part of the 'climate change programme'. The target called for a reduction in $\mathrm{CO}_{2}$ emissions of 20 per cent by 2010 compared with the 1990 level. In 2003, a DTI White Paper, Our Energy Future - Creating a Low Carbon Economy, ${ }^{8}$ further added a target to reduce $\mathrm{CO}_{2}$ emissions by 60 per cent by 2050, to around 65 million tonnes of carbon (MtC).

Figures 4.1 and 4.2 show total greenhouse gas emissions and $\mathrm{CO}_{2}$ emissions since 1990, compared with progress that would need to be made to hit Kyoto and domestic targets for the two in 2010. From a 1990 baseline of just over $210 \mathrm{MtC}$ of emissions, the UK met its Kyoto target of $186 \mathrm{MtC}$ of emissions as early as 1999, since when total emissions have stabilised just below the target level. According to DEFRA, around one-half of the reduction in emissions in the UK can be attributed to energy liberalisation leading to the increased use of gas in UK electricity generation $^{9}$ (popularly known as the 'dash for gas'). A detailed look at the UK figures shows the largest greenhouse gas emission reductions between 1990 and 2002 occurred for PFCs (73 per cent), $\mathrm{CH}_{4}$ (48 per cent) and $\mathrm{N}_{2} \mathrm{O}$ (41 per cent).

Figures from the European Environment Agency (2005) show that in 2003, Luxembourg, the UK, Sweden, Germany, France and the Netherlands were the only EU-15 countries on course to meet their targets under Kyoto, the other nine nations being behind target.

\footnotetext{
${ }^{4}$ The gases included in the treaty are carbon dioxide $\left(\mathrm{CO}_{2}\right)$, methane $\left(\mathrm{CH}_{4}\right)$, nitrous oxide $\left(\mathrm{N}_{2} \mathrm{O}\right)$, hydrofluorocarbons (HFCs), perfluorocarbons (PFCs) and sulphur hexafluoride $\left(\mathrm{SF}_{6}\right) . \mathrm{CO}_{2}$ is by far the most important of these, accounting for around 86 per cent of the total carbon emissions from these sources in the UK in 2003.

${ }^{5}$ See annex B of http://unfccc.int/resource/docs/convkp/kpeng.pdf.

${ }_{7}^{6}$ See annex II of http://europa.eu.int/eur-lex/pri/en/oj/dat/2002// 130// 13020020515en00010020.pdf.

7 http://www.defra.gov.uk/environment/climatechange/pubs/ukccp/2000/index.htm.

8 Department for Trade and Industry, 2003.

${ }^{9}$ See http://www.defra.gov.uk/environment/statistics/globatmos/kf/gakf18.htm.
} 
Figure 4.1

UK greenhouse gas emissions relative to Kyoto target

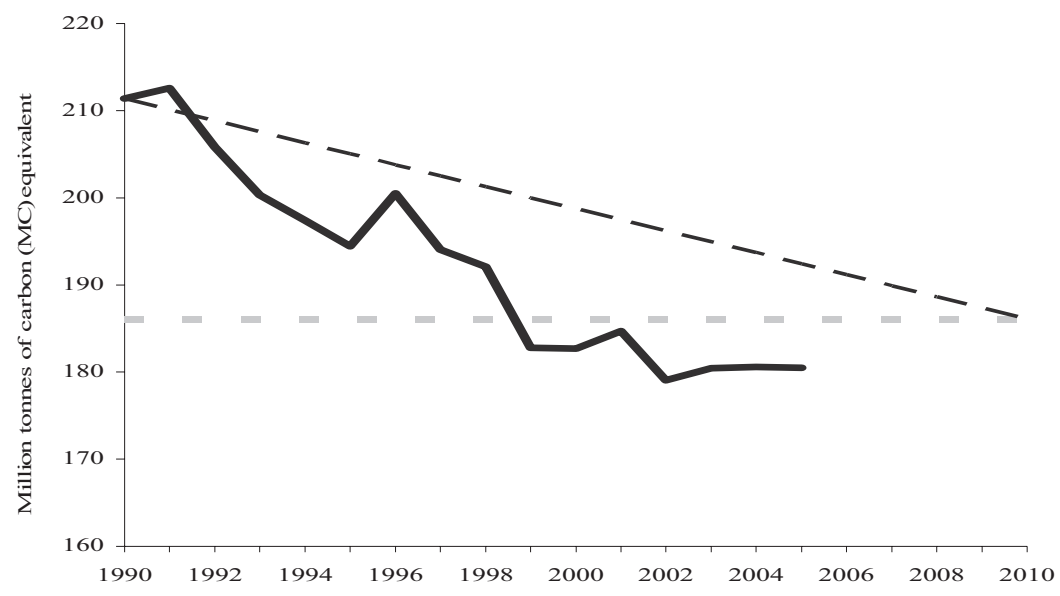

Notes: Graph shows estimated total emissions of greenhouse gases in million tonnes of carbon equivalent. 12 tonnes of carbon is approximately 44 tonnes of $\mathrm{CO}_{2}$. Figures for 2005 are preliminary. The target path assumes that the 2008-12 target is hit in 2010 .

Source: Department for Environment, Food and Rural Affairs, 2006.

Figure 4.2

UK $\mathrm{CO}_{2}$ emissions relative to domestic target

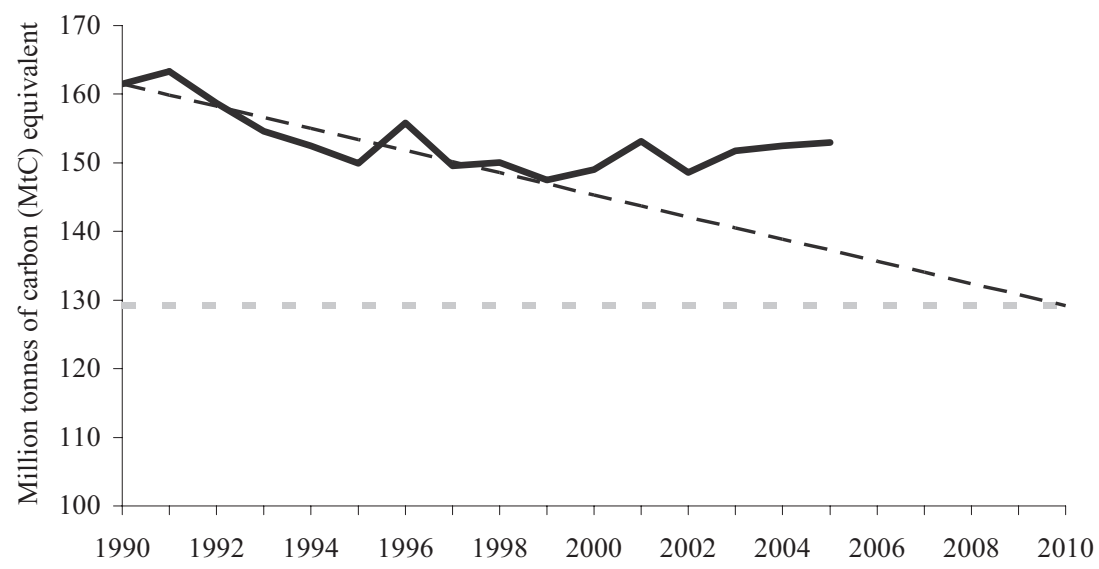

Notes: Graph shows estimated total emissions of $\mathrm{CO}_{2}$ in million tonnes of carbon equivalent. 12 tonnes of carbon is approximately 44 tonnes of $\mathrm{CO}_{2}$. Figures for 2005 are preliminary. The target path assumes that the 2008-12 target is hit in 2010.

Source: Department for Environment, Food and Rural Affairs, 2006. 
The UK is doing less well towards hitting its domestic $\mathrm{CO}_{2}$ reduction target for 2010. From a 1990 baseline of $161 \mathrm{MtC}$ of emissions, a 20 per cent reduction in 2010 would imply a level of 129 MtC. To achieve this linearly would require an emissions reduction of around 1.1 per cent per year; up to around 1999 this was broadly on course, but since 1999 emissions have actually risen, from $148 \mathrm{MtC}$ to $153 \mathrm{MtC}$ in 2005. The UK is now around 11 per cent above a linear target - to reduce emissions to $129 \mathrm{MtC}$ by 2010 as required will need annual reductions of 3.3 per cent. To achieve its 60 per cent reduction target to $65 \mathrm{MtC}$ by 2050, emissions would have to fall by 1.5 per cent per year between 1990 and 2050, or by 1.9 per cent per year from 2005 levels.

Where do UK emissions come from? Figure 4.3 shows total $\mathrm{CO}_{2}$ emissions by end-user between 1970 and 2003. ${ }^{10}$ The bulk of emissions come from industrial, residential and transport users. Whilst total emissions have declined, the contribution from different sources has varied. Table 4.1 shows the relative change in emissions from the five sources in the graph between 1970 and 2003 and between 1990 (the Kyoto and domestic target baseline year) and 2003. All sectors other than transport have seen declines since 1970 and further declines since 1990. The largest declines before the target baseline occurred in industrial and residential sources; since the baseline year, residential emissions have barely changed but commercial emissions have declined sharply and industrial emissions have continued to fall.

The rise in transport emissions has occurred because an increase in the volume of traffic has offset a rise in the efficiency of vehicles (see Section 5.1). In 1970

Figure 4.3

End-user sources of UK $\mathrm{CO}_{2}$ emissions

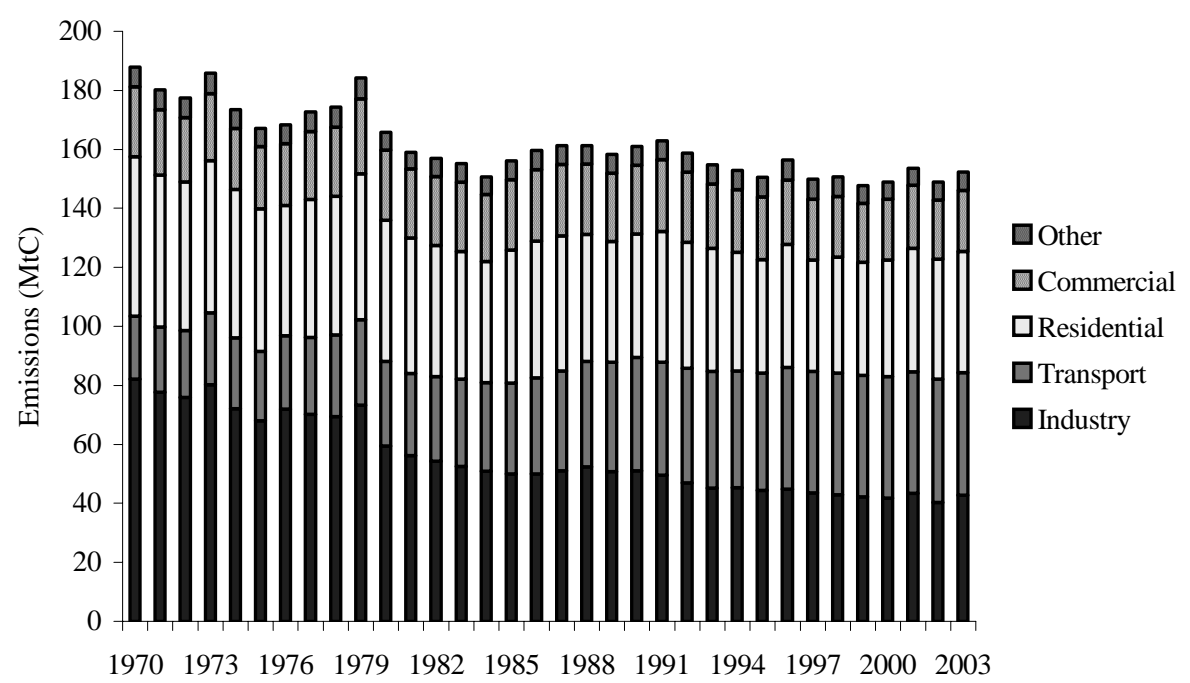

Source: Department for Environment, Food and Rural Affairs, 2005.

${ }^{10}$ Note that the figures do not match those in earlier graphs exactly as values here include $\mathrm{CO}_{2}$ removals. 
Table 4.1

Change in $\mathrm{CO}_{2}$ emissions by source

\begin{tabular}{l|rrr}
\hline Source & $\begin{array}{r}\text { Change } \\
\text { 1970-2003 }\end{array}$ & $\begin{array}{r}\text { Change } \\
\mathbf{1 9 7 0 - 1 9 9 0}\end{array}$ & $\begin{array}{r}\text { Change } \\
\mathbf{1 9 9 0 - 2 0 0 3}\end{array}$ \\
\hline Industry & $-48 \%$ & $-38 \%$ & $-17 \%$ \\
Transport & $+94 \%$ & $+80 \%$ & $+8 \%$ \\
Residential & $-24 \%$ & $-23 \%$ & $-1 \%$ \\
Commercial & $-14 \%$ & $-2 \%$ & $-12 \%$ \\
Other & $-6 \%$ & $-4 \%$ & $-2 \%$ \\
\hline
\end{tabular}

Source: Department for Environment, Food and Rural Affairs, 2005.

transport ${ }^{11}$ accounted for just 11.4 per cent of total $\mathrm{CO}_{2}$ emissions, but by 2003 it had become the second biggest source, at 27.3 per cent compared with 28.1 per cent from industry. The share coming from industry fell from 43.7 per cent over the same period. The share from residential users has been fairly flat, at around 25-30 per cent over the whole period, whilst the share from commercial sources has also been roughly constant, at 12-15 per cent. Other sources account for less than 5 per cent of the total in every year.

Figure 4.4

Consumption-based patterns of emissions, 2002

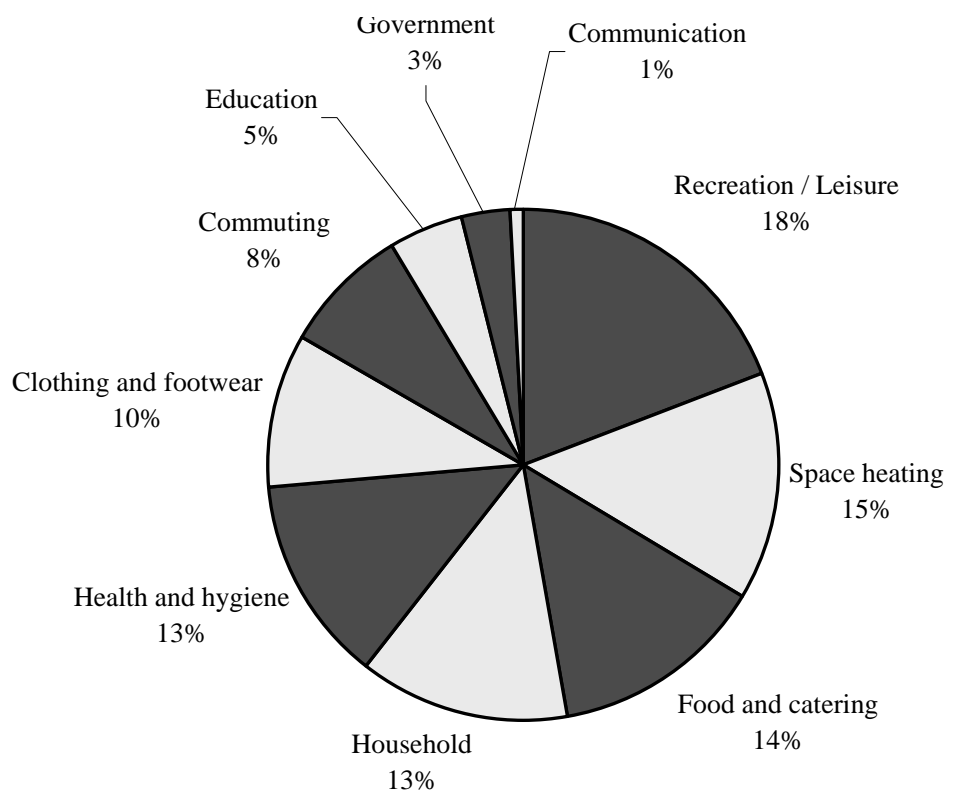

Source: Carbon Trust, 2006.

\footnotetext{
${ }^{11}$ Includes public as well as private transport. In 2003, road transport accounted for $38.3 \mathrm{MtC}$ emissions and other transport 3.3 MtC emissions, including 1.5 MtC from railways, 1.1 MtC from water and 0.7 MtC from domestic aviation.
} 
Of course, it is consumer demand which drives industrial emissions. Work by the Carbon Trust (2006) attempted to reallocate industrial and commercial emissions to the final consumer needs they were meeting. Thus, for example, emissions from the production of metals, glass, power and transportation needed to produce a TV set could be allocated to a 'leisure' category of consumer demand. Figure 4.4 shows how a total emission of $165.4 \mathrm{MtC}$ in $2002^{12}$ was reallocated to consumption demands.

\subsection{The UK in international perspective}

How do trends in UK emissions compare with those internationally? Although the $\mathrm{UK}$, as a relatively large, industrialised economy, is responsible for a not insubstantial amount of total global emissions, the impact of, say, global warming depends on total world emissions - thus the need for international agreements such as Kyoto. Figure 4.5 shows, for eight industrialised nations and China, an index of $\mathrm{CO}_{2}$ emissions relative to their 1990 levels in each country. Of the nine shown, only the UK and Germany had reduced total $\mathrm{CO}_{2}$ emissions below their 1990 levels by 2002. Of the OECD economies, the largest increases occurred in Australia, Canada,

Figure 4.5

Indexed trends in global $\mathrm{CO}_{2}$ emissions

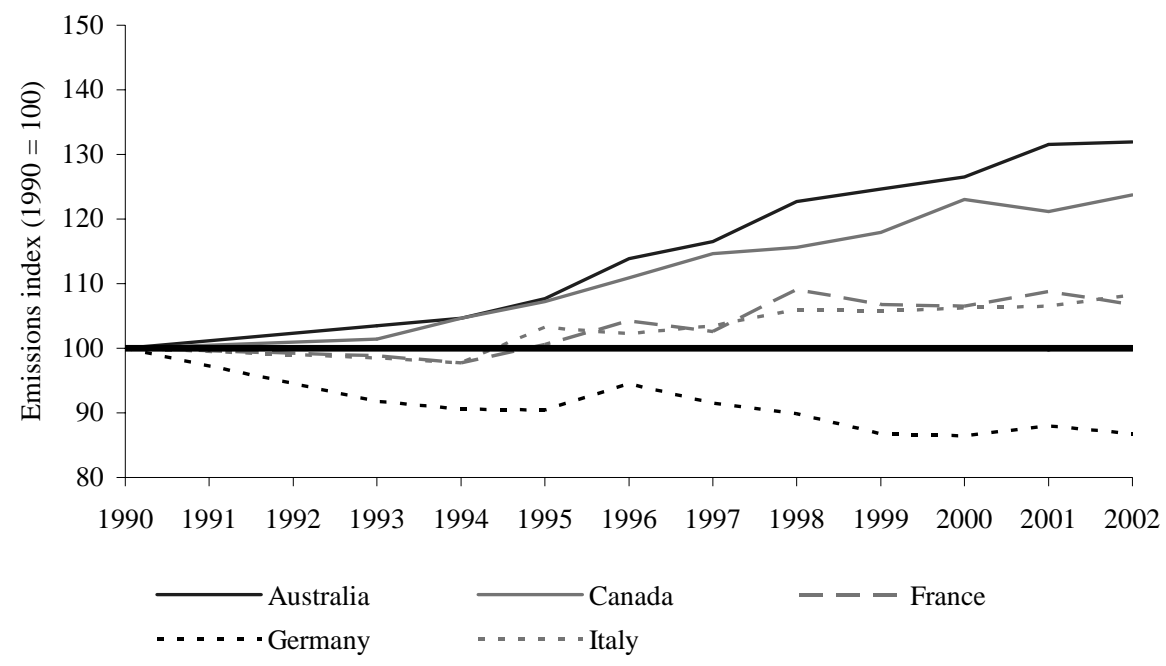

Continues on next page

\footnotetext{
12 Note that in Figure 4.3 above, total emissions for 2002 amount to $148.9 \mathrm{MtC}$. These figures are from DEFRA and are based on UK production rather than UK consumption. This implies that the carbon associated with UK imports exceeds the carbon associated with UK exports - that is, the UK is a net importer of carbon emissions. See page 22 of Carbon Trust (2006) for a fuller analysis.
} 
Figure 4.5 continued

Indexed trends in global $\mathrm{CO}_{2}$ emissions

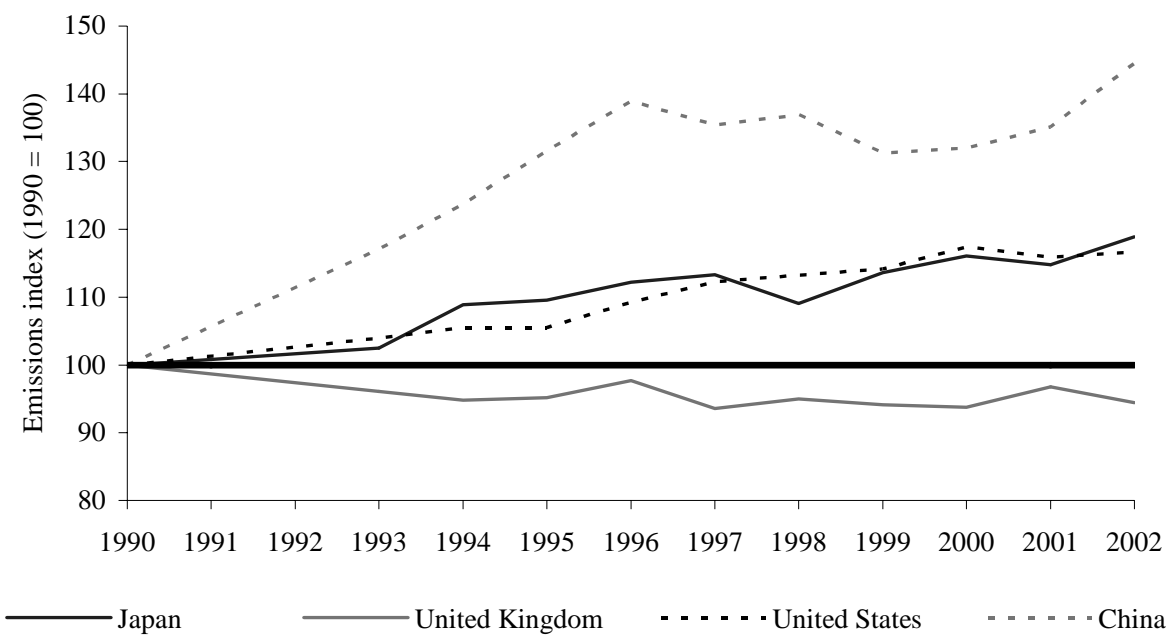

Source: OECD, 2005.

Japan and the US where emissions rose by around 20-30 per cent. ${ }^{13}$ The largest increase came from China, where emissions were around 45 per cent higher in 2002 than in 1990. Global emissions were around 16 per cent higher in 2002 than in 1990.

\footnotetext{
${ }^{13}$ Note that under the Kyoto Agreement, Australia was allowed to increase emissions relative to their 1990
} level by 8 per cent. 


\section{CHAPTER 5 \\ Green Taxes and Other Instruments Currently in Use in the UK}

This chapter will discuss each tax instrument currently used in the UK. We will provide for each instrument some history and background and details of how it operates. The aim will be to comment on each tax in terms of its design and other issues, and where relevant we will frame this discussion in terms of one or all of the following:

- evidence about revenues from the tax and any distributional implications where these seem particularly important;

- evidence about the effectiveness of the tax in terms of meeting stated aims and other, perhaps unintended, consequences;

- comment on the likely future direction of the tax.

We break this chapter down into three sections grouping taxes together under some common theme:

- transport taxes (Section 5.1);

- resource taxes (Section 5.2);

- energy taxes (Section 5.3).

We will then turn in Chapter 6 to possible future developments in environmental taxation, in particular new taxes that might be introduced on the domestic sector and changes to transport taxes. First, though, we discuss in Box 5.1 two emissions trading schemes currently operating in the UK.

\section{Box 5.1}

\section{Existing emissions trading schemes}

\section{UK Emissions Trading Scheme}

The UK ETS began operation in April 2002 and at the time represented the largest such scheme operating anywhere in the world. It is scheduled to run until the end of 2006.

The scheme provides incentives for companies to reduce greenhouse gas emissions by providing payments worth up to $£ 215$ million if targets are met. The UK ETS is open to two groups: 'direct participants' (DPs) and 'climate change agreement participants' (CCAPs). The first group consists of companies that took part in an initial auction to establish targets for emissions reductions in exchange for incentive payments. The second group comprises companies that already had agreements to reduce energy use in exchange for a reduction in their climate change levy payments (see Section 5.3). Although CCAPs are not eligible for extra incentive payments, they can still buy and sell permits in order to meet their preagreed emissions targets. 
DPs take part in the UK ETS voluntarily. ${ }^{\text {a }}$ The auction to determine targets for emissions reductions (in terms of million tonnes of carbon dioxide equivalent $\left(\mathrm{tCO}_{2} \mathrm{e}\right)$ ) took place in March 2002. The auction was known as a 'descending clock' auction. The government announced a payment price per tonne of emissions abatement that would be paid under the incentive scheme. The DPs then 'bid' a total abatement level they would be willing to achieve at that price. The price was then reduced until the total cost of the incentive payments (given by multiplying total bid abatement by the price) was less than $£ 215$ million. The final result saw an incentive payment of $£ 53.37$ per $\mathrm{tCO}_{2} \mathrm{e}$ agreed, and a total abatement of 4.03 million $\mathrm{tCO}_{2} \mathrm{e}$ at that price. The largest agreed target was for Ineos Fluor Ltd, which agreed a total reduction of $805,635 \mathrm{tCO}_{2} \mathrm{e}$ over the five years of the scheme, worth almost $£ 43$ million of incentive payments.

The operation of the scheme for DPs is as follows. At the start of each year, a cumulative target for emissions reductions equal to one-fifth of the total agreed target is imposed. Thus, for example, by the end of the first year, Ineos Fluor Ltd had to have reduced emissions from a baseline of 1,861,863 $\mathrm{tCO}_{2} \mathrm{e}$ by $161,127 \mathrm{tCO}_{2} \mathrm{e}$, by the end of the second year by $322,254 \mathrm{tCO}_{2} \mathrm{e}$ and so on. If the target is hit, the firm receives its incentive payment. If the target is not hit, the payment is withheld and the firm can be fined and see its allowances for the next period reduced.

The UK ETS is an example of a 'cap-and-trade' scheme in that the initial auction set a cap for each firm on the amount of emissions it could produce in each year, equal to the number of permits it received, which firms were then free to trade amongst themselves according to the costs each faced in meeting its cap.

The figures for the third year of the scheme (2004) revealed that all of the 32 active DPs had hit their targets. Indeed, 'overcompliance' was a feature of the scheme from the beginning: by the end of the first year, a total reduction relative to baseline levels of emissions of 0.79 million $\mathrm{tCO}_{2} \mathrm{e}$ was the target, whereas total abatement actually amounted to 3.85 million $\mathrm{tCO}_{2} \mathrm{e}$. This meant that many firms had effectively been able to 'bank' their abatement early and could therefore afford not to reduce emissions further and still hit their targets for the rest of the scheme's period. ${ }^{\mathrm{b}}$ Results for 2004 showed that the reduction of emissions relative to baseline was only 0.7 million $\mathrm{tCO}_{2} \mathrm{e}$, suggesting this might be the case.

More information about the UK ETS can be found at http://www.defra.gov.uk/environment/climatechange/trading/uk/index.htm, whilst the latest emissions data for the DPs for 2004 are available at http://www.defra.gov.uk/environment/climatechange/trading/uk/pdf/uketstargets.pdf.

\section{EU Emissions Trading Scheme}

The EU ETS began in 2005, described by the EU as 'the largest multi-country, multi-sector Greenhouse Gas emission trading scheme world-wide' c The first phase of the scheme will run until the end of 2007, with the second phase running from 2008 to 2012.

There are some differences between the UK and EU schemes. Both are 'capand-trade' systems where the overall level of emissions each participant is allowed to make is fixed and participants can then trade permits in order to hold sufficient to 
cover their emissions each year. However, the EU scheme covers only $\mathrm{CO}_{2}$ emissions whereas the UK scheme is based on a basket of greenhouse gases. In addition, the EU scheme is not voluntary for the industries covered. These are energy-intensive industries such as oil refineries, iron/steel plants and large factories. In the second phase of the scheme, the airline industry will also be covered. The penalty for firms that do not hold enough allowances to cover their $\mathrm{CO}_{2}$ emissions each year is $€ 40 /$ tonne.

Each EU Member State was required to submit a 'National Allocation Plan' (NAP) which set out the total amount of permits it would allocate and how they would be divided between the participants. ${ }^{\mathrm{d}}$ The total had to be in line with each country's Kyoto target. For the first phase, the UK allocated 736 million tonnes of $\mathrm{CO}_{2}$ permits (11 per cent of the EU total) to 1,078 installations across three years. Any new firms that enter industries covered by the EU ETS are allocated an allowance as well. Sixty-four firms that were 'direct participants' in the UK ETS are excluded from the EU ETS for 2006 and will join in 2007.

For the first year of the EU ETS, figures from the European Commission for 21 Member States showed total emissions of 1.785 billion tonnes of $\mathrm{CO}_{2}$ compared with allowances of 1.829 billion tonnes, ${ }^{\mathrm{e}}$ meaning that firms reduced emissions by around 2.4 per cent more than was required. This overcompliance mirrors the results of the UK ETS (though UK firms in the EU ETS emitted around 33 million tonnes of $\mathrm{CO}_{2}$ more than their permits allowed in total) and caused some criticism of the scheme as it implied that governments had been overgenerous in determining their NAPs. If firms appear more able to abate emissions than was first thought, however, it will of course be possible to renegotiate targets for the second phase.

\footnotetext{
a This feature amongst others led to some criticism of the scheme. For example, the Environmental Data Service (ENDS) argued that the voluntary nature meant only firms that expected to reduce emissions anyway would take part and that problems in determining firms' baseline emissions levels meant some firms could effectively meet their targets, and thus receive payments, for 'free' using existing emissions abatement plans.

${ }^{\mathrm{b}}$ Six of the firms with the largest targets in the scheme agreed voluntary additional reductions in 2004.

${ }^{c}$ See http://ec.europa.eu/environment/climat/emission.htm for the EU ETS homepage.

${ }^{\mathrm{d}}$ For the details of the UK plan, see http://www.defra.gov.uk/environment/climatechange/trading/eu/nap/pdf/0505nap.pdf. For a full list of actual permits allocated to each covered participant, see http://www.defra.gov.uk/environment/climatechange/trading/eu/nap/pdf/finalallocation.pdf.

See

http://europa.eu/rapid/pressReleasesAction.do?reference=IP/06/612\&format=HTML\&aged=0\&language=EN \&guiLanguage $=$ en
}

\subsection{Taxes on transport}

As noted in Chapter 3, fuel duties and vehicle excise duty together account for the vast majority of environmental tax revenues raised in the UK. It seems therefore logical to begin our measure-by-measure appraisal of the UK environmental tax system with taxes on transport. Further, as we saw in Figure 4.3 above, transport represented the only sector in the UK where $\mathrm{CO}_{2}$ emissions rose between 1990 and 2003, and it seems poised to become the single largest source of emissions in the UK. Evidence reported by the House of Commons Environmental Audit Committee (2006b) suggests that by 2020, transport will account for 31 per cent of total $\mathrm{CO}_{2}$ emissions, or 33 per cent including international aviation and shipping. 
Key to this has been a large increase in traffic volumes over the past decade. Figures from the Department for Transport (2006a) show that between 1990 and 2004, the total traffic (measured in vehicle kilometres) travelled by car and taxi rose by around 19 per cent, from 336 billion to 398 billion. Use of light vans increased by half, from 40 billion to 61 billion kilometres, and the use of HGVs by 18 per cent, from 25 billion to 29 billion kilometres. The number of private and light goods vehicles licensed rose from 22 million to 28.7 million. Between 1990-91 and 200405, use of public transport varied: the number of bus journeys in Britain fell from 4.8 billion to 4.6 billion (though the 2004-05 figure represented a rise on the low of 4.2 billion in 1998-99), whilst the number of train journeys rose from 809 million to 1.09 billion (and London Underground journeys from 775 million to 976 million). Behind these figures has been a large shift in the relative costs of private and public transport since 1990. Despite widespread belief that the cost of private motoring has risen, private transport costs rose no faster than other prices between 1990 and 2006 and rose less quickly than earnings (see Figure 5.1a). This is because large real increases in the price of fuel, tax, insurance and vehicle maintenance of up to 50 per cent were offset by a decline of almost 50 per cent in real terms in the costs of vehicle purchase. Rail and bus fares, by contrast, have risen by more than other prices and by more than average earnings since 1990 (see Figure 5.1b). Rail and bus fares are now both around 30 per cent more expensive in real terms than they were at the beginning of 1990 and the price of both has risen more quickly than real earnings.

\section{Figure 5.1}

Costs of transport relative to overall prices, January 1990 - April 2006 (January $1990=100)$

a) Private transport

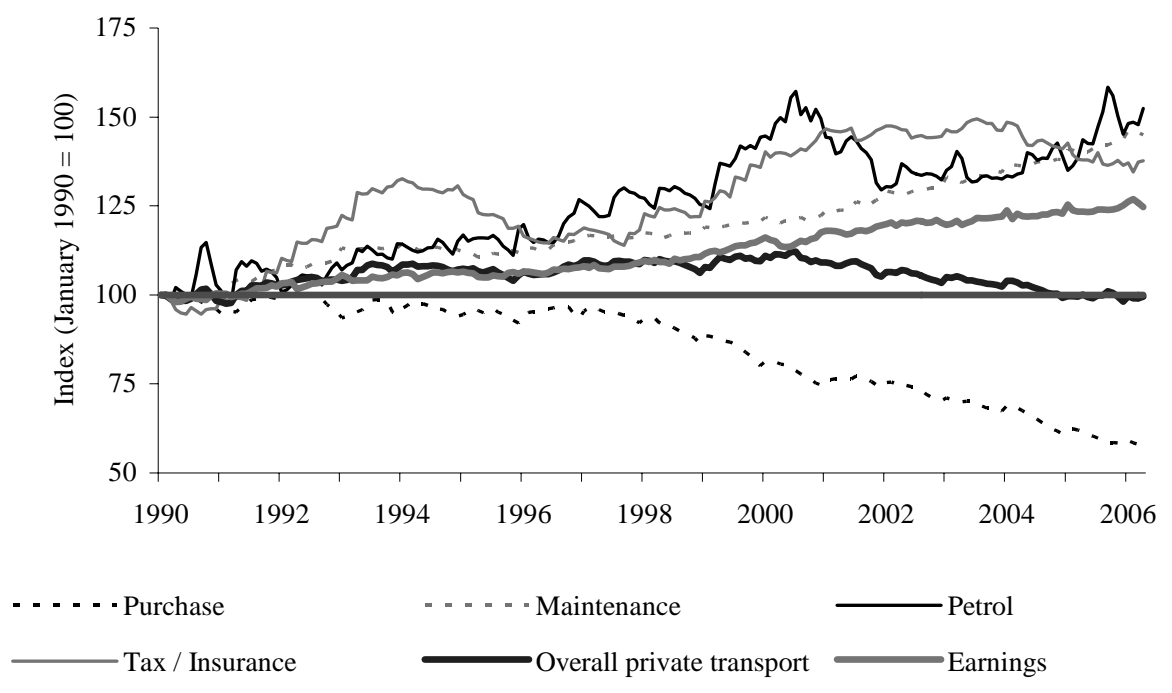


b) Public transport

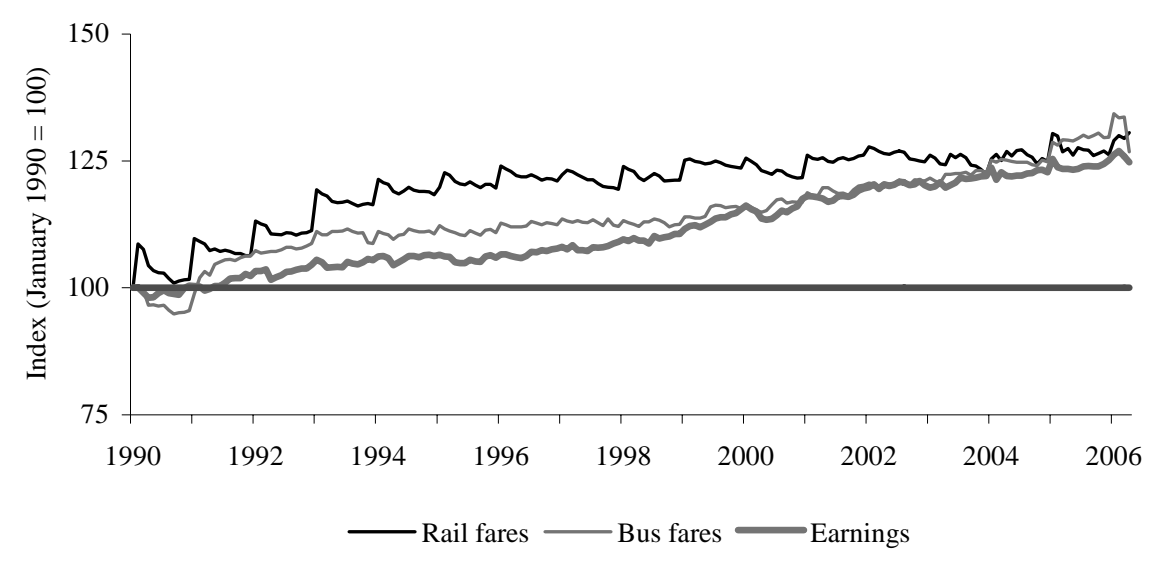

Notes: Values are the RPI index for each series (and the whole-economy average earnings index) deflated by the overall RPI index in each month. A figure above 100 indicates that the price was rising faster than other prices (i.e. it became relatively more expensive); a figure below 100 indicates that the price was rising more slowly (i.e. it became relatively cheaper).

Source: Author's calculations from ONS figures.

Taxes on transport, and car use in particular, are especially complicated because the externalities of motoring are many and varied. Aside from pollution externalities of $\mathrm{CO}_{2}$ and other emissions, there are external costs of noise, accidents, road building and maintenance, and congestion. Designing taxes to internalise all of these external costs accurately in the prices paid for motoring by consumers is very difficult, and sometimes the appropriate instruments will differ for different externalities. For example, $\mathrm{CO}_{2}$ emissions are roughly linear in fuel consumed such that a tax on fuel will capture this quite well. By contrast, congestion and accident externalities are dependent on location and time of driving, which taxes such as vehicle excise duty and fuel duty do not capture. Table 5.1 shows estimates of the range of marginal external costs (for 1998) of road travel for various different externalities based on work by Sansom et al. (2001). Their report found that whilst current road taxes more than cover the total external costs of motoring, they fail to capture the marginal costs. Nash et al. (2004) conclude from these figures that 'the current charging regime in Great Britain is, for the average motorist, only covering

Table 5.1

Estimated marginal external road costs (p/vehicle km), 1998

\begin{tabular}{l|rr}
\hline Externality & Low estimate & High estimate \\
\hline Operating costs & 0.42 & 0.54 \\
Accidents & 0.82 & 1.40 \\
Air pollution & 0.34 & 1.70 \\
Noise & 0.02 & 0.05 \\
Climate change & 0.15 & 0.62 \\
Congestion & 9.71 & 11.16 \\
\hline
\end{tabular}

Source: Sansom et al., 2001. 
at best $50 \%$ of their marginal social cost'. Their emphasis points out that the costs vary according to time, location and the type of motorist. Congestion costs dominate the total, though climate change and pollution costs are not insignificant. However, the variation by road type for congestion is very large - non-major rural roads are estimated to have a marginal external congestion cost of between 1.32 and $2.92 \mathrm{p} /$ vehicle $\mathrm{km}$ compared with a range of $85.76-85.87 \mathrm{p} /$ vehicle $\mathrm{km}$ for peak-time central London roads.

There has been some suggestion of moving towards a system of road pricing (and, indeed, in central London one has already been introduced) and attempting to value each of the externalities directly in the price charged for driving in a particular location at a particular time (see Section 6.1). If properly designed, this should, in principle, provide the optimal incentives for motorists, though there may be considerable logistical and technological barriers to such a system at present.

\subsubsection{Vehicle excise duty (VED)}

\section{Background and structure}

Vehicle excise duty is an annual tax levied on road vehicles. Some form of taxation of vehicles has been around since 1903, when the Motor Car Act taxed all road vehicles at a rate of 20 shillings. The Roads and Finance Act 1920 saw the introduction of the 'tax disc', with a tax rate of £1 per horsepower from 1921. From 1948 , road taxes were replaced with a flat-rate payment of $£ 10$ per year. It was not until 1999 that this flat-rate tax was replaced: from June 1999, 'small cars' with an engine size of less than 1,100cc paid a lower tax, of $£ 100$ per year, than larger cars, which at that time paid $£ 155 .^{14}$

For cars registered before 1 March 2001, this two-tier system remains in place: cars with an engine size below 1,550cc pay £110 per year whilst larger-capacity cars pay $£ 175$ per year. For cars registered on or after 1 March 2001, a system of VED 'bands' based on the emissions rating of the vehicle was introduced, which gave a much more explicit environmental tax feeling to the system of VED. This system of 'graduated' VED (GVED) has been further reformed and tweaked since then, most notably in Budget $2006^{15}$ when the rate of VED for cars with the lowest emissions rating ( $100 \mathrm{~g}$ or less of $\mathrm{CO}_{2}$ per kilometre driven, 'band A') was reduced to zero and a new higher rate for the highest-emissions vehicles $\left(226+\mathrm{g} \mathrm{CO}_{2}\right.$ per $\mathrm{km}$, 'band G') was introduced at £210 per year. These rates apply to petrol cars; slightly higher rates apply to diesel cars and lower rates to alternative-fuels cars, again giving a more environmental flavour to VED. Table 5.2 shows the rates of VED for petrol cars since 2000-01.

\footnotetext{
${ }^{14}$ Different rates apply for other road vehicles, such as motorbikes, buses and HGVs. For a full list for 200607 , see http://direct.gov.uk/Motoring/OwningAVehicle/HowToTaxYourVehicle/HowToTaxYourVehicleArticles/ss/en?C ONTENT ID $=4022118 \&$ chk=7JgfMw.

${ }^{15}$ See http://www.hm-treasury.gov.uk/media/20F/2F/bud06 cha 134.pdf.
} 
Table 5.2

Annual rates of VED / GVED for petrol cars

\begin{tabular}{|c|c|c|c|c|c|c|c|c|c|c|}
\hline & \multicolumn{3}{|c|}{ Registered before 1 March 2001} & \multicolumn{7}{|c|}{$\begin{array}{l}\text { Registered on or after } 1 \text { March } 2001 \\
\text { Emissions band }\left(\mathrm{g} \mathrm{CO}_{2} \text { per km): }\right.\end{array}$} \\
\hline & $\begin{array}{r}\text { Standard } \\
\text { rate }\end{array}$ & Small car & $\begin{array}{r}\text { Engine size } \\
\text { (small car) }\end{array}$ & $\begin{array}{r}A \\
(100 \\
\text { or less) }\end{array}$ & $\begin{array}{r}\text { B } \\
(101-120)\end{array}$ & $\begin{array}{r}C \\
(121-150)\end{array}$ & $\begin{array}{r}\mathrm{D} \\
(151-165)\end{array}$ & $\begin{array}{r}E \\
(166-185)\end{array}$ & $\begin{array}{r}F \\
(186-225)\end{array}$ & $\begin{array}{r}G^{a} \\
(226 \\
\text { or more })\end{array}$ \\
\hline $2000-01$ & $£ 155$ & $£ 100$ & $1,099 \mathrm{cc}$ & - & - & - & - & - & - & - \\
\hline $2001-02$ & $£ 160$ & $£ 105$ & $1,199 \mathrm{cc}$ & $£ 100$ & $£ 100$ & $£ 100$ & $£ 120$ & $£ 140$ & & E155 \\
\hline 2002-03 & $£ 160$ & $£ 105$ & $1,549 c c^{b}$ & $£ 70$ & $£ 70$ & $£ 100$ & $£ 120$ & $£ 140$ & & $£ 155$ \\
\hline 2003-04 & $£ 165$ & $£ 96$ & $1,549 \mathrm{cc}$ & $£ 65$ & $£ 75$ & $£ 105$ & $£ 125$ & $£ 145$ & & E160 \\
\hline 2004-05 & $£ 165$ & $£ 96$ & $1,549 \mathrm{cc}$ & $£ 65$ & $£ 75$ & $£ 105$ & $£ 125$ & $£ 145$ & & $E 160$ \\
\hline $2005-06$ & $£ 170$ & $£ 110$ & $1,549 \mathrm{cc}$ & $£ 65$ & $£ 75$ & $£ 105$ & $£ 125$ & $£ 150$ & & E165 \\
\hline $2006-07$ & $£ 175$ & $£ 110$ & $1,549 \mathrm{cc}$ & $£ 0$ & $£ 40$ & $£ 100$ & $£ 125$ & $£ 150$ & $£ 190$ & $£ 210$ \\
\hline
\end{tabular}

${ }^{a}$ Band G of GVED applies to cars registered on or after 23 March 2006; cars registered before then pay the band $F$ rate.

b Increased engine size threshold to 1,549cc applies from June 2001.

Source: Various Budget documents. 


\section{Revenue}

The Treasury estimates that VED raised around $£ 5$ billion in 2005-06, or 1.0 per cent of total revenues that year. For 2006-07, the forecast is revenue from VED of $£ 5.1$ billion, or 1.0 per cent of total forecast revenue that year. ${ }^{16}$

Figure 5.2 shows historical revenues from VED, back to 1964, in 2004 prices. Receipts have tended to rise over time, both as the rate of VED has increased and as the number of vehicles on the road has risen. It is worth noting that the reforms in 1999, which saw two rates introduced for cars with different engine sizes, led to a net reduction in revenues - in real terms, revenue was around $£ 1$ billion less in 2001 than in 1999. Since then, revenues have risen steadily despite quite substantial reforms to the system as described above, though these were designed to be revenue-neutral.

The Department for Transport estimates that around $£ 147$ million was lost to evasion of VED in 2005-06, representing 3.6 per cent of total revenue from VED. ${ }^{17}$

Figure 5.2

Receipts from VED ( $£$ billion, 2004 prices)

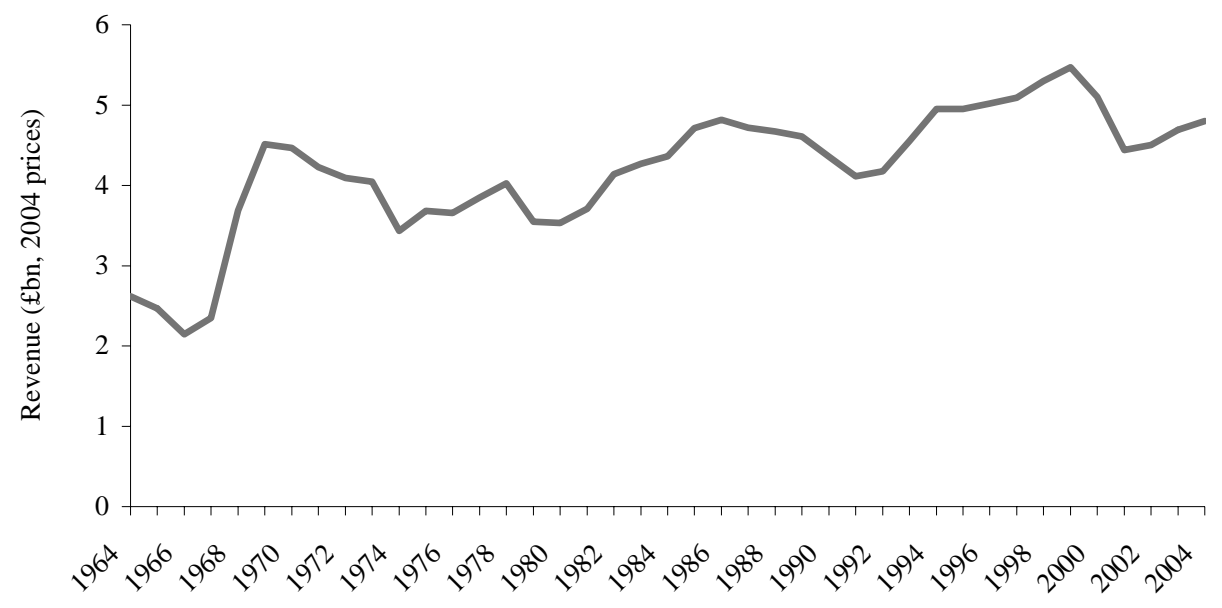

Sources: Blue Book, various years; GDP deflator from HM Treasury.

\section{Distributional effects}

Assessing the distributional effects of the current system of VED is extremely difficult because of the relatively complex nature of the tax as it now stands, based on emissions ratings. When VED was a simple flat-rate tax, it was relatively straightforward to model the distributional effects, since all that was required was data on car ownership rates at different points along the income distribution. Work by Blow and Crawford (1997), for example, demonstrated that an increase in VED of around 30 per cent would increase the cost of living of the poorest tenth of

\footnotetext{
${ }^{16}$ HM Treasury forecasts from Budget 2006.

17 See http://www.dft.gov.uk/stellent/groups/dft transstats/documents/page/dft transstats 610095.hcsp.
} 
households by around 0.4 per cent, the middle tenth of households by around 0.8 per cent and the richest tenth of households by 0.6 per cent. These figures reflect the fact that poorer households tend not to own cars at all and so are unaffected by changes in VED rates. If attention is restricted to car-owning households, then VED is strongly regressive, as we would expect from a flat-rate tax ${ }^{18}$ - the poorest tenth of car owners lose by around 1.8 per cent whilst the richest tenth lose by around 0.6 per cent.

Now that the system of VED is more complicated, much more detailed data are needed to estimate the distributional effects accurately. We need to know not just whether and how many cars are owned across the income distribution, but also when the car was registered, the engine size and the emissions rating. To the extent that car age, engine size and rating do not vary across the income distribution, then we would still expect a similar story to that under the old system to emerge: the effect of VED is 'hump-shaped' across the whole income distribution, with middleincome households paying relatively more of their income and rich and poor households relatively less, whilst it is strongly regressive across the car-owning income distribution. However, these effects may be mitigated if, say, richer households tend to own larger and less fuel-efficient cars. Alternatively, if poorer households tend to own older cars registered before the GVED system was implemented, and richer households tend to own newer, more efficient cars, then the regressivity of GVED may be even stronger than the regressivity of VED.

\section{VED as a green tax}

Clearly, VED has taken on a much greener hue since the reforms of 2001. The tax rate is now explicitly linked to the emissions rating of the vehicle. Reforms since 2001 have only tended to accentuate this: the gap between highest and lowest rates of VED has widened from $£ 55$ in 2001-02 to £210 in 2006-07.

What economic rationale exists for VED? It represents a fixed cost of car ownership. As such, it does not provide motorists with any incentive to drive less; the same amount is payable if the car is driven 1 mile in a year as if it is driven 100,000 miles. However, it does provide an incentive to choose more fuel-efficient cars, which attract a lower tax rate, or, at the margin for some motorists, to choose not to own a car at all. It also provides a much clearer price signal than fuel duty for consumers to purchase less polluting models since the tax is linked explicitly to emissions. By contrast, fuel duty encourages more efficient cars that can be driven further for each litre of petrol; these will also tend to be less polluting but the link is not so direct. A further reason for VED may be that it encourages motorists to scrap old, more polluting cars, which are presumably less valuable as they age, and replace them with new, less polluting cars where the VED represents a smaller fraction of the total value.

Data from the Society of Motor Manufacturers and Traders Ltd (2006) show that the average emissions rating of new cars purchased has been steadily declining, and that this began even before the reform to VED in 2001. Figure 5.3 shows the trend since 1997. If anything, the rate of decline has slowed since 2001. The average emissions of new cars purchased depend on the technology of the manufacturers

\footnotetext{
18 Though, of course, even flat-rate VED could be progressive to the extent that richer households tend to own more than one car, and the duty is payable per car and not per household or per owner.
} 
Figure 5.3

Average new car emissions

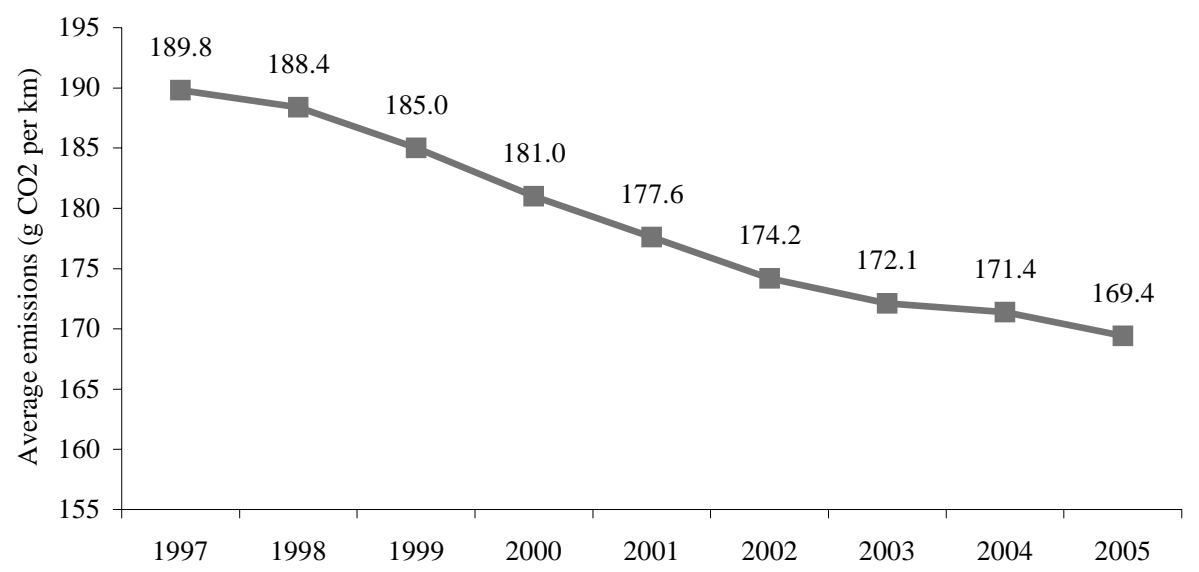

Source: Society of Motor Manufacturers and Traders Ltd, 2006.

and the demands of the consumers. Since 1997, there has been a big shift towards diesel-engine vehicles, which have lower emissions, and away from high-emission petrol-engine vehicles. Only 17 per cent of new car purchases were diesel in 1997, compared with 37 per cent in 2005. Average emissions for diesel cars in 2005 were $165 \mathrm{~g} \mathrm{CO}_{2}$ per km compared with 172 for petrol cars, though the average for both types has declined, from 187g CO $\mathrm{CO}_{2}$ per km for diesel cars in 1997 and 190 for petrol cars.

A more direct assessment of the impact of VED reforms on car choice can be made by looking at the distribution of purchases by VED band. Table 5.3 shows the percentage of new vehicles purchased in each VED band (A-F) from 1997 to 2005. Certainly, there appears to be evidence of changing consumer preferences over time, but it is worth noting that the trend away from high-band purchases was

Table 5.3

Percentage of new car purchases by 2005 VED band

\begin{tabular}{l|rrrrrr}
\hline & Band A & Band B & Band C & Band D & Band E & Band F \\
\hline 1997 & 0.0 & 0.0 & 7.8 & 15.1 & 32.0 & 45.1 \\
1998 & 0.0 & 0.0 & 8.9 & 18.0 & 31.2 & 41.9 \\
1999 & 0.0 & 0.0 & 11.8 & 25.0 & 25.8 & 37.4 \\
2000 & 0.0 & 0.1 & 19.2 & 23.8 & 22.7 & 34.3 \\
2001 & 0.0 & 0.6 & 23.1 & 23.8 & 20.6 & 31.8 \\
2002 & 0.0 & 2.0 & 25.8 & 24.3 & 19.0 & 28.8 \\
2003 & 0.0 & 3.0 & 31.2 & 21.2 & 17.8 & 26.8 \\
2004 & 0.0 & 3.1 & 30.1 & 23.6 & 17.2 & 25.9 \\
2005 & 0.0 & 3.3 & 30.8 & 24.9 & 17.2 & 23.8 \\
\hline
\end{tabular}

Source: Society of Motor Manufacturers and Traders Ltd, 2006. 
underway before the reforms in 2001. It is therefore very hard to disentangle the contribution made by reforms to VED and changes to manufacturing processes or a preference for smaller cars in the face of, say, increased congestion.

It is unclear whether reforms to VED, as opposed to changes in manufacturing standards or changing preferences for other reasons, have really affected consumer behaviour and preferences. The difference between a band $\mathrm{C}$ rate and a band $\mathrm{G}$ rate in 2006-07 is just $£ 110$ per year, a relatively small part of the overall running costs of a vehicle. In response to the 2006 Budget, Greenpeace called for the band G rate to rise to $£ 1,800$ per year. ${ }^{19}$

\section{The future of VED}

The system of VED is unlikely to be scrapped altogether, as a £5 billion contribution to receipts each year is fairly substantial. Nor is it likely to be scrapped and replaced with higher fuel duties; even though VED has now taken on a greener structure, there are good economic reasons to keep a fixed charge (as discussed above) as well as having taxes that vary with distance driven. There has been some suggestion that a future system of road pricing (see Section 6.1) could see VED replaced or reduced, though that is likely to be many years ahead.

The most likely reforms to VED in the future are to make a greater distinction between high- and low-polluting vehicles. As Table 5.2 demonstrated, the rate of VED for low-emissions vehicles has tended to fall rather than rise and increases in VED have been concentrated on vehicles that have higher emissions. This trend is likely to continue in the immediate years ahead.

\subsubsection{Fuel duty}

\section{Background and structure}

Duties on road fuels represent the single largest green tax in the UK, and certainly the most controversial, as the protests of 2000 made clear.

Whereas VED represents a fixed cost of motoring, fuel duty represents a marginal cost, with more payable by those who drive further. Taxes on fuel were introduced in 1909 at 3d per gallon; the tax was abolished in 1919 and reintroduced at 4d per gallon in 1928.

The key development in fuel duties came in the 1993 Budget, when then Chancellor Norman Lamont announced the introduction of the fuel price 'escalator'. The escalator meant that in each Budget, fuel duty would be increased by at least 3 per cent above the rate of inflation. At the time, this was introduced explicitly as an environmental move:

The duty on road fuels will be raised on average by at least 3 per cent in real terms in future Budgets. This will encourage more efficient use of fuel and reduce emissions of carbon dioxide.

HM Treasury, 1993

In November 1995, Chancellor Kenneth Clarke announced that the escalator would rise from 3 per cent above inflation to 5 per cent, and in his first Budget, in

\footnotetext{
${ }^{19}$ See

http://www.greenpeace.org.uk/climate/climate.cfm?ucidparam=20060322134057\&CFID=4458013\&CFTOKE $\mathrm{N}=33689483$.
} 
July 1997, Gordon Brown increased the rate to 6 per cent. This lasted until the November 1999 Pre-Budget Report, when the escalator was abandoned, interestingly before the fuel protests of 2000. Abandonment of the escalator came despite the documentation of the PBR noting that

[The escalator] has given a clear signal to motorists and manufacturers to design more fuel efficient vehicles, avoid unnecessary journeys and consider alternatives to the car. Increases in fuel duties since 1996 are estimated to produce carbon savings of between 1 and 2.5 million tonnes of carbon by 2010 .

HM Treasury, 1999

Since then, the rates of fuel duty on the two most common fuels - ultra low sulphur petrol (ULSP) and ultra low sulphur diesel (ULSD) - have risen in nominal terms only once, despite repeated assertions in Budget and Pre-Budget documents that policy is to raise duty in line with inflation. The government tends to argue that high and volatile oil prices mean duties should not rise even in cash terms. From an economic theory perspective, it is hard to argue this case - depending on the structure of private and social costs, it is possible to find examples where increases in the pre-tax price of fuel would call for higher, lower or unchanged rates of duty (see pages 11-12 of Leicester (2005), for example).

The majority of road fuel used by private motorists is taxed at $47.1 \mathrm{p}$ per litre in 2006-07, though different rates apply for alternative fuels, airline fuel and fuel used in vehicles that are primarily off-road vehicles such as agricultural vehicles and motor boats. This latter fuel is often referred to as 'red diesel' as it is chemically marked and dyed red to show that a reduced rate of duty applies. A full list of rates is available at the HMRC website. ${ }^{20}$ The key figures as at April 2006 are given in Table 5.4.

Table 5.4

Key fuel duty rates, April 2006 (pence/litre)

\begin{tabular}{l|r}
\hline Light oils & \\
Ultra low sulphur petrol (ULSP) / Sulphur-free petrol (SFP) & 47.10 \\
Other unleaded petrol & 50.19 \\
Aviation gasoline & 28.10 \\
Heavy oils & \\
Ultra low sulphur diesel (ULSD) / Sulphur-free diesel (SFD) & 47.10 \\
Conventional diesel & 53.27 \\
Red diesel & 6.44 \\
Biofuels & \\
Biodiesel / Bioethanol & 27.10 \\
Road fuel gases & \\
Natural gas / Liquefied petroleum gas (LPG) & $9.00^{\mathrm{a}}$ \\
\hline a In pence/kilogram. & \\
Source: HM Revenue and Customs (HMRC). &
\end{tabular}

${ }^{20}$ http://customs.hmrc.gov.uk/channelsPortalWebApp/downloadFile?contentID=HMCE PROD1 024961. 
Figure 5.4

Nominal duty rates for key fuels
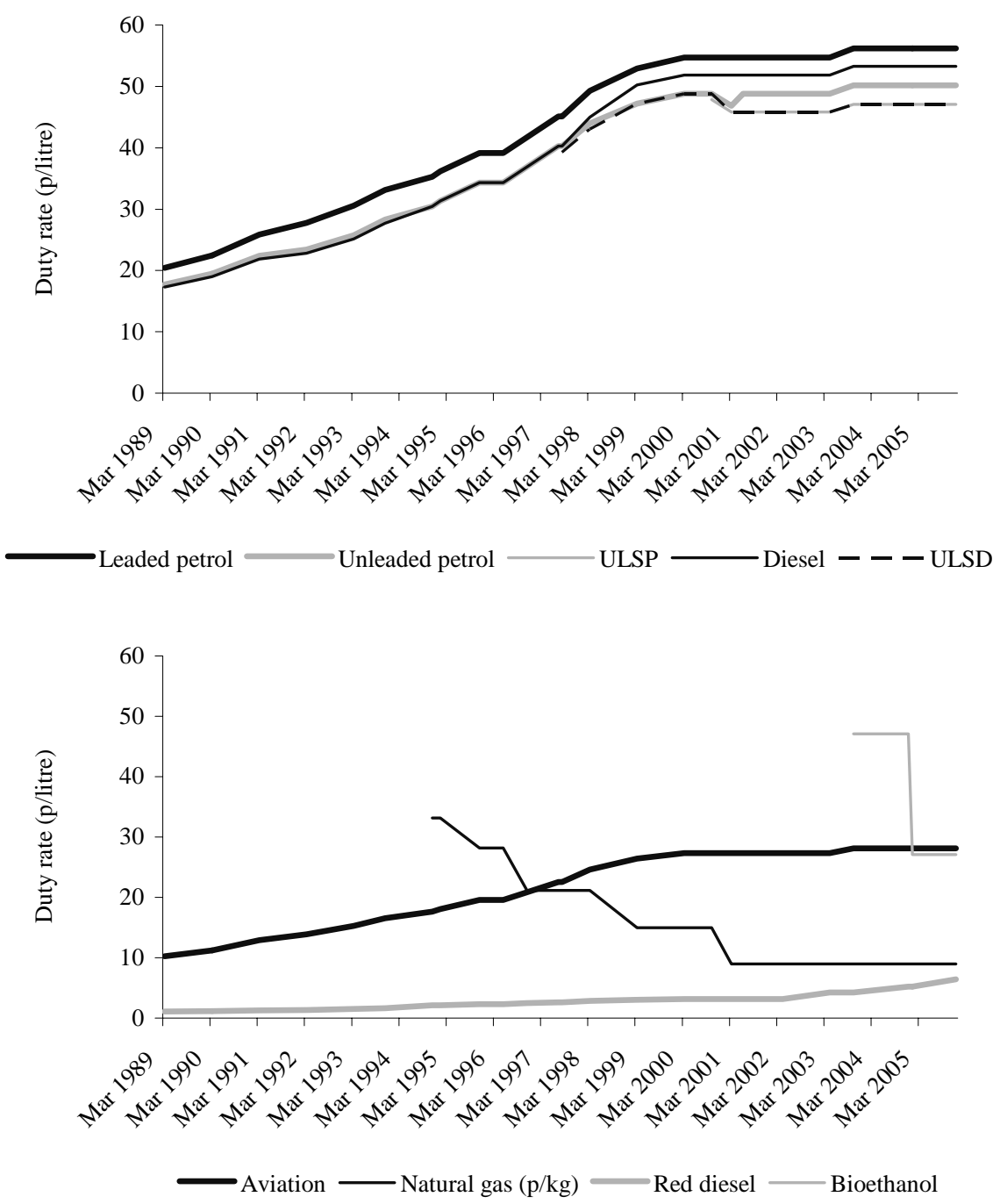

Source: HM Revenue and Customs, 2006e.

Figure 5.4 shows nominal rates of duty between 1989 and 2006. It is clear that the structure of fuel duties has been changing quite rapidly owing to changes in the types of fuel available. Typically, however, more polluting fuels have been taxed at a higher rate than less polluting fuels (consider, for example, leaded versus unleaded petrol), which would be consistent with a higher external cost. The impact of the escalator is clear in the rates for leaded and unleaded petrol and diesel, though it is worth noting that rates were rising even before 1993. The environmental incentives 
within fuel duties have been increased by cuts in duty for natural gas and bioethanol in recent years.

Clearly, there are incentives in the fuel duty system for motorists both to choose more fuel-efficient vehicles (such that a given quantity of fuel affords further distance travelled) and to choose the least polluting fuels such as biofuel or LPG. At present, however, very few vehicles use alternative fuels. There is also considerable controversy over whether aviation fuels and 'red diesel' should be taxed at lower rates. One argument for lower taxes on aviation fuel, for example, is that airlines could choose to refuel abroad where taxes were lower such that it would require an international commitment to higher fuel taxes for them to be effective. However, the remainder of this section will focus on the taxation of on-road vehicles using ULSP and ULSD. ULSP accounts for virtually 100 per cent of motor spirits sold in the UK, and ULSD/SFD almost 100 per cent of diesel (other, more polluting petrol and diesel taxed at a higher rate are virtually no longer sold - see table 2 of HM Revenue and Customs (2006e)). For 2005-06, an estimated 6.6 billion litres of red diesel were sold, compared with 23.5 billion litres of traditional diesel and 25.5 billion litres of motor spirit (petrol). By contrast, bioethanol and LPG accounted for around 330 million litres of fuel, or 0.6 per cent of total sales. Technological changes and tax incentives may see this share rise in future years, but at present the key taxes to focus on are those on ULSP and ULSD.

Figure 5.5

Real duty rates on ULSP / ULSD (and predecessors)

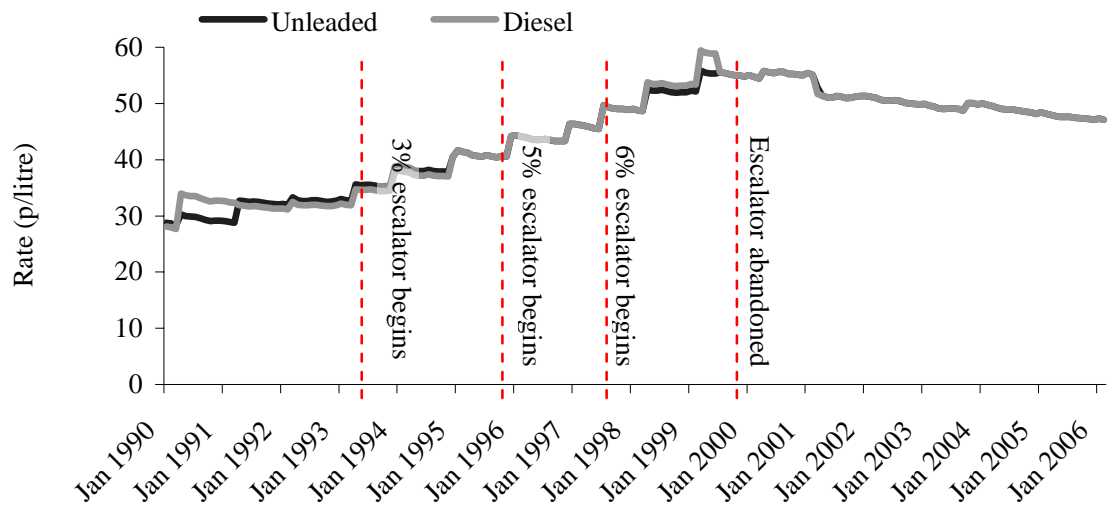

Source: Calculated from DTI data.

Figure 5.5 shows the real (inflation-adjusted) value of duty on ULSP and ULSD between January 1990 and February 2006. ${ }^{21}$ The impact of the fuel duty escalator is clear; between 1993 and 2000, real duty rates rose from around 32p/litre to between 55 and 60p/litre, almost doubling. Since the abandonment of the escalator, duty rates have fallen in real terms as they have been frozen in nominal terms. By

\footnotetext{
${ }^{21}$ Data are for duty on unleaded petrol up to March 2001 and ULSP thereafter and for duty on diesel up to June 1999 and ULSD after that. These changes account for the drop in duties at these points. Figures are adjusted by the all-items retail price index (RPI).
} 
February 2006, real fuel duty rates were at their lowest since June 1997, when the current government came to power. This real decline in fuel duties amounts to around 15.7 per cent from the peak value in March 1999 for unleaded petrol and 20.7 per cent from the peak value for diesel in the same month. The most recent Treasury estimates suggest that a 1 per cent rise in petrol duties raises around $£ 120$ million a year and a 1 per cent rise in diesel duties around $£ 110$ million, assuming no change in behaviour as a result. ${ }^{22}$ Using these estimates suggests that, had the government maintained fuel duty rates at their peak values in real terms, revenues from fuel duty would now be up to $£ 4.2$ billion a year higher. ${ }^{23}$ Estimating the environmental impact is much more difficult. Campaign groups have routinely expressed disappointment that fuel duties have remained frozen in cash terms after each recent Budget, ${ }^{24}$ but direct evidence on the link between duty rates and emissions and estimates of the emissions impact of the abandonment is hard to come by. The government estimates that cuts to duties in the 2001 Budget would increase emissions by between 0.1 and $0.2 \mathrm{MtC}$ by $2010 .^{25}$

\section{Revenue}

Fuel duty is the single largest source of green tax revenue for the exchequer. Excluding VAT levied on fuel, ${ }^{26}$ the government estimates that duties on hydrocarbon oils will raise £23.5 billion in 2005-06 and £24 billion in 2006-07, representing 4.8 per cent and 4.6 per cent of total revenues respectively. ${ }^{27}$ At an individual measure level, only income tax, National Insurance, VAT and corporate taxes raise more revenue than fuel duties.

Figure 5.6 shows historical revenues from fuel duties between 1964 and 2004 in 2004 prices. Real revenues remained at around $£ 10$ billion during the 1960s and 1970s. Through the 1980s, they rose relatively slowly, reaching $£ 15$ billion by 1988 before falling back slightly. From 1991, real revenues grew quickly, peaking at over $£ 25$ billion in 2000 when the escalator was ended. Since then, real revenues have declined somewhat, largely as a result of the real-terms cuts in duty observed in Figure 5.4.

Fuel duty revenues depend on the total volume of traffic, traffic speed and efficiency, and the type of fuel used as well as on the rate for each fuel type. Higher fuel duties in the 1990s appear to have encouraged people to switch away from polluting leaded petrol towards less polluting diesel and unleaded petrol (before both were superseded by ULSD and ULSP). Figure 5.7 shows the share of total fuel duty revenues contributed by sales of petrol, diesel, rebated fuel (such as red diesel) and gas/bioethanol since 1996. It is evident that revenue from diesel has almost overtaken revenue from petrol - in 1996 petrol sales contributed 64 per cent of

\footnotetext{
22 HM Treasury, 2005.

${ }^{23}$ Note that the 'cost' of abandoning the escalator is even greater since presumably this would have seen the real duty rise beyond the March 1999 peak whereas the figure quoted is the revenue cost of simply failing to maintain real duty rates since then.

${ }^{24}$ See, for example, Friends of the Earth at http://www.foe.co.uk/resource/press releases/budget 2006 brown starts t 22032006.html.

${ }^{25}$ http://www.hm-treasury.gov.uk/Documents/Taxation Work and Welfare/Tax and the Environment/

$\frac{\operatorname{tax} \text { environ budgets.cfm. }}{{ }^{26} \text { We will not consider VAT on petrol as an explicit environmental tax in this report since it is levied at the }}$ same rate as VAT on most other goods. This means the VAT system does not provide explicit environmental incentives in this case.

${ }^{27}$ HM Treasury, 2006b.
} 
revenues whilst diesel sales contributed 35 per cent, but by 2005 these figures were 52 per cent and 47 per cent respectively. Rebated fuels typically account for between 1 and 2 per cent of revenues. Gas-powered fuel and bioethanol contributed only 0.14 per cent of revenues in 2005.

Figure 5.6

Fuel duty revenues

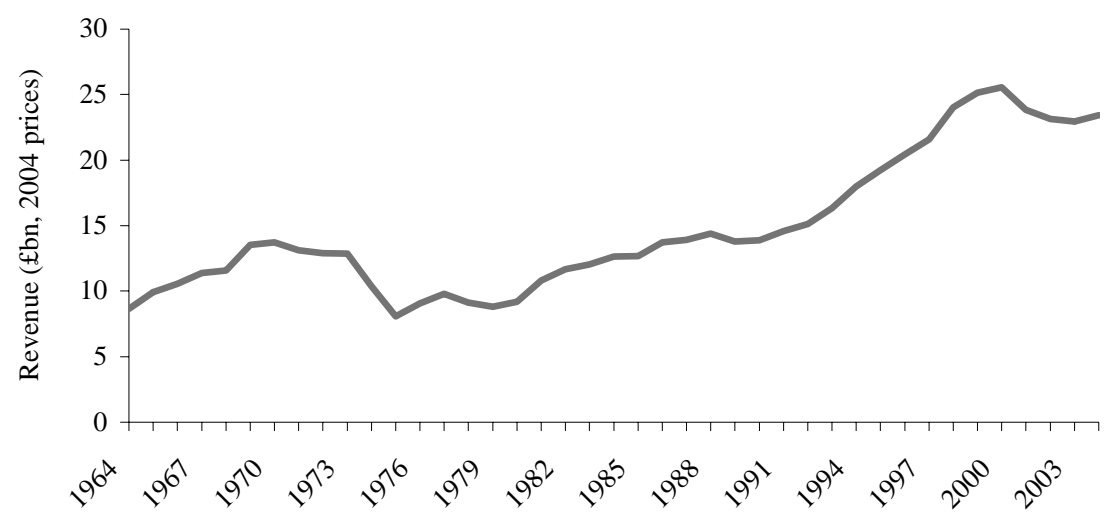

Source: Office for National Statistics, National Accounts ('Blue Book'), various years.

Figure 5.7

Share of total revenues by fuel type

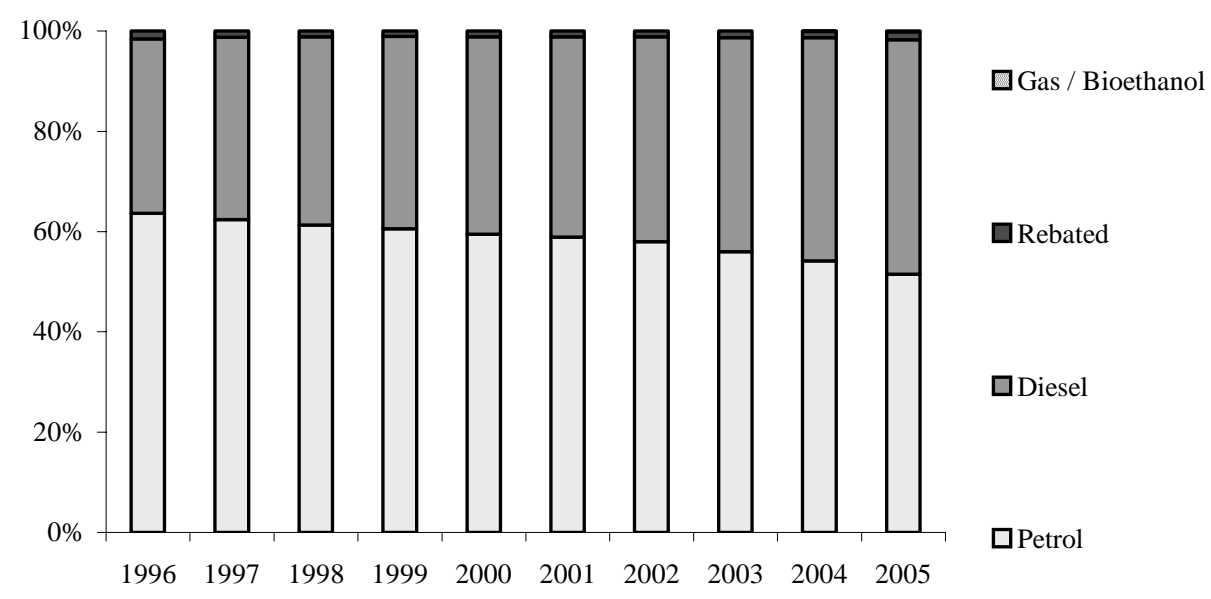

Source: HM Revenue and Customs, 2006e. 


\section{Distributional implications}

As the largest of the environmental taxes considered here, distributional concerns around fuel duties are more important than around any other single tax. An increase in fuel duty would be expected to hit the poor more than the rich since the tax rate is the same across the income distribution. However, two factors may mitigate against this: first, poor people will be less likely to own a car, which would mean they are unaffected by higher fuel taxes (unless they are passed on in, say, public transport fares as well); and second, rich people may choose less fuel-efficient cars, own more cars or drive more, all of which would see them harder hit by fuel tax rises.

Figure 5.8 shows the increase in the cost of living across the income distribution resulting from a 5 per cent increase in the price of fuel (whether this comes through taxation increases or oil price increases). We use data from the 2003-04 Expenditure and Food Survey and compare them with data from the 1990 Family Expenditure Survey to provide some historical perspective. In each year, we split the sample of households into 10 equally sized groups based on their income, poorest on the left and richest on the right of each graph. The bars show the average rise in the cost of living (defined as the increase in fuel spending after the 5 per cent price rise divided by the pre-rise total spending) within each of these income groups. The top panel shows all households, the bottom panel just those households that own at least one car. This will help demonstrate how much of our result is due to differential car-ownership rates across the income distribution.

Figure 5.8

Distributional impact of a 5 per cent fuel price rise

a) All households

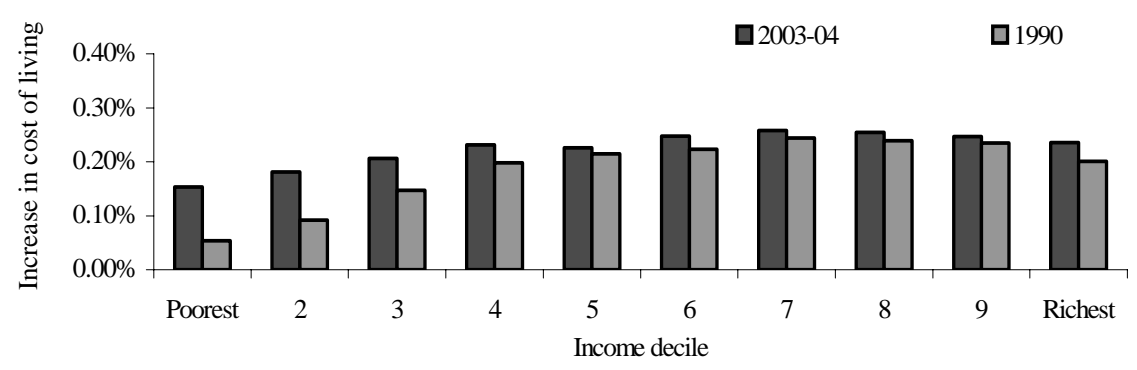

b) Car-owning households only

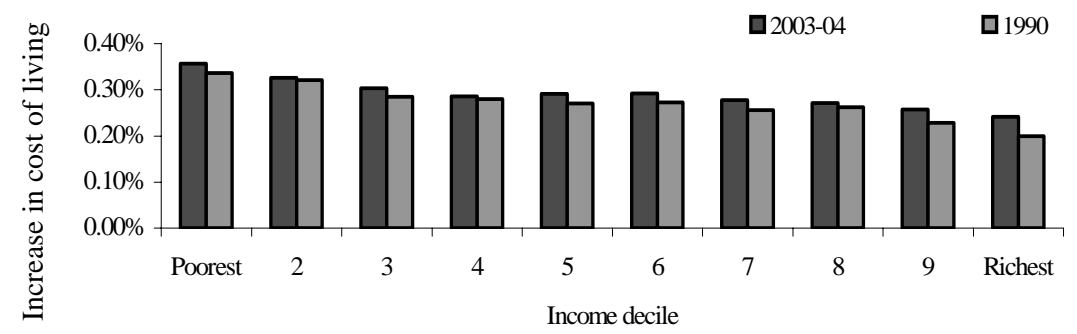

Note: Income and expenditure were equivalised using the OECD equivalence scale.

Source: Author's calculations from Expenditure and Food Survey 2003-04 and Family Expenditure Survey 1990. 
Across all households, a 5 per cent fuel price rise is not clearly regressive. The largest impact appears to be towards the top of the income distribution - households in the $7^{\text {th }}$ and $8^{\text {th }}$ income deciles typically face a cost of living increase of around 0.25 per cent whereas those in the poorest decile face an increase of around 0.15 per cent on average. However, since 1990, the impact of a fuel price rise has increased most strongly for those at the bottom. Clearly, car ownership plays a large role in this result since the lower panel demonstrates that amongst car-owning households only, a fuel price rise impacts most strongly on those at the bottom of the income distribution. The poorest tenth of car owners see their cost of living rise by around 0.36 per cent whilst the richest tenth see theirs rise by around 0.24 per cent. Looking at the raw figures for car ownership, it is not hard to see why the picture reverses between the two results: only 41 per cent of households in the poorest income decile in 2003-04 owned a car, compared with 96 per cent of households in the richest income decile.

How important are these distributional effects? Over a long period of sustained fuel price rises such as those brought about through the escalator and, more recently, through high crude oil prices, the distributional effects may accumulate to be of some concern, especially if the rich are more easily able to substitute towards more fuel-efficient vehicles or alternative fuels. Although the overall distributional effects are not clear from Figure 5.8, it is likely that the people at the bottom of the income distribution who do drive will be hit particularly hard, and this will mitigate the effects of current anti-poverty policies (there is no such thing as 'petrol benefit', for example!). It is also worth noting that the effects will be felt differently not just amongst rich and poor but also by, say, location of residence - rural dwellers with little alternative to driving their own car may tend to be hit harder by fuel price rises than urban dwellers who can substitute to public transport.

One point to bear in mind, however, is that increases in the price of fuel will feed into the price index used to uprate state benefits such that the incomes of the poorest households will tend to rise slightly as a result. Of course, this will benefit poor non-car-owning households in receipt of benefits and may not compensate all low-income households fully, but it is a general point that higher prices resulting from environmental taxes that may have adverse distributional effects could be mitigated somewhat by the feedback into the statutory uprating of the benefits system.

\section{Fuel duty as a green tax}

Fuel duty increases the marginal cost of each journey made. As such, it should reduce the total number of trips - in principle, those for which the benefit of driving only just exceeds the cost of driving as opposed to some alternative method of transport (or not making the journey at all). For people who make only these marginal journeys, higher fuel taxes might encourage them to give up their car altogether. Further, as suggested earlier, a longer-run effect will be to encourage purchase of more fuel-efficient vehicles, an effect accentuated by the tax system discriminating between regular and alternative fuels.

The extent to which people reduce their mileage as a result of higher fuel prices (whether these come about through taxation or higher pre-tax prices - it is not clear why people would respond differently to price increases through different channels) depends on the own-price elasticity of demand for petrol. This will be affected by 
the availability and price of substitutes such as public transport and alternative fuels. A recent survey of the literature carried out by the Centre for Transport Studies at University College London (Hanly, Dargay and Goodwin, 2002) suggests that a 10 per cent rise in the price of fuel reduces fuel consumption by around 2.5 per cent and the volume of traffic by 1 per cent after a year. The traffic volume falls less than the fuel consumption because of the incentives to switch to more fuel-efficient vehicles. The authors estimate long-run effects of a 6 per cent fall in fuel consumption and a 3 per cent fall in traffic volume, and that the effects on vehicle ownership are small and uncertain. These estimates imply that had the real rates of duty been maintained at their peak values since 1999, we might expect current fuel consumption to be around 4-5 per cent lower (and as much as 9-12 per cent lower in the long run).

These estimates assume all else remains unchanged, which, of course, is unlikely. In particular, incomes rise over time, and higher incomes mean that fuel and motoring more generally become more affordable. Indeed, whilst real duties have remained constant or fallen in recent years, relative to incomes petrol taxes have been declining. In addition, fuel represents just one part of the overall cost of driving - costs of vehicle purchase and servicing, for example, are other crucial factors. In recent years, the overall cost of motoring has declined. Of course, in the absence of higher fuel prices, the decline would have been greater, but it is important to bear in mind that fuel costs are not the full story when looking at the decision of a household on whether to own a car and, if so, how much to use it. This was demonstrated in Figure 5.1a. In addition, figure 3 of House of Commons Environmental Audit Committee (2006a) takes a longer historical perspective and shows that between 1980 and 2004, the real cost of motoring declined by around 15 per cent whilst household disposable incomes grew by around 95 per cent.

The aim of fuel duty as a green tax should be to send the correct price signal to motorists such that the distance driven is brought down to the socially optimal level, taking into account the external costs of motoring. To the extent that these costs are associated with fuel consumption, such as greenhouse gas emissions, fuel duty should work well as an environmental tax. The costs of emissions depend on distance driven and are not related to the time of day or location. Other external costs, such as accidents, noise, local pollution, congestion and road damage, will not be well targeted through fuel duty since they will depend on where and when the journey is undertaken and these factors are not reflected in the price signal from fuel duties that are invariant to time of day or location.

\section{Fuel taxes in the future}

Fuel tax rises, at least above inflation, seem to be unlikely in the immediate future. Tax rates for ULSP and ULSD have risen only once since 1999. In the event that oil prices decline substantially, duty rates may begin to rise once more, but it will be politically difficult to renew large, year-on-year real-terms increases such as those seen under the escalator. Reforms to fuel duties are most likely to centre on incentives for alternative fuels and perhaps increases in the rates of duty on aircraft fuel and red diesel.

In the longer term, reform to fuel duty may come as part of a wider package of reforms to transport taxes, centred on road pricing (see Section 6.1). 


\subsubsection{Air passenger duty}

\section{Background and structure}

Air passenger duty (APD) was introduced in the November 1993 Budget by Kenneth Clarke, who argued that air travel was undertaxed compared with other sectors thanks to zero-rating for VAT and low- or no-tax fuel. It was first charged in November 1994. There is some controversy over whether APD is an environmental tax at all - when introduced, it was not done as an explicitly environmental measure, and the Treasury tends not to refer to it as such. John Healey, Financial Secretary to the Treasury, has argued that

[APD] has never been an environmental tax.... it does, however, contribute to the recognition that ... the aviation industry has to pay the costs, the externalities if you like, that it imposes on society and on the environment.

House of Commons Environmental Audit Committee, 2006a

If APD is indeed designed such that the aviation industry pays external costs imposed on society, then it would appear to be an environmental tax in all but name, and indeed the ONS categorises it as such (it is included in all the environmental tax revenue data presented in Chapter 3, for example). The aviation sector has contributed a growing amount of emissions in the UK - estimates from the Department for Environment, Food and Rural Affairs (DEFRA) are derived from refuelling at UK fuel bunkers by UK- and non-UK-based airlines and show that between 1990 and 2004, total emissions from aviation rose from 4.3 MtC to 9.1 MtC, more than doubling. ${ }^{28}$

APD is a tax levied on airlines based on the number of eligible passengers flying domestically or internationally from UK airports (other than flights from the Scottish Highlands or Islands). Small aircraft of less than 10 tonnes or with fewer than 20 passenger seats are exempt. Children aged under 2 who do not have their own seat are exempt, as are trips on connecting flights. Short pleasure flights of less than 60 minutes do not attract APD. ${ }^{29}$

When introduced, APD varied according to whether the flight was within or outside the EU / European Economic Area (EEA). Domestic and EU/EEA destinations were charged at $£ 5$ whilst non-EU/EEA destinations were charged at

Table 5.5

Rates of APD, 1994-2006

\begin{tabular}{|c|c|c|c|c|}
\hline & \multicolumn{2}{|c|}{ EU rate } & \multicolumn{2}{|c|}{ Non-EU rate } \\
\hline 1 November 1994 & \multicolumn{2}{|c|}{$£ 5$} & \multicolumn{2}{|c|}{$£ 10$} \\
\hline \multirow[t]{2}{*}{1 November 1997} & \multicolumn{2}{|c|}{$£ 10$} & \multicolumn{2}{|c|}{$£ 20$} \\
\hline & Economy class & Higher classes & Economy class & Higher classes \\
\hline 1 April 2001 & $£ 5$ & $£ 10$ & $£ 20$ & $£ 40$ \\
\hline
\end{tabular}

Note: EU rate payable for flight destinations in the UK, EU and EEA.

\footnotetext{
${ }^{28}$ See http://www.defra.gov.uk/environment/statistics/globatmos/download/xls/gafg20int.xls.

29 Full details of the structure and exemptions for APD can be found on the HMRC website at http://customs.hmrc.gov.uk/channelsPortalWebApp/downloadFile?contentID=HMCE CL 000505 .
} 
$£ 10$. From November 1997 (as a result of Budget 1996), these rates were doubled to $£ 10$ and £20. From April 2001 (introduced in Budget 2000 by Gordon Brown), the structure was changed. Passengers travelling economy class pay $£ 5$ within the EU/EEA and $£ 20$ outside, whilst those travelling in higher classes pay $£ 10$ and $£ 40$ respectively. Table 5.5 summarises the rates over time.

The change to the structure of APD may have made it a less regressive tax, since distinction is made by class of flight as well as destination. The regressivity depends on the number of flights taken and the class and destination across the income distribution. Good estimates of the distributional effects of APD are therefore difficult to make, though given the overall size of the tax in revenue terms (see below), they are not likely to be that important in scale.

\section{Revenue}

APD is forecast to raise $£ 0.9$ billion in 2005-06 and $£ 1$ billion in 2006-07. This represents 0.2 per cent of total revenue in each year - clearly, APD is a relatively small tax in revenue terms. Figure 5.9 shows total revenues since 1994 in real terms (2004 prices). Clearly, the doubling of the rate in 1997 led to a surge in revenue, whilst the reforms of 2001 reduced revenues overall. This is not surprising since the majority of passengers travel economy class which means that any EU flights effectively had their APD halved by the reform.

Figure 5.10 shows the breakdown of passengers by APD liability for 2005 . These figures suggest total revenues for 2005 of $£ 910$ million, although provisional estimates for 2005 were for receipts of $£ 905$ million. The difference arises because of delays between when the flight is taken and when the tax is paid by the airline to the Treasury. Using the data in Figure 5.10, revenues for 2005 would have been around $£ 1.24$ billion, or 36 per cent higher, had the old regime of APD remained in place, assuming no change to passenger numbers. Indeed, APD receipts have

Figure 5.9

Real APD revenues

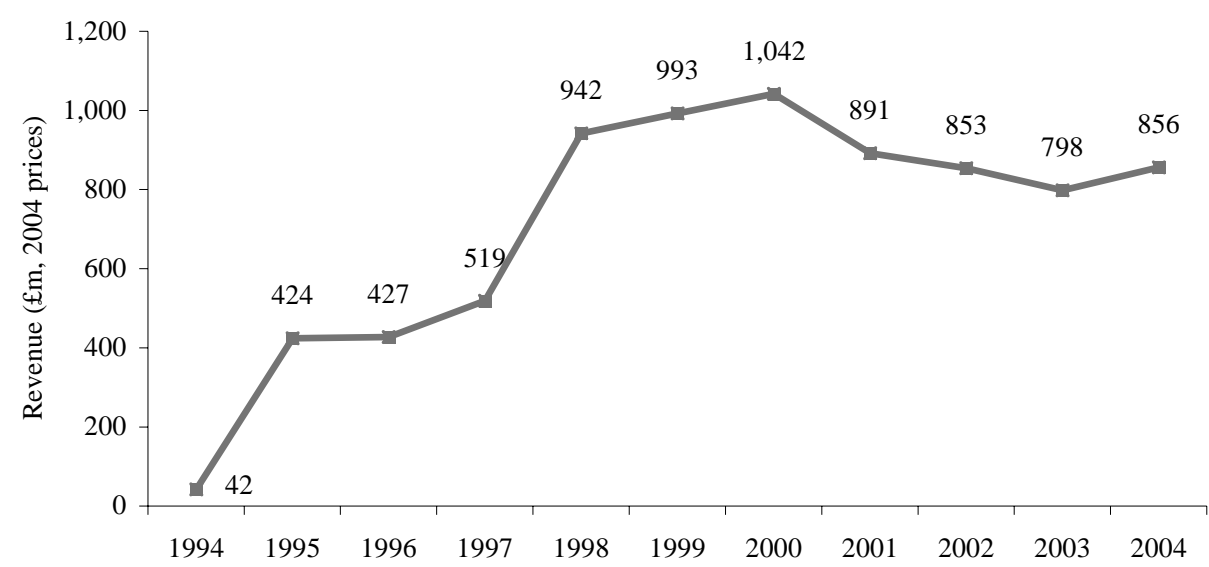


Figure 5.10

Chargeable APD passengers by amount payable, 2005 (provisional)

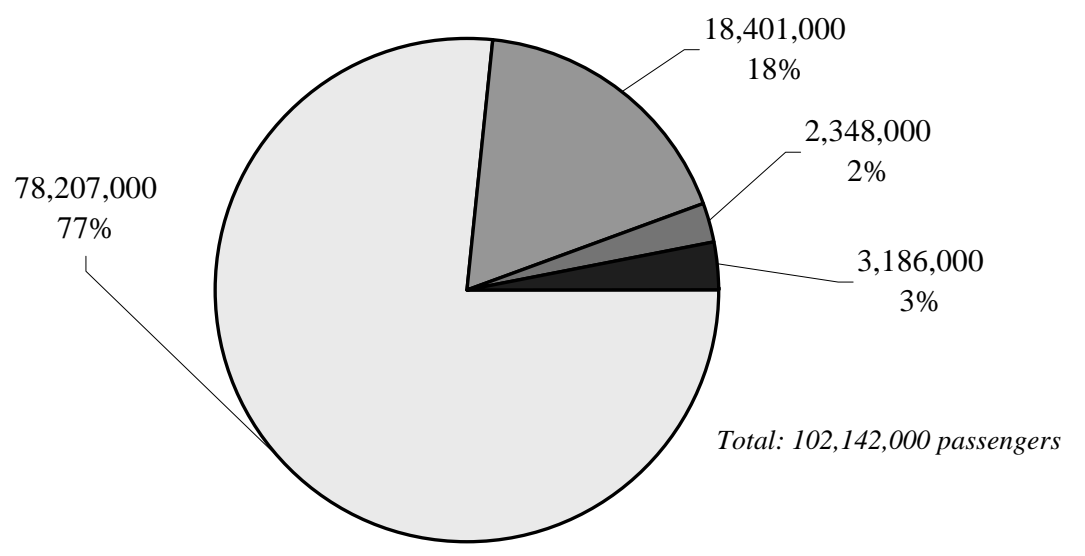

$\square$ Economy EU (£5) $\square$ Economy non-EU (£20) $\square$ Premium EU (£10) $\square$ Premium non-EU (£40)

Source: HM Revenue and Customs, 2006b.

declined in recent years despite a large rise in the total volume of chargeable passengers, from 58 million in 1997 to 102 million in 2005. Average APD receipts per passenger were £13.40 in 2001 and just £8.86 in 2005.

\section{$A P D$ as a green tax}

The definitional controversy aside, APD as currently designed could have environmental benefits. It increases the cost of flying to the consumer and as such will reduce marginal flights in much the same way that higher fuel duty reduces marginal car journeys. There is some scope for differentiating the tax according to class of flight - premium classes devote more room to each passenger, for example, such that fewer passengers can fly for a given journey. It also mitigates any distributional implications.

Estimates for the price elasticity of air travel are varied. Department for Environment, Transport and the Regions (2000) used an elasticity of -1.0 to estimate demand for flights up to 2020 (that is, assuming a 10 per cent increase in price reduces demand by 10 per cent). A Canadian review looking at 21 studies in Canada and abroad (Gillen, Morrison and Stewart, 2004) found that typical elasticities differ according to the type and length of journey. Business flights are the least elastic, a 10 per cent price rise reducing demand for long-haul business flights by around 2.5 per cent and for short-haul business flights by 7 per cent. Estimates for long-haul leisure flights vary widely but typically suggest a reduction in demand of around 10 per cent, whilst short-haul leisure flights can see falls in demand of around 15 per cent. Thus demand does appear quite sensitive to price, suggesting that there could be scope for using tax incentives to reduce demand for flights. 
APD appears not to cover the external costs of aviation, estimated by the Department for Transport and HM Treasury (2003) at $£ 1.4$ billion in 2000 for greenhouse gas emissions alone. Costs can only have risen with total emissions since then. This would appear to provide scope to raise the rates of APD, or to consider alternative ways of incentivising airlines to reduce emissions - the EU Commission has recommended bringing the airline industry into the EU Emissions Trading Scheme, for example. ${ }^{30}$ However, this looks unlikely to happen in the immediate future - evidence from the House of Commons Environmental Audit Committee (2006b) argues that aviation's inclusion will be in 2010 at the earliest, and more likely in 2013.

Emissions from aviation depend on the distance travelled and the fuel efficiency of the aircraft. Since the flight will generate roughly the same emissions whether one passenger flies or the craft is full, it would seem to make more sense to levy the tax on the flight rather than the passenger. The tax could be passed on to the consumer in the ticket price at the time of purchase, with airlines absorbing the tax for unfilled seats, for example. It would also be sensible to tax according to destination, as is currently the case, but with a more obvious link between distance and tax. A flight from London to Edinburgh, for example, attracts the same charge as a flight from London to Turkey (a member of the EEA). The charge could also vary according to the type of aircraft and its fuel efficiency, much in the same way as VED varies according to the emissions rating of the vehicle. This may encourage airlines to invest in more efficient aircraft in the longer term. Of course, environmental reasons for reforming the tax on a per-flight rather than perpassenger basis and for introducing distance- and efficiency-based differentials have to be balanced against additional complexity and confusion in the system.

Pearce and Pearce (2000) estimated the marginal external costs, both noise and pollution, of aviation at Heathrow Airport for various aircraft types and they recommended an optimal tax per 'aircraft movement' (arrival and departure). Their estimates suggest that the pollution component of such a tax would typically be 5 to 10 times larger than the noise component. Their figures suggest a tax of $£ 368$ for a short-haul A310 movement and of $£ 1,737$ for a long-haul movement on the same aircraft. For a Boeing 747-400, they suggest a short-haul tax of $£ 897$ and a longhaul tax of $£ 3,753$. On a per-passenger basis, these results suggest a tax of typically around $£ 3$ for short-haul destinations - slightly below the current EU rate of APD and $£ 15$ for long-haul destinations, slightly below the non-EU rate.

\subsubsection{Taxation of company cars}

\section{Background, structure and 'green' incentives}

Company cars provide a benefit in kind to employees either in addition to or in place of cash income. Such benefits in kind are taxed by allocating them a cash value. The way in which this is done for company cars can have important implications for the type of cars chosen, which in turn affects the environmental damage company cars will create.

Before April 1994, the 'income' value attributed to company cars depended on the age of the car, the size of the engine, the miles driven and the market value of

${ }^{30}$ See http://www.defra.gov.uk/environment/climatechange/trading/eu/future/index.htm. 
the car. For example, a car costing up to $£ 19,250$ which was less than four years old and with an engine size of 1,400cc or less would attract a taxable income value of $£ 2,310$ per year. If the engine size exceeded $2,000 \mathrm{cc}$, the income value was $£ 4,800$ per year. ${ }^{31}$ This system of 'scale charges' did not provide great incentives for employers to choose environmentally-friendly cars since the bands of engine sizes attracting the same scale charge were very wide. There was concern, therefore, that employers would choose cars for their employees that were less environmentally friendly than the cars the employees would have chosen for themselves.

In April 1994, the system changed such that the benefit was taken as 35 per cent of the list value of the car (with reductions if mileage exceeded 2,500 per year). This reduced incentives for employers to choose more polluting cars within any particular range of engine size and instead made the decision of which company car to purchase more in line with decisions about private cars. However, the system did not provide explicit incentives to choose less polluting cars.

In 2002-03 (announced in Budget 2000), the system was again reformed, to provide a more explicit environmental link to the benefit in kind assumed for company cars. ${ }^{32}$ Instead of taking 35 per cent of the list price, the percentage is lower for low-emissions vehicles - for example, in 2006-07, cars with an emissions rating of $144 \mathrm{~g}$ of $\mathrm{CO}_{2} / \mathrm{km}$ or less will be taxed at 15 per cent of the list price. This will provide incentives for employers to offer and employees to choose less polluting vehicles, and is broadly in line with the reforms of VED to an emissionsbased system. Table 5.6 shows the percentages applied to the list price of the car depending on the emissions rating for the financial years 2006-07 to 2008-09. Progressively, the system is designed to encourage lower-emissions vehicles over time as standards improve. However, it should be noted that if the car is taken in the highest-emissions class, there is no incentive to choose a vehicle at the lower end of the range. Further, the diesel supplement is a flat-rate 3 percentage points for most categories, which represents an extra 30 per cent over the petrol cost for the lowestemissions cars from 2008-09 but only an extra 10 per cent for cars with a current rating that gives them a 30 per cent of list price rating for petrol cars, for example. Since the maximum percentage of list price is capped at 35 per cent, the diesel supplement is zero for high-emissions vehicles. If the argument is that diesel cars have some fixed extra pollution from particulates, it would make more sense to have the diesel supplement as some fixed additional percentage of the petrol cost and not to cap at 35 per cent.

It is not just the provision of the car which is subject to taxation as a benefit in kind, but also the provision of fuel. Up to 2002-03, this was taxed using similar scale charges to those for the cars themselves with variations in the scale charge according to the engine size and type of fuel. For example, in 2002-03, a car with an engine of 1,401-2,000cc running on diesel would attract a fuel scale charge of $£ 2,850$ per year irrespective of how much fuel was actually provided; thus someone paying the 40 per cent income tax rate would pay tax of $£ 1,140(0.4 \times £ 2,850)$ for fuel, which may be considerably less than the fuel costs they would have paid

\footnotetext{
${ }^{31}$ For full details, see http://www.hmrc.gov.uk/stats/taxable benefits/table c1.pdf.

${ }^{32}$ Budget 2000 estimated this reform would generate $\mathrm{CO}_{2}$ emissions reductions of $0.5-1 \mathrm{MtC}$ per year by 2011-12.
} 
Table 5.6

Company car tax: percentage of list price taken as taxable benefit in kind

\begin{tabular}{|c|c|c|c|c|}
\hline Petrol car & Diesel car & 2006-07 & 2007-08 & 2008-09 \\
\hline $10 \%$ & $13 \%$ & - & - & $\leq 120 \mathrm{~g} \mathrm{CO}_{2} / \mathrm{km}$ \\
\hline $15 \%$ & $18 \%$ & $\leq 144 \mathrm{~g} \mathrm{CO}_{2} / \mathrm{km}$ & $\leq 144 \mathrm{~g} \mathrm{CO}_{2} / \mathrm{km}$ & $121-139 g$ \\
\hline $16 \%$ & $19 \%$ & $145-149 g$ & $145-149 g$ & $140-144 \mathrm{~g}$ \\
\hline $17 \%$ & $20 \%$ & $150-154 \mathrm{~g}$ & $150-154 \mathrm{~g}$ & $145-149 g$ \\
\hline $18 \%$ & $21 \%$ & $155-159 g$ & $155-159 g$ & $150-154 \mathrm{~g}$ \\
\hline $19 \%$ & $22 \%$ & $160-164 \mathrm{~g}$ & $160-164 \mathrm{~g}$ & $155-159 g$ \\
\hline $20 \%$ & $23 \%$ & $165-169 \mathrm{~g}$ & $165-169 \mathrm{~g}$ & $160-164 g$ \\
\hline $21 \%$ & $24 \%$ & $170-174 g$ & $170-174 \mathrm{~g}$ & $165-169 g$ \\
\hline $22 \%$ & $25 \%$ & $175-179 g$ & $175-179 g$ & $170-174 g$ \\
\hline $23 \%$ & $26 \%$ & $180-184 \mathrm{~g}$ & $180-184 \mathrm{~g}$ & $175-179 g$ \\
\hline $24 \%$ & $27 \%$ & $185-189 \mathrm{~g}$ & $185-189 \mathrm{~g}$ & $180-184 \mathrm{~g}$ \\
\hline $25 \%$ & $28 \%$ & $190-194 \mathrm{~g}$ & $190-194 \mathrm{~g}$ & $185-189 g$ \\
\hline $26 \%$ & $29 \%$ & $195-199 g$ & $195-199 g$ & $190-194 g$ \\
\hline $27 \%$ & $30 \%$ & $200-204 g$ & $200-204 g$ & $195-199 g$ \\
\hline $28 \%$ & $31 \%$ & $205-209 g$ & $205-209 g$ & $200-204 g$ \\
\hline $29 \%$ & $32 \%$ & $210-214 \mathrm{~g}$ & $210-214 \mathrm{~g}$ & 205-209g \\
\hline $30 \%$ & $33 \%$ & $215-219 g$ & $215-219 g$ & $210-214 \mathrm{~g}$ \\
\hline $31 \%$ & $34 \%$ & $220-224 \mathrm{~g}$ & $220-224 \mathrm{~g}$ & $215-219 g$ \\
\hline $32 \%$ & $35 \%$ & $225-229 g$ & $225-229 g$ & $220-224 \mathrm{~g}$ \\
\hline $33 \%$ & $35 \%$ & $230-234 \mathrm{~g}$ & $230-234 g$ & $225-229 g$ \\
\hline $34 \%$ & $35 \%$ & $235-239 g$ & $235-239 g$ & $230-234 \mathrm{~g}$ \\
\hline $35 \%$ & $35 \%$ & $240 \mathrm{~g}$ or more & $240 \mathrm{~g}$ or more & $235 \mathrm{~g}$ or more \\
\hline
\end{tabular}

Notes: A 3 percentage point supplement (to a maximum of 35 per cent of list price) applies for diesel cars to take account of higher pollutants from particulates which contribute to local emissions and respiratory diseases. This supplement does not apply if the diesel car meets Euro IV emissions standards (registered before 1 January 2006), although the supplement does apply to all diesel vehicles registered from 1 January 2006. Cars powered by environmentally-friendly fuel will be taxed at a discounted rate, e.g. electric cars see the percentage figure reduced by 6 points.

privately. This meant there was little incentive to conserve fuel consumption for people provided with fuel by their employers, although between 1998 and 2003 the scale charges were increased substantially in real terms in order to discourage employers from providing free fuel to employees.

From 2003-04, the system was changed so that the charge for employerprovided fuel is given by the same percentage calculated in Table 5.6 multiplied by $£ 14,400$. For example, a car with an emissions rating of $199 \mathrm{~g}$ of $\mathrm{CO}_{2} / \mathrm{km}$ will generate a fuel charge of $£ 3,744$ per year for petrol $(0.26 \times £ 14,400)$ or $£ 4,176$ per year for diesel $(0.29 \times £ 14,400)$. This gives a further incentive to provide lowemissions vehicles. The aim of the changes has been to make free fuel provided by employers unattractive for the majority of employees. For employees that do take the free fuel, the incentive is to drive as much as possible to benefit from it, perhaps 
making unnecessary journeys, since the marginal cost of driving is zero. Also, the system will make it more likely that less fuel-efficient cars will still have the incentive to take free fuel since the private cost of purchasing fuel is higher the less fuel-efficient is the car. Take an example where the employee pays tax at 40 per cent and has a petrol-fuelled company car which pollutes at $190 \mathrm{~g}$ of $\mathrm{CO}_{2} / \mathrm{km}$. This means the fuel scale charge is $£ 3,600$ per year $(0.25 \times £ 14,400)$ and the tax payable is therefore $£ 1,440$ per year $(0.4 \times £ 3,600)$. Suppose fuel costs $90 \mathrm{p} /$ litre and the car's fuel efficiency is 40mpg. It will be worth taking employer-provided free fuel only if the distance driven each year exceeds around 14,000 miles - less than that and the cost of purchasing fuel privately will be less than the tax liable. However, if the efficiency of the car is only 30mpg, then this threshold is only around 10,500 miles per year.

\section{Beneficiaries, revenues and effects}

The numbers of people receiving company cars and free fuel have been in decline since the early 1990s. In 1992-93, for example, 1.81 million people received a company car and 910,000 people free employer-provided fuel (see page 105 of Smith (1995)). In 2004-05, however, estimates suggest that only 1.24 million people received a company car and 420,000 free fuel. ${ }^{33}$ This represents a fall of about one-third in car recipients and one-half in fuel recipients. The decline in fuel receipt has been particularly steep, reflecting the large increase in scale charges in the late 1990s and the reform of the system towards an emissions-based system in 2003-04.

The taxation of company cars and fuel represents income tax from a benefit in kind - in the absence of company cars and free fuel, wages may be higher such that tax revenues would be unchanged. Indeed, the most recent HMRC evaluation (see below) estimates that reforms to the system since 2002 have cost the exchequer around $£ 120-£ 140$ million per year since 2003-04 by encouraging the purchase of lower-emissions vehicles. The reforms have clearly given the tax a greener hue: the incentives inherent are either not to provide the car/fuel at all or to provide greener models where they are still given as perks. The total tax liability for 2004-05 is estimated at $£ 1.5$ billion for cars and $£ 0.4$ billion for fuel.

Data from the Society of Motor Manufacturers and Traders Ltd (2006) show that newly-purchased company cars tended to have slightly lower emissions than newlypurchased private cars (167.1g of $\mathrm{CO}_{2} / \mathrm{km}$ and $172.3 \mathrm{~g}$ of $\mathrm{CO}_{2} / \mathrm{km}$ respectively). Since company cars make up around 56 per cent of all new cars sold, the incentives built into the system of taxation may be particularly important for reducing the average emissions rating of the new car stock in the UK. This does suggest, however, that if the system encourages people to buy private cars rather than company cars, there is a danger that people will choose slightly more polluting vehicles privately than they would have received as a company car, which could increase overall emissions. In 2004, the (then) Inland Revenue carried out an assessment of the impact of the changes to company car taxation, ${ }^{34}$ and an update to the report was carried out by HMRC for Budget 2006. ${ }^{35}$ The latter report suggests

\footnotetext{
${ }^{33}$ See HMRC statistics: http://www.hmrc.gov.uk/stats/taxable benefits/4 5 mar06.pdf.

34 Inland Revenue, 2004.

35 HM Revenue and Customs, 2006a.
} 
that current emissions reductions resulting from the scheme are around $0.25 \mathrm{MtC}$, rising to $0.4-0.9 \mathrm{MtC}$ by the end of the next decade, achieved by reducing the average emissions from company cars by $15 \mathrm{~g}$ of $\mathrm{CO}_{2} / \mathrm{km}$ over and above what would have happened without the reform. This has been more than enough to offset potential increases in emissions from people switching from company cars to private cars. ${ }^{36}$ The report also notes that around $70-100$ million fewer private miles are now being driven as a result of the decline in free fuel provision - however, this represents just 0.1 per cent of all miles driven in the UK since so few people are now in receipt of free fuel via their employer.

\subsection{Taxes on waste and natural resources}

\subsubsection{Landfill tax}

\section{Background and structure}

The landfill tax was originally announced in the November 1994 Budget and was implemented from October 1996. ${ }^{37}$ The November 1995 Budget described it as a tax 'designed to use market forces to reduce the environmental damage associated with waste disposal' (HM Treasury, 1995). As such, it is clear that it was introduced explicitly as an environmental tax. If the only concern about landfill were a reduction in the space available (the number of working landfill sites declined from 3,400 in 1994 to 2,200 in April 2005, though each site was larger), then we would expect market forces to raise the price of landfill and encourage those using it to find alternatives. However, if there are external costs of landfill, then there is scope for the government to intervene and levy a charge such as the landfill tax. The Department for Environment, Food and Rural Affairs (2006) suggests that landfill accounted for almost 40 per cent of total UK methane emissions in 2004, or about 3 per cent of all greenhouse gas emissions that year. Other externalities associated more directly with landfill include the risk of contamination of water systems, costs from transporting waste to landfill sites and the disutility to local residents of the landfill sites (through noise, smell, etc.). Department for Environment, Food and Rural Affairs (2003) suggested the 'fixed' cost of landfill sites through these sorts of channels amounted to around £1.52 to £2.18 per tonne of landfill. Further, there are possible health effects - a study sponsored by the Department of Health (2001) found a very small increased risk of birth defects for those living within $2 \mathrm{~km}$ of landfill sites, for example. In 1993, the then Department of the Environment suggested that incinerating waste yielded a net social benefit of some £5-£8 per tonne relative to landfill. There would therefore appear to be a case for a levy like the landfill tax in principle.

Around the time of the introduction of the landfill tax, CSERGE, Warren Spring Laboratory and EFTEC (1993) carried out a study of the marginal external costs of landfill, including global pollution from $\mathrm{CO}_{2}$ and methane, transport and leaching

\footnotetext{
${ }^{36}$ Much of the HMRC analysis was based on surveys carried out by the independent research firm BRMB. These surveys suggested that, on average, people would choose a car with an emissions figure around $5 \mathrm{~g}$ of $\mathrm{CO}_{2} / \mathrm{km}$ higher than that for their current company car if the company car were no longer provided.

${ }^{37}$ Details of the background to the landfill tax can be found in Davies and Doble (2004).
} 
into the water supply. Estimates ranged from around $£ 1$ to $£ 9$ per tonne depending on whether the landfill was urban or rural and whether there was energy recovery. In addition, estimates of the marginal disamenity costs to households were made of $£ 2$ per tonne (similar to the 2003 DEFRA figures). On average, the marginal costs were estimated at $£ 7$ per tonne for active waste and $£ 2$ per tonne for inert waste, matching the initial rates of the landfill tax in 1996 (see below).

The landfill tax is levied on any organisation or local authority that wishes to dispose of waste in landfill sites. In principle, the tax is incident on the landfill site owners, though the costs are passed on to users in the form of higher prices. On its introduction, the landfill tax was set at two rates: a reduced rate of $£ 2$ per tonne and a standard rate of $£ 7$ per tonne. ${ }^{38}$ The reduced rate applies to inactive or inert wastes and covers such things as rocks and soil, ceramic materials, minerals, ash and water. ${ }^{39}$ This distinction reflects the fact that inert wastes are likely to have much lower environmental-based landfill externalities, although the local area externalities will remain such that some tax is still justified. Since the tax's introduction, the reduced rate has remained unchanged, but the standard rate has increased considerably since 1999 when a 'landfill tax accelerator' was implemented. This saw the standard rate rise by $£ 1$ per year until 2004 after an initial rise to $£ 10$ in 1999. In the 2002 Pre-Budget Report, the accelerator was raised to $£ 3$ per year from 2005, with a medium-term objective to reach a rate of $£ 35$ per tonne. The current rate (since April 2006) is £21 per tonne, three times the starting value. Table 5.7 summarises the history of landfill tax rates since the tax was introduced.

Table 5.7

Rates of landfill tax (£/tonne)

\begin{tabular}{l|rr}
\hline & Standard rate & Reduced rate \\
\hline October 1996 & $£ 7$ & $£ 2$ \\
April 1999 & $£ 10$ & $£ 2$ \\
April 2000 & $£ 11$ & $£ 2$ \\
April 2001 & $£ 12$ & $£ 2$ \\
April 2002 & $£ 13$ & $£ 2$ \\
April 2003 & $£ 14$ & $£ 2$ \\
April 2004 & $£ 15$ & $£ 2$ \\
April 2005 & $£ 18$ & $£ 2$ \\
April 2006 & $£ 21$ & $£ 2$ \\
\hline
\end{tabular}

Note: The standard rate is expected to increase by at least $£ 3$ per year to a medium-term target rate of $£ 35$ per tonne under the landfill tax accelerator.

Source: HM Revenue and Customs, 2006f.

\footnotetext{
${ }^{38}$ At the same time, employers' National Insurance contributions were reduced to offset the cost. The aim was to make the overall tax burden similar but shift the focus from labour to waste disposal. Budget 2003 announced that further rises in the rate of landfill tax would be implemented in such a way as to leave the overall burden on business unchanged - in 2005, the Business Resource Efficiency and Waste (BREW) programme was launched to recycle landfill receipts to businesses through advice and support about resources and waste efficiency and R\&D project funding.

${ }^{39}$ A full list of wastes that attract the reduced rate, and a full discussion of the operation of landfill tax, can be found in HM Revenue and Customs (2004a).
} 
Early reports on the effects of the landfill tax (see, for example, House of Commons Environment, Transport and Regional Affairs Committee (1999) and Martin and Scott (2003)) suggested that at initial rates, the tax was making very little difference to the behaviour of firms and local authorities. However, this need not be a cause for concern - recall that the rates were based on best estimates of the marginal externality and so the lack of response merely suggests that the elasticity of waste disposal is quite low. Clearly, though, the tax alone at those initial rates would not have been sufficient to meet the EC Directive targets (see Box 5.2). The new higher rates and medium-term target rate of the tax suggest it is seen not just as a means to recover externalities but also to change behaviour and meet these targets. From an economic perspective, however, it may be that these targets are too severe, in the sense that they demand a level of landfill far below that which would be achieved by an 'optimal' landfill tax designed only to internalise the external costs.

\section{Box 5.2}

\section{The European Landfill Directive \& LATS}

The landfill tax may help the UK meet international obligations to reduce biodegradable municipal waste (that which is largely responsible for methane emissions) sent to landfill to 75 per cent of the 1995 level by 2010, 50 per cent of the 1995 level by 2013 and 35 per cent of the 1995 level by 2020. These targets were set under the 1999 European Landfill Directive (99/31/EC).

As a further method to help meet this target, the government announced in the 2003 Waste and Emissions Trading Act that a system of tradable permits for landfill of biodegradable municipal waste would be set up from 1 April 2005. Called the Landfill Allowance Trading Scheme (LATS), the system allocates a quota of landfill tonnage to each local authority in England for each year up to 2020 . $^{2}$ Permits totalling around 15.6 million tonnes of biodegradable waste were allocated for the base year (2005), and allocations for the final year (2020) total 5.2 million tonnes, implying a reduction of around two-thirds, in line with the EC Directive. Authorities are allowed to bank, buy and sell permits ${ }^{\mathrm{b}}$ and are fined $£ 150$ per tonne if they do not have enough permits to meet their landfill totals in each year. This system represents another move towards the use of permit-based systems as either a complement to or a replacement of tax-based systems in meeting environmental objectives.

Budget 2006 reported that the first year of LATS generated sales of 455,000 allowances at a value of $£ 9.6$ million, representing an average transaction price of around £21 per allowance - the same amount as the current rate of landfill tax.

More details of LATS can be found at http://www.defra.gov.uk/Environment/waste/localauth/lats/index.htm. Barrow (2003) looked at some of the economic issues surrounding the scheme prior to its introduction and suggested that the costs of meeting the EU targets could be significantly reduced as a result, though the estimated savings were very uncertain.

\footnotetext{
${ }^{a}$ A full list of these quotas can be found at http://www.defra.gov.uk/Environment/waste/localauth/lats/pdf/tableb-latsallocat\%20.pdf.

${ }^{\mathrm{b}}$ Banking of permits means that unused permits from one year can be carried over to the next, up to the next target year (when assessments of whether the UK is meeting its Landfill Tax Directive objectives are made). Authorities are also allowed to 'borrow' up to 5 per cent of their next year's allowance against current-year landfill.
} 
At the same time as the landfill tax was introduced, the government established the Landfill Tax Credit Scheme (LTCS). ${ }^{40}$ This was designed so that landfill operators could donate to approved bodies undertaking approved projects and in return receive a credit of 90 per cent of the value of their donation from their landfill tax bill, up to a fixed limit (equal to 6 per cent of the total liability for 2006-07). Approved projects fall into one of six categories - land reclamation, land pollution reduction, provision of public amenities close to a landfill site, conservation of habitats, restoration of religious buildings or sites of historical interest close to landfill sites and funding the cost of services to environmental bodies. By December 2005, almost $£ 800$ million had been donated to projects through this scheme. However, the LTCS has had several critics (for example, Morris and Read (2001)), who argue that it is unnecessarily complex and administratively burdensome. There may be an argument that if the projects mitigate the environmental externalities of landfill, then there is scope to have a credit scheme of this sort, though an alternative funding route may be through central or local government directly using the additional landfill tax revenues. Budget 2006 increased the value of the LTCS to £60 million for 2006-07.

\section{Revenues and landfill volumes}

The 2006 Budget estimates revenues from the landfill tax of $£ 700$ million in 200506 and forecasts revenues of $£ 800$ million for 2006-07. These represent 0.1 per cent and 0.2 per cent of total revenues in each respective year. Figure 5.11 shows revenues from 1996 to 2004 in 2004 prices. Revenues have been rising fairly steadily since the rate of landfill tax began to rise in 1999, and with larger planned increases under the landfill tax accelerator it seems that landfill tax will play an increasingly important role in total revenues in years ahead, though clearly it will only ever represent a tiny fraction of total revenues.

Total waste disposed of under the landfill tax scheme has fallen from around 99.3 million tonnes in 1997 to 71.5 million tonnes in 2005. Of the 2005 figure, around 43.6 million tonnes (61 per cent) was charged at the standard rate and 11.8 million tonnes (17 per cent) at the reduced rate; 16.1 million tonnes (23 per cent) was exempt. ${ }^{41,42}$

Figures for municipal waste (that is, that disposed of by local authorities) for England from DEFRA ${ }^{43}$ show what has happened both to total municipal waste and the total volume landfilled since the tax came into force. Figure 5.12 gives total waste and total landfill on the right-hand axis and breaks down the total waste into the means by which it was disposed of on the left-hand axis. From around 84 per cent of waste being landfilled in 1996-97 and 7 per cent being recycled or composted, by 2004-05 the figures were 67 per cent and 24 per cent respectively. Incineration has typically accounted for 8-9 per cent of disposal across the whole period, so it appears that there has been a direct switch of around 17 per cent of waste from landfill to recycling. In absolute terms, however, the amount of waste going to landfill only began to fall in 2002-03 - total landfill rose by about

\footnotetext{
${ }^{40}$ For full details and information, see http://www.Itcs.org.uk/default.asp.

41 HM Revenue and Customs, $2006 \mathrm{f}$.

42 Exemptions are in place for waste from inland waterways through dredging, mining and quarrying waste and pet cemeteries.

${ }^{43}$ See http://www.defra.gov.uk/environment/statistics/wastats/index.htm\#wastedataflow.
} 
1.8 million tonnes between 1996-97 and 2001-02 and has since fallen by around 2.5 million tonnes. This is because total waste produced has continued to rise over the period, from 24.6 million tonnes in 1996-97 to 29.7 million tonnes in 2004-05. It does seem, though, that the landfill tax started to 'bite' only after the accelerator

Figure 5.11

Landfill tax revenues

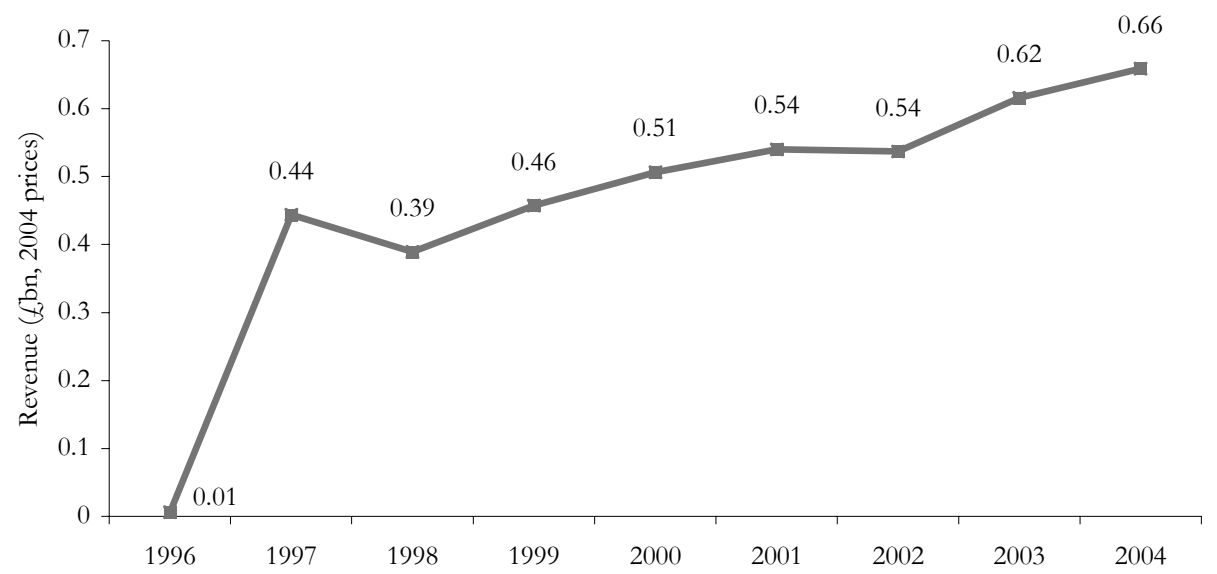

Note: Figures for 1996 are low because the tax only came into force in October 1996 and there were no receipts until November 1996.

Source: HM Revenue and Customs, $2006 f$.

Figure 5.12

Total municipal waste, landfill and other means of disposal

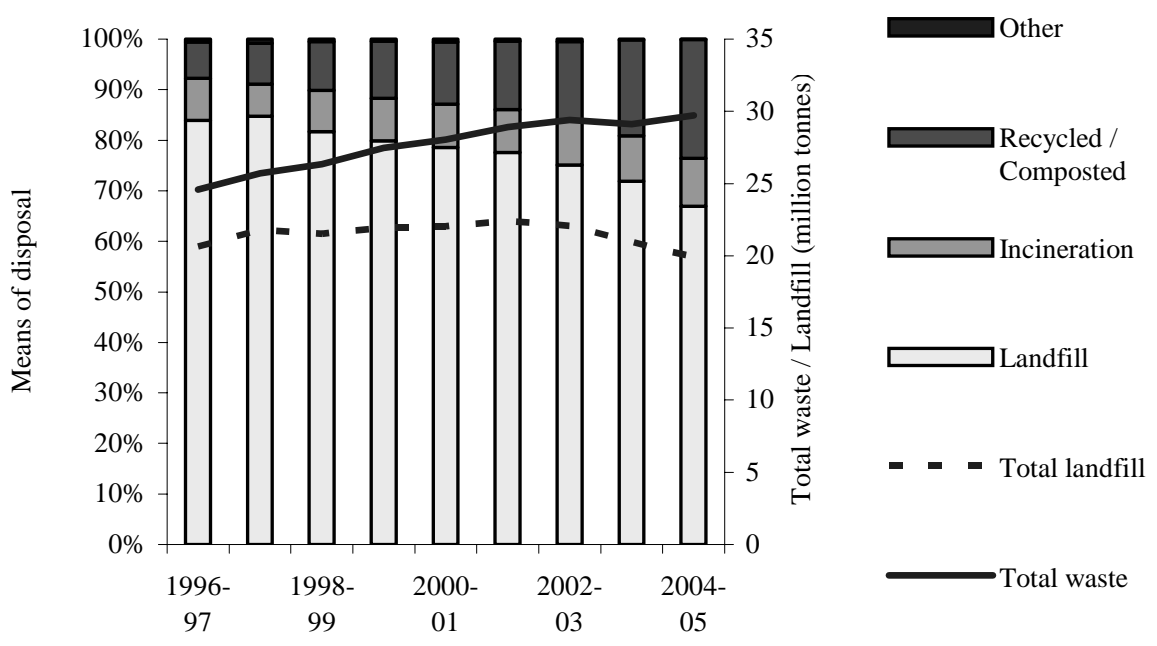

Source: Compiled from DEFRA Waste Management Statistics, various years. 
was implemented. How much of the change is directly attributable to the tax is, of course, hard to discern; changes in local council policy towards recycling (driven by the EC Directive) may have been a factor, as might changes in consumer attitudes.

Also in Figure 5.12, note an interesting rise of around 1 million tonnes of landfill in the year immediately after the tax was introduced. Reports at the time suggested this may have been due to commercial waste being dumped on local authority sites for municipal disposal - so-called 'fly-tipping' (see, for example, Morris and Read (2001)). Even if this were the case, it seems that the problem has been reduced in recent years.

\section{The future of landfill tax}

It seems clear that landfill tax is here to stay and that the rate will rise quite substantially in future years. Having already tripled from its initial rate, the medium-term strategy is for a rate of $£ 35$ per tonne for standard waste, $£ 14$ (or 67 per cent) higher than the current rate. If rates are raised by $£ 3$ per tonne per year as planned, the landfill tax will reach its medium-term target rate in 2011-12. Beyond that, it is not clear what the strategy will be - much will depend on progress towards hitting the targets laid out in the EC Directive and the contribution made to that by the Landfill Allowance Trading Scheme. As for the Landfill Tax Credit Scheme, it seems that although the scheme will remain, its importance is being reduced, since the cap on the share of total revenues that can be reclaimed through it has been substantially reduced: in 1996-97, operators could reclaim up to 20 per cent of their liabilities through this scheme; this was reduced by two-thirds from 2003 and has since been gradually eroded further to 6 per cent. The extra monies not reclaimed were used in part by the government to fund directly a waste management programme aimed at reducing household waste levels and improve access to recycling facilities.

\subsubsection{Aggregates levy}

\section{Background, structure and design}

The aggregates levy was introduced in April 2002, having been announced in Budget 2000 as a charge that

will ensure that the environmental impacts of aggregates production not already addressed by regulation are more fully reflected in prices, encouraging a shift in demand away from virgin aggregate towards alternative materials such as recycled aggregate.

HM Treasury, 2000

'Aggregates' for the purposes of the levy refer to rock, gravel or sand and any materials naturally mixed with them. The levy is charged on quarry operators and other organisations that commercially exploit aggregates, at a rate of $£ 1.60$ per tonne. This rate has remained unchanged since the levy was introduced - Budget 2006 stated that in principle the rate should rise in line with inflation each year, but that because the system was still 'bedding in', the rate would remain unchanged. ${ }^{44} \mathrm{~A}$

\footnotetext{
${ }^{44} \mathrm{Had}$ the rate of the levy risen by 2.5 per cent each year since introduction, broadly in line with inflation, the rate for 2006-07 would be around $£ 1.77$ per tonne instead of $£ 1.60$.
} 
special system is also in place for Northern Ireland, where there was concern that aggregates could be brought in from the Republic of Ireland, leading to a competitive disadvantage for UK businesses. So long as the aggregate is both extracted and exploited in Northern Ireland, the levy is subject to an 80 per cent discount, leaving the rate at 32p per tonne. This is due to remain until 2011. Campaign groups such as Friends of the Earth have called for the levy to be applied at the full rate in Northern Ireland. ${ }^{45}$

Not all aggregates are subject to the levy - clay and coal, for example, are not taxable - and in certain cases, depending on what use the aggregate is to be put to, exemptions may apply. If the aggregate is to be supplied to people outside the UK, then the levy is refundable, and any aggregates imported from outside the UK become subject to the levy once they are commercially exploited. ${ }^{46}$

As with the landfill tax, the economic rationale for an aggregates levy does not lie in concerns about scarcity - this would be dealt with through the price mechanism, with reduced supply raising the price without the need for government intervention. Instead, the levy is justified by the presence of external costs of aggregates extraction. A report by London Economics commissioned by the ODPM in $1999^{47}$ suggested that the total external costs of aggregates extraction were in the region of $£ 380$ million per year. These externalities include things such as emissions from transportation, noise, dust, pollution of groundwater, loss of habitat for wildlife and so on. Estimates from contingent valuation (CV) studies ${ }^{48}$ for the report suggested that the average externality amounted to around $£ 0.35$ per tonne of crushed rock extracted for those living near rock quarries, £2 per tonne of sand and gravel for those living near affected sites and $£ 10$ per tonne of aggregates extracted from National Parks. This suggests that the optimal rate of the levy should vary with the type of material extracted and also possibly with the location of extraction. However, this may create administrative and enforcement difficulties, though it should be borne in mind that there are differentials of a similar nature in other taxes such as the landfill tax.

The levy was, perhaps unsurprisingly, opposed by those involved in the commercial exploitation of aggregates. A report for the British Aggregates Association in $2005^{49}$ suggested there may be unintended consequences of the levy which could mitigate its environmental impact. In particular, the report highlights the fact that secondary aggregates, such as power-station ash and slag, that can be used in construction and which are not subject to the levy become relatively cheaper and therefore more economically viable. Since the sources of these materials tend to be further from construction markets than the primary, taxed materials, there may be additional transport costs and externalities from moving the untaxed materials to the construction sites. However, the key question is what would have happened to these

\footnotetext{
${ }^{45}$ See, for example, http://www.foe.co.uk/resource/briefings/aggregates levy ni.pdf. Though there is an argument for exemptions or variations in tax rates to take account of particular circumstances, there may be unintended consequences of such a policy - for example, providing incentives for some businesses to relocate to Northern Ireland to take advantage of the reduced tax rate.

${ }^{46}$ Full details of exemptions, reliefs and the workings of the aggregates levy can be obtained from $\mathrm{HM}$ Revenue and Customs (2004b).

47 Office of the Deputy Prime Minister, 1999.

48 In these studies, surveys are carried out to assess how much people are willing to pay to reduce environmental externalities in order to arrive at a valuation for them.

49 BDS Marketing \& Research Ltd, 2005.
} 
secondary aggregates in the absence of the levy - would there have been larger external costs if they were disposed of in another way rather than being used in construction? Further, the costs of any additional road transport externalities will be reflected in motor fuel taxes.

There is no international pressure to reduce the level of aggregates extraction as there is to reduce landfill, and given the fact that the aggregates levy has remained unchanged since introduction and there seems little prospect of it increasing substantially in the near future, it could perhaps be argued that the aim of the tax appears to be internalising external costs (current revenues broadly match the estimates of the total external cost, though, as noted repeatedly, this does not imply the current value of the tax is 'efficient'). It is not a revenue-raising tax in and of itself since it was offset by a reduction in employers' National Insurance contributions when implemented - indeed, most estimates suggest that this tax reduction more than offset the revenues obtained from the new levy, reducing total business taxation. ${ }^{50}$

As part of the aggregates levy, the Aggregates Levy Sustainability Fund (ALSF) was established which ring-fenced part of the revenue from the levy to pay for projects to minimise the demand for aggregates, promote environmentally-friendly aggregates extraction and reduce the local effects of extraction. In principle, this is similar to the Landfill Tax Credit Scheme, but the revenues are channelled through government payments rather than being recouped by the operators in return for private investment. An evaluation of the ALSF by the Department for Environment, Food and Rural Affairs (2003b) suggested that one of the reasons for having such a fund was to try to overcome the imprecision in targeting externalities that comes from having a single rate of tax - presumably by targeting more of the money where the externality is deemed to be greater. The ALSF was due to end in 2004, but the 2003 Pre-Budget Report extended the scheme for a further three years.

\section{Revenue and trends in aggregates extraction}

Real-terms revenue (2004 values) for the levy amounted to $£ 172$ million in 2002, $£ 348$ million in 2003 and $£ 334$ million in $2004 .^{51}$ Forecasts from the 2006 Budget were that revenues would be $£ 300$ million in both 2005-06 and 2006-07. This represents less than 0.1 per cent of total revenues in each year.

The total amount of aggregates extracted fell from 266.4 million tonnes in 2003 to 261.8 million in 2005, of which around 38.1 million was relieved of the levy (for example, because it was exported) and 23.5 million was exempt. ${ }^{52}$ Using longerterm data from ONS's Environmental Accounts, total domestic extraction of sand, gravel and crushed stone fell from 340 million tonnes in 1990 to 271 million tonnes in 2002, the year the levy was introduced. This represents a fall of around 20 per cent over that period, or around 2 per cent per year. Since 2002, domestic extraction has fallen further, to 265 million tonnes in 2004. This represents a fall of around 1.1 per cent per year since the levy was introduced, suggesting that the rate of decline in

\footnotetext{
50 See, for example, various Parliamentary Answers such as those given on 1 April 2004 at http://www.publications.parliament.uk/pa/cm200304/cmhansrd/vo040401/text/40401w36.htm, which demonstrate that both the aggregates levy and the climate change levy generate less in receipts than the revenue loss from reduced employer National Insurance contributions that supposedly made each revenueneutral.

${ }^{51}$ Author's calculation from HM Revenue and Customs (2006c).

52 HM Revenue and Customs, 2006c.
} 
extraction has fallen. The British Aggregates Association (2005) suggested that both the aggregates levy and the landfill tax have contributed towards the decline in aggregates extraction, the latter because increased waste disposal costs have encouraged the re-use of hard core and other inert wastes instead of virgin aggregates in road-building, etc.).

Budget 2006 suggested that primary aggregates sales fell by 8 per cent between 2001 and 2003 despite a buoyant construction industry. Although this may have been partly due to the aggregates levy, it is unlikely to have been the whole story between 1994 and 1996, for example, sales of aggregates fell by around 20 per cent despite recovery in the construction industry at the time. The key question is, of course, what extraction rates would have been in the absence of the levy, and this is hard to assess.

\section{The future of the aggregates levy}

Although it seems unlikely the aggregates levy will be abolished, there appears to be little sign that either the rate or structure of it will significantly change in the immediate future. The government has left the rate unchanged for four years. Any change is likely to represent a 'correction' for inflation - a precedent exists in the climate change levy, which was kept at the same nominal value between 2001 and 2006.

\subsubsection{Water abstraction}

Water abstraction charges are levied on businesses that extract and use overground or underground water sources, including tidal water. The charges are levied by the Environment Agency and are designed to cover its costs of water resource management. ${ }^{53}$ As such, they cannot be thought of explicitly as an environmental tax. In addition, the charge is levied on the basis of the amount of water licensed to be abstracted, rather than the actual amount abstracted (in 2003, for example, around 58.6 million litres of water per day were actually abstracted from surface and groundwater sources, but abstraction licences for 126.6 million litres per day were granted). Environmental consequences would be felt on actual abstraction rather than on licensed abstraction.

Although the charges will affect the decision of firms to extract water at all, or how much to extract, relative to them not being levied at all, they are not intentionally designed for environmental reasons. Water resources are, of course, limited, and so the charges can be seen as a way to prevent over-exploitation of a common property resource. Further, in certain areas and for certain uses, water abstraction may have environmental consequences - English Nature and the Environment Agency reported in 2000 on the possible effects on 26 Sites of Special Scientific Interest (SSSIs) due to water abstraction in England. ${ }^{54}$ Smith (1995) suggests three possible environmental externalities also resulting from water abstraction - groundwater abstraction leading to sea water penetrating aquifers in coastal areas; abstraction from lakes and rivers reducing their ability to assimilate pollutants; and water returned from cooling stations having negative environmental

\footnotetext{
${ }^{53}$ See http://publications.environment-agency.gov.uk/pdf/GEHO0306BKKD-e-e.pdf, which also estimates the revenues from licensing in 2006-07 at £128 million.

${ }^{54}$ See English Nature press release at http://www.english-nature.org.uk/news/story.asp?ID=66.
} 
impacts. A study by Risk and Policy Analysts Ltd (2000) estimated for various sites external costs of between 3 and 15 pence per cubic metre of water extracted. The same study also argued, however, that the responsiveness of businesses to the price of abstraction was typically very low and that implementing an environmentallyrelated charge in the abstraction costs would therefore not change firm behaviour. In principle, just because demand elasticities are low does not mean that using taxes to cover external costs is undesirable - all it means is that the difference between the socially optimal level of abstraction and the privately optimal level is small enough that the efficiency benefits would be low. Although including environmental charges in abstraction costs would be desirable under the 'polluter pays principle' (PPP), there may be inefficiencies from doing so to the extent that the external costs are likely to be highly variable across location and time. ${ }^{55}$ Unless they could be introduced on a variable basis using good evidence of where externalities were higher and lower, a more effective mechanism might be direct regulation to limit or prevent abstraction from certain areas.

\section{Current charges}

As a result of the Water Act 2003, people abstracting less than $20 \mathrm{~m}^{3}$ per day typically do not need a licence. Larger volumes require a licence from the Environment Agency. The charge includes an administration charge to process the licence application, and then an annual charge which depends on the volume of water to be abstracted that has been applied for, the region in which the abstraction will take place, the time of year during which abstraction will occur, the amount of water expected to be lost (i.e. not returned to the source) and the source of the water. Regional variations in the charge reflect regional differences in the cost of water resource management, whilst seasonal, loss and source factors reflect the effects of different uses on water availability.

The total charge is determined by multiplying the regional charge by the volume, and then multiplying the result by the source factor, season factor and loss

Table 5.8

Regional water abstraction charges, 2006-07

\begin{tabular}{l|r}
\hline Region & Standard unit charge $\left(\boldsymbol{£} / \mathbf{1}, \mathbf{0 0 0 \mathbf { m } ^ { 3 } )}\right.$ \\
\hline Anglian & 23.35 \\
Midlands & 13.28 \\
Northumbria & 24.27 \\
North West & 12.34 \\
Southern & 17.36 \\
South West / Wessex & 19.06 \\
Thames & 12.39 \\
Yorkshire & 10.33 \\
Environment Agency Wales & 12.18 \\
\hline
\end{tabular}

\footnotetext{
${ }^{55}$ Department for Environment, Food and Rural Affairs (2001a) argues that 'a charging scheme set above cost-recovery levels would be too unwieldy in operation and too imprecise to be effective as means of significantly reducing abstractions'.
} 
Table 5.9

Source, season and loss factors for water abstraction, 2006-07

\begin{tabular}{ll|r}
\hline Source factor & Unsupported & 1.0 \\
& Supported & 3.0 \\
& Tidal & 0.2 \\
Season factor & Summer & \\
& Winter & 1.6 \\
& Whole year & 0.16 \\
& & 1.0 \\
Loss factor & High (e.g. spray irrigation) & 1.0 \\
& Medium (e.g. private and public water supply) & 0.6 \\
& Low (e.g. mineral washing) & 0.03 \\
& Very low (e.g. power generation, fish farms, water meadows) & 0.003 \\
\hline
\end{tabular}

Notes: Certain rivers are 'supported sources'; all other non-tidal sources are 'unsupported'. Full details of the operation of the charges can be found in Environment Agency (2006).

factor. A minimum charge of $£ 25$ applies. Tables 5.8 and 5.9 show the 2006-07 values of these charges and factors.

Taken together, these charges imply that for a firm in the North West region abstracting $100,000 \mathrm{~m}^{3}$ of water per year at medium loss from an unsupported source across the whole year would pay a charge of $£ 740.40(100 \times £ 12.34 \times 0.6 \times 1.0 \times 1.0)$. In 1995-96, the same firm would have faced a charge of $£ 478.80$ which, adjusted for inflation, is $£ 627.26$ in 2006-07 prices. This suggests abstraction charges (for this particular example) have risen in real terms by an order of around 20 per cent since 1995-96, though, as cautioned above, this should not be taken as a sign that attempts are being made to use the abstraction charge system as an environmental tax per se. Despite this real-terms rise, actual abstractions from ground and surface water sources have typically averaged around 60 million litres per day since 1990.

\section{Box 5.3}

Water abstraction licence trading ${ }^{a}$

As part of the Water Act 2003, a system of licence trading for water abstraction permits came into force on 1 April 2006. This was developed after a wide consultation into the use of economic instruments in water abstraction (see, for example, Department for Environment, Food and Rural Affairs (1998, 2001a and 2001b)) and represents another step towards trading mechanisms being used in government environmental policy. The system is not quite a system of tradable permits like the UK ETS or the LATS, since holders of abstraction licences are not free to sell them to other registered parties - all trades must be first approved by the Environment Agency and any trades that may result in environmental damage will not be approved.

\footnotetext{
${ }^{\mathrm{a}}$ Further information can be found at http://www.waterlicences.co.uk.
} 


\subsection{Taxes on energy}

Energy production is a major source of UK greenhouse gas emissions. Figures from the DTI publication Energy Trends for March 2006 suggested that in 2005, $56.7 \mathrm{MtC}$ of $\mathrm{CO}_{2}$ emissions came from power stations and energy industries, representing just under 37 per cent of total $\mathrm{CO}_{2}$ emissions that year. Taxes on the production of energy may therefore represent a major way to reduce emissions. However, more recent interest has been paid to using the tax system to promote reductions in energy consumption by households and businesses, or to provide incentives for more efficient energy use. Clearly, energy production is driven by demand. Taxation of energy production will feed through into higher energy prices for end-users which should reduce demand, but recent debate has focused on the idea that taxing use directly might make the environmental consequences of energy use more explicit to the users. This section will consider both industrial/commercial taxation of energy and the current system of domestic taxation. Chapter 6 will consider the debate over the future of energy taxation in more depth.

Before looking at the system of taxes currently in place, it is worth looking at the trends in energy production over a relatively long time horizon and how these have affected emissions. It is not simply the total amount of energy produced that matters, but also the mix of fuel types used to produce it. As stated in Chapter 4, a large proportion of the reduction in $\mathrm{UK} \mathrm{CO}_{2}$ emissions can be traced back to the 'dash for gas' in the 1990s after the deregulation of the energy market. According to the March 2006 Energy Trends, producing 1 gigawatt hour (GWh) of electricity using coal produces 238 tonnes of $\mathrm{CO}_{2}$, compared with 207 tonnes from oil and 99 tonnes from gas. Nuclear and renewable generation is largely emissions-free.

Emissions from power stations fell by 16 per cent between 1990 and 2005, but closer inspection reveals this masks a decline of 29 per cent between 1990 and 1999 followed by a rise of 16 per cent between 1999 and 2005. This initial period corresponds to a time when coal use to generate electricity fell and gas use rose; since 1999, the amount of gas used has remained roughly stable but coal use has increased once more.

Figure 5.13 shows how the mix of electricity generation by fuel type has changed since 1990, based on calculating the equivalent oil use for each fuel type. The huge increase in the use of gas is evident from around 1993 onwards - gas accounted for just 2 per cent of production in 1992, but by 1999 this had risen to around one-third. The share from coal fell substantially, from just under two-thirds in 1990 to just over one-third in 2004. However, as already noted, the share from coal has risen since 1999 and the share from gas has stabilised. Generation from oil, accounting for around 10 per cent of total generation in the early 1990s, had declined to less than 2 per cent by 2004. The share from nuclear power peaked at just under 29 per cent towards the end of the 1990s and has since declined to around 21 per cent. Generation from renewable resources, accounting for less than 1 per cent of total generation in 1990, has since risen to 3.7 per cent. The largest single renewable source in 2004 was landfill gas, accounting for 42 per cent of the renewable production. Biofuels (including landfill gas) in total accounted for around 
Figure 5.13

Mix of electricity generation by fuel type

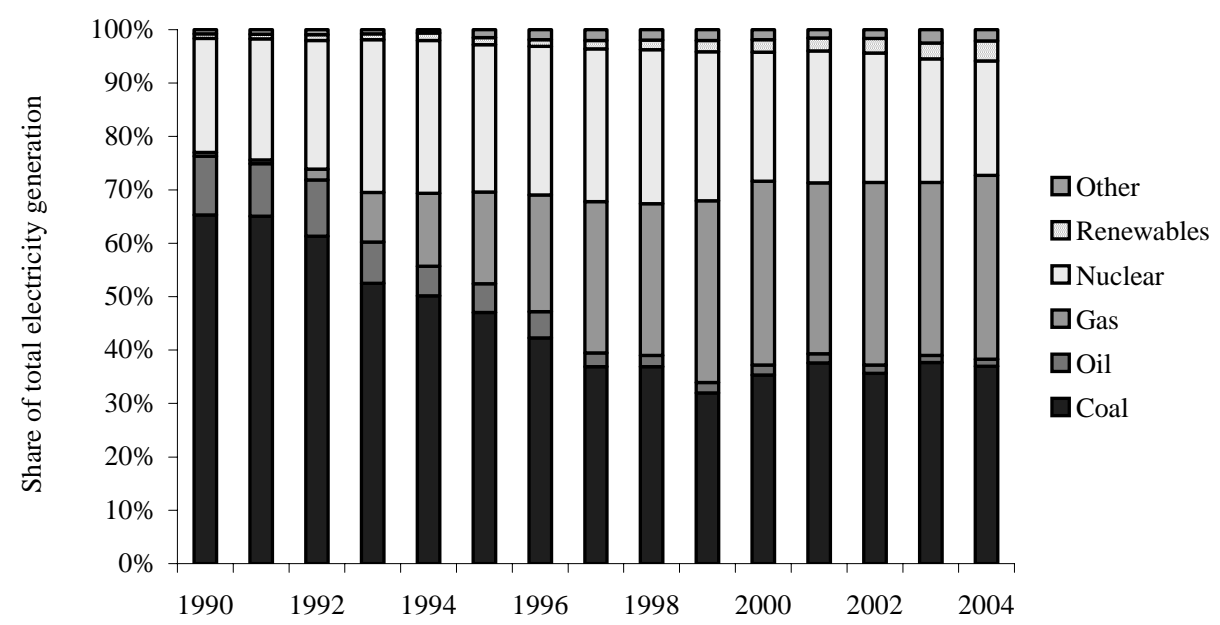

Note: Figures represent the share of each fuel type used in electricity generation by converting each to tonnes of oil equivalent.

Source: DTI, Energy Trends, March 2006 (http://www.dti.gov.uk/files/file27084.pdf).

81 per cent of total renewable electricity generation. Hydro-electric power accounted for 13 per cent and wind/wave power for 5 per cent. ${ }^{56}$

\subsubsection{VAT system}

The VAT system can have implications for environmental incentives for both households and businesses. VAT is the major indirect tax in the UK, raising in total an estimated £73.7 billion in 2005-06, ${ }^{57}$ third only to income tax and National Insurance contributions as a source of government revenue. By charging different rates of VAT for different products and services, the government can in principle affect the relative prices faced by consumers and so influence consumption decisions - for example, by reducing the rate of VAT for energy efficiency products installed in the home (see below for more). One difficulty with using the VAT system in this way rather than using explicit environmental taxes is that various European Union directives limit the ability of the government to impose different rates on different goods. In principle, all consumption should be subject to a VAT of between 5 and 25 per cent, though zero-rated items such as food and children's clothing remain in the UK. No additional items can be zero rated and rates above 25 per cent cannot be applied. This limits the scope to use the VAT system for environmental ends. Another problem with the VAT-based approach is that it complicates the administration of VAT for the authorities and for businesses.

\footnotetext{
${ }^{56}$ See http://www.dti.gov.uk/files/file17384.xls for a breakdown of renewable energy production since 1990.

57 HM Treasury, 2006b.
} 


\section{VAT on domestic fuel}

VAT is currently charged at three rates: 0 per cent for 'zero rate' items, 5 per cent for 'reduced rate' items and 17.5 per cent for 'standard rate' items. The standard rate of 17.5 per cent applies to transport fuel. VAT is also charged at the reduced rate of 5 per cent on domestic fuel - gas and electricity, for example - yet it is not included in the environmental tax receipt figures. In principle, however, by raising the price of fuel compared with a zero-rate tax, VAT can reduce consumption and therefore emissions.

VAT on domestic fuel was introduced in the 1993 Budget. Until then, it had been zero rated, which reduced the price of fuel relative to other goods and therefore distorted consumer demand towards fuel consumption. VAT was originally charged at 8 per cent from April 1994, with the intention of an increase to the full rate of 17.5 per cent in April 1995. However, there was significant opposition to this move, largely on the grounds of equity and concerns that poor and vulnerable households would suffer from higher energy bills. The rate was held at 8 per cent until September 1997, when it was reduced to 5 per cent as part of the first Budget of the Labour administration. Consumption of domestic fuel is therefore taxed relatively more lightly than most other consumption, despite the possible environmental gains to be had from a higher tax rate, though more heavily than was the case prior to 1994 .

It is not clear exactly how much of the total VAT revenue comes from the 5 per cent rate on domestic fuel, since receipts are not collected on a good-by-good basis. Some evidence can be gathered from the Treasury's annual Tax Ready Reckoner, which shows the estimated revenue effects of various tax changes. The latest figures from the 2005 document suggest that increasing the VAT rate by 12.5 percentage points to the standard rate would raise an additional $£ 2$ billion. This suggests that each percentage point of VAT on fuel raises around $£ 160$ million (assuming that there are no behavioural effects, i.e. households do not change their demand for fuel in the face of a higher price). This means that the 5 per cent rate currently raises approximately $£ 800$ million per year.

A key problem with using VAT on domestic fuel as a way to discourage use and reduce emissions is that it is applied at the same rate across all types of fuel, yet the environmental impact differs according to the type of fuel, the time, the location and so forth. A more direct way to target the environmental cost of domestic fuel use may be a so-called 'carbon tax', which would vary according to the carbon and energy content of fuels. Dresner and Ekins (2006), for example, suggest a domestic carbon tax equivalent to the climate change levy, a tax on the fuel use of the nondomestic sector (see Section 5.3.3). This would see a tax rate on electricity of $0.43 \mathrm{p} / \mathrm{kWh}$, more than twice the rate of tax on gas of $0.19 \mathrm{p} / \mathrm{kWh}$. We will consider the possibility of a carbon tax in more detail in Chapter 6.

The main social concern over VAT on domestic fuel is that it will exacerbate the problem of fuel poverty, a key policy target of government in recent years. Fuel poverty is defined as a situation where a household needs to spend more than 10 per cent of its income to heat its home adequately. Latest estimates for 2004 suggest that around 2 million UK households live in fuel poverty, of which around 1.5 million are defined as 'vulnerable' - that is, a household containing a child or an elderly, sick or disabled person (Department for Environment, Food and Rural Affairs and Department for Trade and Industry, 2006). Higher fuel bills, whilst 
possibly having a positive environmental effect, will therefore conflict with other government policy objectives - in particular, the goal of eliminating fuel poverty amongst vulnerable households by 2010. Various studies have suggested ways in which environmental targets could be met through fuel prices without increasing the rate of fuel poverty; we consider those arguments in the discussion of carbon taxes in the next chapter.

VAT on fuel is regressive. Figure 5.14 shows the estimated saving (as a percentage of total spending) made by households across the income distribution as a result of the rate of VAT on electricity and gas payments being reduced from 5 per cent to 0 per cent using data from the 2003-04 Expenditure and Food Survey. Households with the lowest 10 per cent of incomes would save, on average, 0.43 per cent of their budget, compared with 0.15 per cent for those households with the highest 10 per cent of incomes. However, it should be borne in mind that there is significant variation even within income groups for how much would be saved some households in the poorest income group would save almost 3 per cent of their total spending as a result of the abolition of VAT on fuel whilst others would save almost nothing. These figures also assume no behavioural response from the change, though earlier work at the time that VAT was first introduced on domestic fuel suggested that a VAT rate of 17.5 per cent would reduce energy consumption amongst the poorest fifth of households by around 9.2 per cent, compared with a reduction of just 1.1 per cent amongst the richest fifth of households (Crawford, Smith and Webb, 1993). ${ }^{58}$ This implies that incorporating a behavioural response

\section{Figure 5.14}

Estimated reduction in cost of living from abolition of the 5 per cent VAT rate on domestic fuel (gas and electricity), by income decile, 2003-04

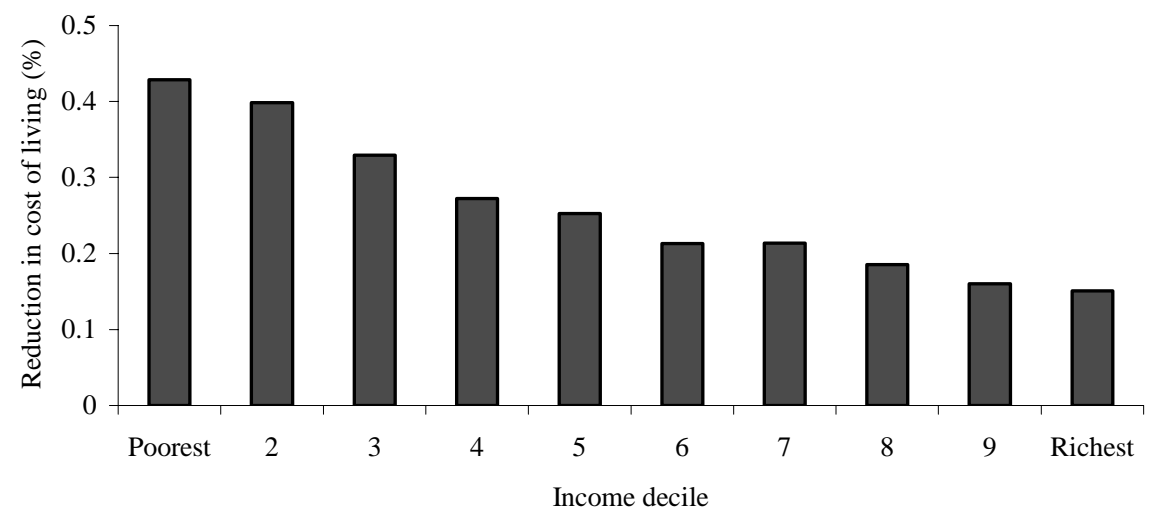

Notes: Figures exclude households that reported expenditure of less than $£ 1$ per week on electricity and gas. Income and expenditure were equivalised using the OECD equivalence scale.

Source: Author's calculation from 2003-04 Expenditure and Food Survey data.

\footnotetext{
58 These figures also suggest that fuel expenditure is inelastic - the reduction in demand is less than the increase in price. This is to be expected given that fuel is a necessity. Studies cited by Dresner and Ekins (2006) on the effects of carbon taxes in Scandinavia have also suggested that the overall effects on demand are quite low.
} 
would enlarge the gains made by the poorest group, though on average the effects would likely still be small since the tax change is just 5 percentage points rather than 17.5 percentage points.

\section{Other incentives in the VAT system}

In recent years, other small changes have been made to the VAT system which appear to offer environmental incentives. The reduced rate of 5 per cent is payable for the installation of many energy-saving materials (ESMs) in homes, a change that was introduced in 1998 in limited circumstances and subsequently extended. ${ }^{59}$ Eligible ESMs include draught stripping around windows and doors, insulation, solar panels, wind/water turbines, air source heat pumps and micro combined heat and power units. Prior to the change, the full rate of 17.5 per cent was applicable, so the reduced rate represents an effective price reduction for the installation of these materials. HM Treasury (2005) estimates that the change cost around $£ 50$ million per year in lost revenue.

In 2001, the VAT rate for property conversion was reduced from 17.5 per cent to 5 per cent. The reduced rate applies to the renovation of homes that have been empty for at least three years, and for the conversion of residential property into multi-occupancy dwellings (i.e. the conversion of a house into flats). ${ }^{60}$ This substantially reduced, but did not eliminate, the gap between VAT on the construction of new homes, which is zero-rated, and that on renovation and conversion. The latter is likely to have a lower environmental cost (particularly in terms of the use of greenfield land). HM Treasury (2005) estimates that the reduction led to a loss of revenue of around $£ 150$ million per year.

\subsubsection{Domestic incentives}

Aside from VAT-based incentives, there are various other measures in place to provide domestic energy users with incentives to install energy-saving materials in the home. Why should the government intervene to promote energy efficiency directly, rather than simply introducing an energy tax which would then provide incentives for households to invest in energy efficiency themselves? Brechling and Smith (1994) argue that there are additional market failures in the energy efficiency market which might prevent households from efficiently investing in energy efficiency measures without direct intervention. One example is credit market failures, where poorer households may be unable to afford investments and be unable to borrow money to spend on energy efficiency improvements despite the future savings these would generate. To the extent that such failures are related to incomes, they would tend to exacerbate the negative distributional implications of any move towards a direct energy tax on the household sector. Other failures may be more related to housing tenure: renting households would have to rely on their landlords to install efficiency measures but, since landlords are typically not

\footnotetext{
${ }^{59}$ Full details are available from the HMRC VAT Notice 708/6 Energy-Saving Materials (http://customs.hmrc.gov.uk/channelsPortalWebApp/channelsPortalWebApp.portal? nfpb=true\& pageLabel =pageVAT ShowContent\&propertyType=document\&id=HMCE CL 000514).

${ }^{60}$ Full details are available from the HMRC Budget 2002 Notice VAT: Reduced Rate for Residential Conversions and Renovations

(http://customs.hmrc.gov.uk/channelsPortalWebApp/downloadFile?contentID=HMCE CL 000775).
} 
responsible for paying the energy bills, there is little incentive for them to do so. ${ }^{61}$ Thus schemes such as those described below have justifiable economic rationale.

\section{Warm Front}

The Warm Front scheme ${ }^{62}$ provides up to $£ 2,700$ worth of energy efficiency measures (cavity-wall insulation, loft insulation, central heating, low-energy light bulbs and so on) for low-income households in receipt of certain state benefits. The scheme began in 2000. The main aim of Warm Front is to reduce fuel poverty amongst vulnerable households, but it also has an environmental impact by reducing domestic energy use. DEFRA, which funds the scheme, estimates that just over 200,000 households received some grant in 2004-05 at a cost of around $£ 150$ million. ${ }^{63}$ Eaga Ltd, one of the partners that administer the scheme on behalf of DEFRA, gave grants to around 137,000 households in 2003-04. It also breaks down numbers according to the household's SAP (Standard Assessment Procedure) band before the grant was given. The SAP score ranges from 0 to 120 , with a higher value indicating a more energy-efficient household. According to Eaga, 11,000 households in the $0-10$ band received a grant in 2003-04, increasing their rating from an average of 6.2 to an average of 54.1, which Eaga estimated would save them around $£ 1,000$ per year in energy bills. ${ }^{64}$ Powergen Ltd, another partner, estimated that the average reduction in $\mathrm{CO}_{2}$ emissions from each of the 68,000 or so households receiving grants under its administration in 2004-05 was around 0.8 tonnes per year (from 6 to 5.2). ${ }^{65}$ However, a report by the National Audit Office (2003) suggested that whilst Warm Front did give grants to more very-low-energyefficient households than the national average, it gave proportionately few grants to households with below-average efficiency. In addition, the NAO argued that around 20 per cent of grants provided no significant impact on the household's SAP rating. This is because eligibility is not based on the energy efficiency rating of the household, but rather on receipt of state benefits and the presence of vulnerable people in the household. Targeting the scheme at low-income households in energyinefficient properties would probably increase the environmental impact.

\section{Landlord's Energy Saving Allowance}

Another incentive in the tax system is the Landlord's Energy Saving Allowance (LESA), introduced in 2004. It allows landlords who install cavity-wall, solid-wall or loft insulation, draught proofing or hot-water-system insulation in houses that they let out to claim a deduction of up to $£ 1,500$ per building against income tax. This again in principle provides a financial incentive to invest in energy efficiency for landlords, the incentives would be dulled if the benefits of lower energy bills did not accrue to them directly (i.e. if the utility bills are paid by tenants). This is a small measure, with the estimated cost to the Treasury given in Budget 2006 as only

\footnotetext{
${ }^{61}$ Landlords could charge higher rents if they installed energy efficiency measures, but unless tenants were able to observe the energy efficiency of the property accurately, they may not be prepared to pay a higher rent. Equally, rent controls may apply in some cases, limiting this flexibility.

${ }^{6}$ See http://www.defra.gov.uk/environment/energy/hees/index.htm for information.

63 DEFRA website at http://www.defra.gov.uk/environment/energy/hees/04.htm and National Audit Office (2003).

64 See Eaga Ltd (2004) for details.

65 See Powergen Ltd (2005).
} 
$£ 10$ million for 2006-07. No information on the number of measures installed as a result is available. The LESA is due to expire in 2009.

\section{Incentives in local taxation}

Rebates on local taxation offer a further potential source of incentives to households to engage in energy-efficient measures. There has been much discussion about the prospect of using the council tax to provide incentives for installing insulation, recycling and so on, and Chapter 6 discusses some of the ideas in more depth.

In 2006, DEFRA announced that it was extending a scheme, in partnership with British Gas, to offer households in 16 local authorities up to $£ 100$ in council tax rebates if they installed subsidised cavity-wall insulation. ${ }^{66}$ DEFRA argued this would provide households with a saving of up to $£ 485$ over five years based on the estimated fuel bill savings. DEFRA estimated the total emissions reduction could be 193,000 tonnes of carbon (based on cavity-wall insulation, saving a typical threebedroom household 0.22 tonnes of carbon per year) if all eligible households took up the scheme.

\subsubsection{Climate change levy}

\section{Background and design}

The climate change levy (CCL) is a tax on the supply of energy to business. It was announced as a measure in the 1999 Budget and implemented in April 2001, giving businesses time to adjust before the tax came into force.

The background to the CCL was a report by Lord Marshall in 1998 which examined ways to use economic instruments to reduce industrial and commercial emissions of greenhouse gases. The report argued that there was scope for a welldesigned tax since a system of permits alone would be unlikely to cover many small and medium-sized enterprises (SMEs). Many of the features of the tax suggested by Lord Marshall are evident in the design of the CCL. For example, it is a tax on the supply rather than the use of energy since this makes it easier to distinguish whether the user is domestic or business. The report also suggested that the revenues ought to be recycled to the business sector so as to minimise the effect on competitiveness; at the time the CCL was brought in, employers' National Insurance contributions were reduced by 0.3 percentage points to compensate firms and shift the tax burden onto energy and away from labour costs. By raising the price of energy, the CCL should provide incentives for energy efficiency, reduced consumption and switching to low-emissions fuels that do not attract a tax.

The CCL is charged at different rates according to the type of fuel supplied and its energy content. Electricity attracts the highest tax rate since the losses through generation, transmission and distribution are high. Gas, coal and LPG attract lower rates. Electricity generated from renewables, waste solids and combined heat and power stations is exempt to encourage switching of supplies. In addition, natural gas supplied in Northern Ireland is exempt (the Treasury argues that this is because the market is very small and less polluting than alternatives such as coal and oil). This exemption is currently set to expire in April 2011.

\footnotetext{
${ }^{66}$ See http://www.defra.gov.uk/news/2006/060313a.htm for full details.
} 
Table 5.10

Rates of climate change levy, 2001-07

\begin{tabular}{l|rrrr}
\hline & Electricity & Natural gas & LPG & Solid fuels \\
\hline April 2001 & $0.43 \mathrm{p} / \mathrm{kWh}$ & $0.15 \mathrm{p} / \mathrm{kWh}$ & $0.96 \mathrm{p} / \mathrm{kg}$ & $1.17 \mathrm{p} / \mathrm{kg}$ \\
& & & $(0.07 \mathrm{p} / \mathrm{kWh})$ & $(0.15 \mathrm{p} / \mathrm{kWh})$ \\
April 2007 & $0.441 \mathrm{p} / \mathrm{kWh}$ & $0.154 \mathrm{p} / \mathrm{kWh}$ & $0.985 \mathrm{p} / \mathrm{kg}$ & $1.201 \mathrm{p} / \mathrm{kg}$ \\
\hline
\end{tabular}

The CCL is a 'downstream' tax - this means that the charge is on the energy users, not the generators. Thus there is no direct incentive on generators to change to low-emissions sources of energy such as renewables (though there may be indirect incentives to the extent that demand for such energy increases). However, an upstream tax levied on generators would have made an exemption for the household sector harder to administer (though, of course, the household sector is still likely to bear some of the ultimate incidence). A full discussion of some of the political economy issues surrounding the introduction of the CCL can be found in Pearce (2005).

Table 5.10 shows the rate of the CCL for different fuels. These rates have remained unchanged since the introduction of the levy in 2001, meaning that the April 2006 values are around 13 per cent lower in real terms than the introductory rates. Budget 2006 signalled an increase in the CCL by inflation from April 2007.

At the time the CCL was introduced, the government also implemented a scheme of Climate Change Agreements (CCAs) which provided energy-intensive sectors with a chance to reduce their CCL tax bills by 80 per cent in exchange for entering into agreements to meet energy efficiency targets. The trade associations for firms in these sectors negotiate with DEFRA to create the CCAs on behalf of the firms they represent. These 'umbrella agreements' detail targets for energy use, for example. The DEFRA website currently lists 43 umbrella agreements for industry sectors ranging from egg production to printing to brewing. ${ }^{67}$ Industries with CCAs can also participate in the UK Emissions Trading Scheme to help meet their targets.

Also in 2001, the government introduced a 100 per cent first-year offset against profits for corporation tax for investments made in energy-saving technologies by firms. This system, known as the 'enhanced capital allowance', is similar to the idea of using incentives in local tax to encourage domestic investment in energy-saving technology. The full list of qualifying investments can be found on the HMRC website and currently includes combined heat and power (CHP) systems, boilers, heat pumps and so on. ${ }^{68}$

It is important to note that the CCL is a tax on energy supply to business and not directly on carbon content of fuel. In 1999, the Royal Commission on Environmental Pollution, an independent body, sent a letter to the Chancellor stating its concern that the CCL was therefore a blunt instrument to tackle carbon emissions $^{69}$ - though clearly reducing energy demand (or promoting energy efficiency) would have an effect on emissions, it may not be so high as if the tax were levied directly on the emissions content of different fuels. The government

\footnotetext{
${ }^{67}$ See http://www.defra.gov.uk/environment/ccl/agreements. htm for the full list.

${ }^{68}$ See http://www.hmrc.gov.uk/capital allowances/eca-guidance-pt1.htm for the full list.

${ }^{69}$ See http://www.rcep.org.uk/news/99-2.htm for full text of the letter.
} 
argued that identifying the carbon content of different fuels was complicated, so an indirect levy on energy use was simpler to implement, though estimates of at least the average carbon content of various types of fuel do exist which could have formed the basis of the tax rate. Of course, changes to the CCL, such as providing exemptions for fuel generated from renewables, have given it more of the features one would find in a tax on carbon content.

\section{Revenue}

Figure 5.15 shows real-terms revenue from the CCL between 2001-02 and 200506. It is clear that revenues peaked in the first full year of operation, at just under $£ 900$ million. Since then, real-terms revenues have declined, largely as the rates have remained frozen whilst business energy use has become more efficient. By 2005-06, real revenues were around 16 per cent below their peak. The government forecast revenue for 2006-07 at £700 million in the 2006 Budget.

In the 1999 Budget, when the CCL was announced, the forecast was for revenues of around $£ 1.75$ billion in the first full year of operation, 2002-03. The actual revenue was only around half this level, but close to the projected revenues of $£ 1$ billion that were made in the Pre-Budget Report in November 1999. The difference seems to be that during that period, the scope and rates of the CCL were changed after a further consultation period.

Around three-quarters of total revenue comes from the supply of electricity and a quarter from the supply of natural gas; solid and other fuels generate very small revenues each year. It does seem that some switching from electricity to gas has taken place since the start of the CCL, however - real-terms receipts from gas supplies have remained roughly constant at about $£ 200$ million per year whilst receipts from electricity supply have fallen from about $£ 640$ million to £530 million.

Figure 5.15

Revenue from climate change levy

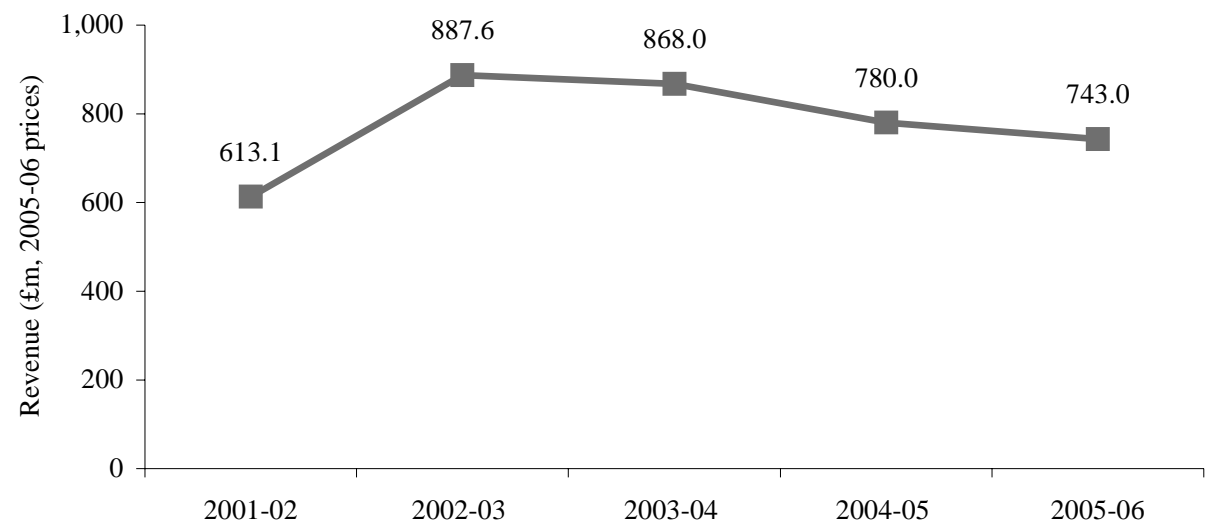

Notes: Figure for 2001-02 is part-year. Figure for 2005-06 is projected. Revenues are deflated to 2005-06 values using the GDP deflator.

Source: HM Revenue and Customs, 2006d. 


\section{Effectiveness}

Figure 5.16 shows trends in energy use in the service and industrial sectors between 1970 and 2004. However, simply looking at total business use of energy before and after the introduction of the tax will not be enough to discern its effects, since the key question is what would have happened in the absence of the CCL. Business use of energy depends on demand, energy prices, energy efficiency and so on. If the period just prior to the charge was characterised by high economic demand and the period just after the charge by low economic demand, then there may be a drop in energy use (and thus emissions) that could be attributed to the tax but in fact would owe more to business activity. The decline in industrial emissions and the rise in service emissions relate strongly to the switch in UK economic output from secondary to tertiary industries. Figures from the DTI show that between 1978 and 2004, employment in industry fell from 7.1 million to 3.3 million. At the same time, industrial output rose by around 30 per cent and energy intensity (energy used per unit of output) fell by more than 50 per cent. Over the same period, employment in the service sector rose from 16.4 million to 24.1 million, total output almost doubled and energy intensity fell by almost half. Knowing the contribution made by the CCL to these trends after 2001 (for example, the drop in energy use between 2001 and 2002) is crucial in evaluating its effectiveness.

In 2005, a report commissioned from Cambridge Econometrics and the Policy Studies Institute by the (then) Customs and Excise attempted to evaluate the initial impact of the CCL on its environmental objectives precisely by constructing an alternative scenario for what would have happened in the absence of the levy. ${ }^{70}$

Figure 5.16

Total energy use in the service and industrial sectors

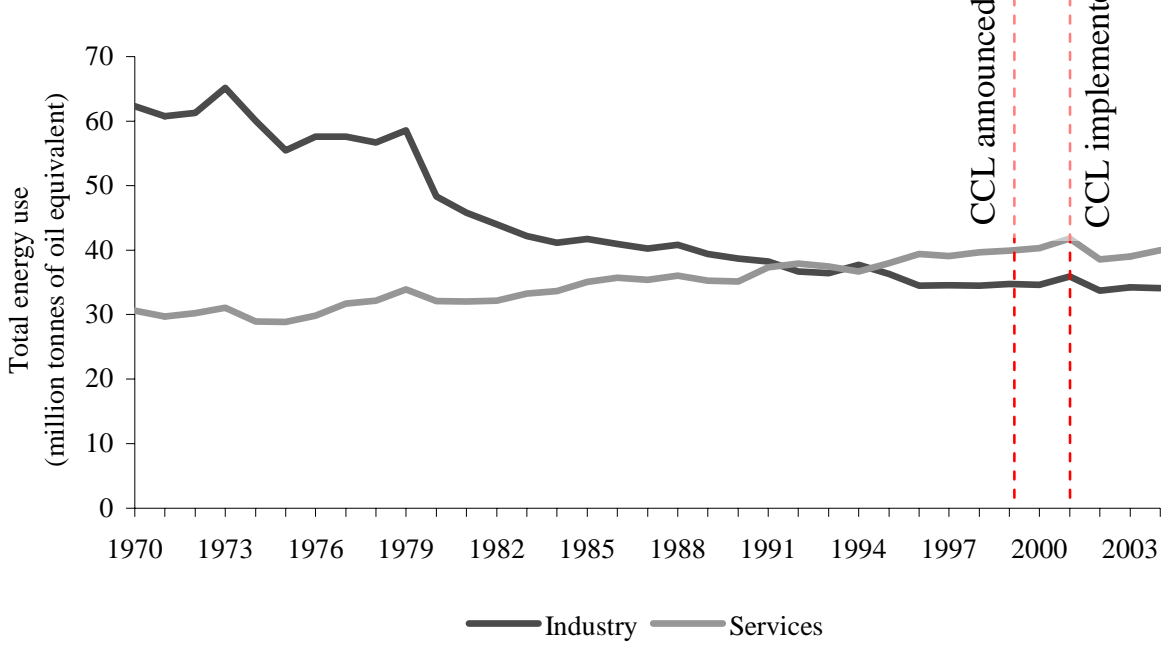

Note: Industrial figures between 1995 and 1996 are not totally comparable as the later figures exclude energy used in transformation activities.

Source: ONS/DTI Energy Statistics, http://www.dti.gov.uk/energy/statistics/index.html.

${ }^{70}$ For a summary of the report, see HM Treasury (2006a). 
Using a model of the economy and data on energy use and intensity (i.e. the energy consumed to produce each unit of output) across different sectors, the report assessed the 'announcement' effect of the tax (how business changed its behaviour in anticipation of the levy being introduced from its announcement in Budget 1999), the effects of the tax on business energy use and emissions up to the first quarter of 2004, other economic effects and projected effects until 2010.

The report found that simply the announcement of the CCL in 1999 reduced energy demand amongst non-industrial businesses by around 1.2 per cent in 2000, and by 0.2 per cent in the economy overall. It suggested that by 2010, the CCL will have led to an overall reduction in energy demand of 2.9 per cent, though this and all other findings were based on the assumption that the rates of the CCL would rise in line with inflation between 2005 and 2010. As we have seen, the CCL remained frozen in both 2005 and 2006, so it is likely that these estimates, as well as those for carbon emissions reduction, are slightly too high.

In terms of emissions, the report found that by 2010 the CCL would help reduce emissions of $\mathrm{CO}_{2}$ by around $3.7 \mathrm{MtC}$ per year and that there would be a cumulative reduction of around $16.5 \mathrm{MtC}$ by 2005. The reduction of $3.7 \mathrm{MtC}$ represents around 2.3 per cent of estimated total $\mathrm{CO}_{2}$ emissions in 2010.

More than half of these savings are estimated to come from non-industrial businesses since many industries are able to negotiate Climate Change Agreements and so reduce their liability to the CCL by 80 per cent. Another large source of savings is the reduced emissions from power generation through reduced demand for energy, which represents about one-fifth of the estimated reduction in emissions in 2010 .

The report also looked at the impact of the CCAs, since they provide clear incentives to reduce energy use and emissions in return for a lower tax bill. HM Treasury (2006a) notes that

CCAs were originally forecast to save $2.5 \mathrm{MtC}$ per year by 2010 . In fact ... sectors exceeded their interim targets by a significant amount - an extra $1 \mathrm{MtC}$ in the first target period to 2002, and an extra $1.4 \mathrm{MtC}$ in the second target period to $2004 \ldots .$. It is [now] estimated that the climate change agreements will, in aggregate, save around $2.8 \mathrm{MtC}$ a year by 2010 .

The Cambridge Econometrics and PSI study (2005) also noted that firms with CCAs also seemed to be over-hitting their targets, and argued that

Only for one sector (other industry in 2008) did we find that the CCA target would have been missed had no CCL ever existed. We also found that the price effect of the reduced-rate CCL was sufficient, on its own, for the target to be met.

This seems to imply that the CCA targets were too lenient - firms would have achieved their targets in any case and as such were enjoying a reduced-rate CCL for effectively doing what they would have done. However, Ekins and Etheridge (2006) suggest that the CCA targets encouraged firms to reduce energy use further than they would have done without them by providing an 'awareness effect' to industry similar to the 'announcement effect' of the CCL that the Cambridge Econometrics / PSI study found for the non-industrial sector. In other words, although firms with 
CCAs would likely have hit their CCA targets in any case, they may not have reduced demand and emissions by quite so much without them.

\section{The future of the CCL}

The CCL has now been in place for five years, and it seems that it will remain in place for the rest of the current Parliament. The most likely policy change will be continued uprating in line with inflation beyond 2007-08, possible changes to the exemptions available for fuels from renewables, changes to the targets for CCAs and changes to the list of investments eligible for enhanced capital allowances. However, the longer-term future of the CCL is dependent on the political situation after the next General Election (expected in 2009 or 2010). The Conservatives have pledged to abolish the CCL should they take power and replace it with a market mechanism (either a tax or a system of permits) that would relate directly to the carbon content of different fuels. Another possibility is that a carbon tax could be introduced that applied not only to firms but also to the domestic sector. We consider that possibility in the next chapter. 


\section{CHAPTER 6 The Future of Environmental Taxation?}

This chapter looks ahead at three new measures that may be introduced in the future. It is not designed to be an exhaustive list of possibilities and does not represent things that are certain to be enacted. Rather, it examines some possible reforms that have been suggested by academics or politicians, looking at evidence on their possible impact from an economic perspective, how the measures may interact with the rest of the tax system and government policy, and any evidence on the distributional implications where they seem important. Evidence from other countries will be considered where appropriate.

\subsection{Road user charging}

Section 5.1 highlighted that the external costs of motoring are varied and complex and are not constant across time, space or vehicle type. The current system of VED and fuel duty provides relatively blunt instruments to internalise the externalities and does not provide optimum incentives for motorists. Some will pay too much and others too little relative to the external costs they create. As such, there is serious academic and policy interest in the possibility of introducing a national scheme of road pricing, where the tax paid would vary according to a variety of factors, including (possibly) the environmental impact.

The Department for Transport (2006b) commissioned a survey of public attitudes towards road pricing, suggesting the current policy interest. Until recently, the government had seemed set to introduce a system of road pricing for lorries in 2008, called the lorry road user charge (LRUC). In Summer 2005, it was announced that the planned LRUC had been abandoned. However, in making this statement, the then Secretary of State Alistair Darling announced that 'We are now taking forward work on a national system of road pricing, so it is right for us to take forward the plans for distance-based lorry charging as part of the wider work on national road pricing - to work for a single, comprehensive, cost-effective system'. No timescale was announced, and there would be many complexities to introducing a national system so it is unlikely to be implemented for many years. In the interim, the idea of charging for access to certain roads at certain times is gaining increased currency, with developments such as the London Congestion Charge (introduced in 2003) and motorway tolls such as the M6 toll road.

Typically, a road user charge would work by charging motorists per mile or kilometre driven according to where and when they drove. Driving in the centre of a city at 9am would attract a higher charge than driving down a rural road at 5am because the costs of doing so in terms of congestion, accidents, road damage and emissions are greater. In principle, the charge can therefore reflect all the externalities of motoring and as such provide the correct price incentives to drivers. Cars would be fitted with some kind of device to monitor the time, their location 
and distance travelled; the charge might then be automatically deducted from a preloaded credit or billed to motorists.

Environmental objectives could be factored into a scheme such as this either by trying to estimate the environmental costs incurred from driving in particular locations at particular times or by allowing the charge to vary according to the emissions rating of the vehicle, thus incorporating the key feature of graduated vehicle excise duty. However, a system of road pricing that was able to distribute traffic better and therefore increase traffic flows and average speeds may have the consequence of increasing emissions rather than reducing them. Work by the Social Market Foundation (2006a) suggests that emissions fall as vehicle speeds rise from 0 to $10 \mathrm{kph}$, stabilise and then rise as speeds increase above $45 \mathrm{kph}$. Thus the effectiveness of the London Congestion Charge in reducing emissions (Transport for London (2005) argued that the charge reduced $\mathrm{CO}_{2}$ emissions in the charge zone during chargeable hours by 20 per cent and total fossil fuel use by 19 per cent) was largely due to a reduction in the time spent queuing and idling at junctions. However, if a road pricing scheme were able to increase speeds on motorways and dual carriageways, emissions could rise in some areas.

Another key effect of a road pricing scheme on emissions would be felt according to how it interacted with the existing tax system. If VED and petrol taxes were abolished or dramatically cut so as to make the overall effect revenue-neutral, then for many drivers the tax they paid on private motoring would fall (typically, such a policy would represent a net transfer from urban drivers to rural drivers and all non-drivers since the charges would be much higher in urban areas where congestion costs are greater). Glaister and Graham (2006) analyse how a revenueneutral road pricing scheme based on environmental and congestion costs and a revenue-additional scheme (i.e. introduced on top of existing policy with no compensating reduction in fuel duties) would affect traffic levels and speeds at a ward-by-ward level. They find that whilst there would be a cut in traffic volumes (and emissions) in all wards if the scheme were revenue-additional, if it were revenue-neutral there would be an increase in traffic volumes of up to a quarter across much of Scotland, Wales, East Anglia and the South West, and reductions in volume of up to one-third in London and other urban centres. The Social Market Foundation (2006b) wonders whether 'a decrease in congestion at the expense of increased traffic and possibly emissions ... [and] an increase in the cost of motoring for the majority at the expense of a decrease in the cost of motoring for a minority [are] politically acceptable outcomes of a national road-user charging scheme'.

Thus whilst road pricing remains a distinct possibility for the future, there are many issues, particularly in terms of technology, design and implementation, equity and concerns over monitoring vehicle location that need to be considered before a national scheme is likely. In terms of its environmental effect, the way in which environmental incentives are incorporated into the scheme and how it affects existing motoring taxes would be critical. A key argument in favour of retaining at least some fuel duty is that it provides incentives to drivers and manufacturers to favour fuel-efficient vehicles which a purely distance-based system of taxation would not. 


\subsection{Carbon tax}

Section 5.3 discussed current taxes on energy, and it is clear that at the moment the focus of efforts to reduce energy-related emissions is on business and industrial use, via the climate change levy, rather than on domestic use. In April 2006, the Conservative leader, David Cameron, called for the CCL to be replaced with a tax based directly on the carbon content of fuels used by business, and Liberal Democrat policy is also to tax carbon use by business rather than energy use. Whilst reforms to the CCL have moved it towards having the characteristics of a 'carbon tax' (such as exemptions for fuel produced from renewables), some, such as the Royal Commission on Environmental Pollution cited in Section 5.3, have called for the tax to be applied to domestic energy use as well as industrial use. Clearly, such a tax would provide incentives to switch to low-carbon fuel sources and to reduce overall energy consumption by raising the price relative to other goods and increasing awareness of the environmental effect of the domestic use of energy.

The current government has ruled out a tax on domestic energy use ${ }^{71}$ (having already reduced the VAT rate on it from 8 per cent to 5 per cent), but the debate around using a carbon tax or other domestic energy tax has been gathering pace recently. Figure 4.3 demonstrated that whilst emissions from industrial and commercial sources have declined markedly since 1990, those from residential sources have remained roughly constant. Recent forecasts by Cambridge Econometrics (2006) imply a growth in emissions from households of 9.25 per cent between 1990 and 2010.

Smith (1995, pp. 77-80) discusses a proposal by the (then) European Community to introduce an EC-wide carbon tax in the mid-1990s. Though that proposal was never implemented, a number of current EU countries do have domestic carbon or energy taxes. Dresner and Ekins (2006) provide a summary, citing a study of the Swedish carbon tax which suggested that $\mathrm{CO}_{2}$ emissions were 7 per cent lower overall than would have been the case without it (Swedish Environmental Protection Agency, 1995) and a study of the Danish energy tax which claimed a reduction of 10 per cent in energy use as a result (Bjorner and Jensen, 2002).

Whilst international evidence therefore suggests that a domestic tax on carbon emissions would go some considerable way to changing consumer behaviour, the key concern that has led the government to rule out such a policy is the effect on low-income households and how it would affect the fuel poverty targets discussed in Section 5.3. Dresner and Ekins (2006) use data from the UK Family Expenditure Survey and the 1996 English House Condition Survey to simulate the effect of introducing a domestic energy tax at the same rate as the climate change levy, roughly equivalent to $£ 10$ per tonne of $\mathrm{CO}_{2}$. They estimate that such a tax could raise around $£ 1.3$ billion per year, or $£ 1$ per week from each household. Around 90 per cent of households would pay more than 10p a week and 6 per cent of all households more than £2 a week. Figure 6.1 shows how Dresner and Ekins estimate the impact would be felt across the income distribution: on average, households lose around £50 per year or 0.22 per cent of total income. Households in the poorest

${ }^{71}$ See, for example, page 27 of HM Treasury (2002). 
Figure 6.1

Estimated income losses from putative household carbon tax

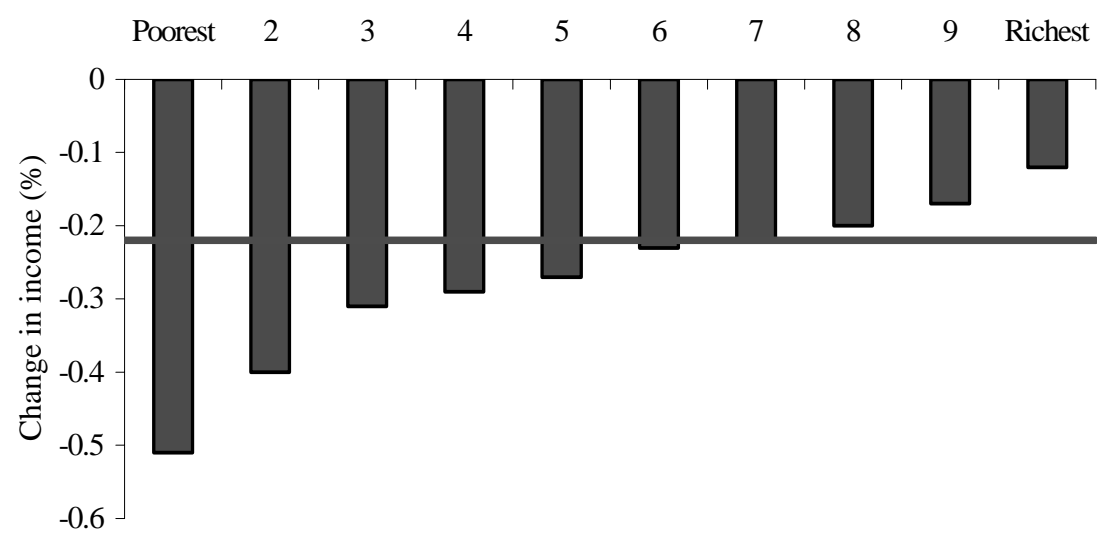

Note: Horizontal line shows average income loss across whole population of 0.22 per cent. Tax is set at same rate as CCL.

Source: Dresner and Ekins, 2006.

tenth of the population would lose around 0.5 per cent of income (around $£ 37$ per year) whilst those in the richest tenth would lose around 0.1 per cent of income (around £67 per year). Not surprisingly, therefore, a domestic carbon or energy tax would be regressive, costing poorer households proportionately more than richer households and possibly increasing rates of fuel poverty.

However, this kind of tax need not be introduced in isolation - Dresner and Ekins go on to discuss a variety of ways in which other domestic taxes could be adjusted to compensate households, particularly low-income households, for the loss of income (a similar discussion can be found in Smith (1992)). They conclude that measures such as increasing pensioners' winter fuel allowance, higher income support and working and child tax credits, and increased housing or council tax benefit could actually make a carbon tax progressive whilst still reducing carbon emissions and leading to no net effect on tax revenues. However, one key problem is that there is enormous variation in energy consumption within income groups. Some low-income households consume very little energy and others a great deal. This may be related to the problems surrounding energy efficiency investments (due to tenure or credit market failures, for example) discussed in Section 5.3.

Dresner and Ekins (2006) argue that at least 20 per cent of the poorest group those most likely to be in fuel poverty - will still be negatively affected irrespective of the compensation scheme used and conclude that

although redistributing the revenues from a carbon tax through means-tested benefits would certainly be progressive overall ... it does not seem to be possible to devise a means of doing it that would not also worsen fuel poverty for those who are already most badly affected by it. This makes it politically problematic at best, and probably politically infeasible. 
If a carbon tax on domestic energy is unlikely, at least in the foreseeable future, then there may be other ways to incentivise households to reduce emissions. A report by Dresner, Ekins and Willis (2006) at the Policy Studies Institute for the Green Alliance called for a 'green living initiative' to include taxes on high-energyuse products such as standard light bulbs, disposable batteries and disposable cameras. It also called for incentives to be incorporated into the council tax system that would offer rebates for households that install energy-saving measures such as insulation. Similar ideas are developed by Dresner and Ekins (2006), who suggest surcharges on council tax and stamp duty for households that do not carry out energy-saving investments in the home. They argue that such incentives would make it easier to identify households where energy-saving measures are not costeffective to implement. Such households may be particularly at risk of fuel poverty and would be most likely to lose heavily from any carbon tax, but if they are identifiable after a period of time during which incentives for energy-efficient investments have been in place, it may make it easier to compensate such households if a carbon tax were introduced later.

\subsection{Taxes on plastic bags}

A proposal that has been considered in recent years is a tax payable on single-use plastic bags from supermarkets and other retailers, largely in response to a similar levy introduced in the Republic of Ireland in 2002. Estimates from DEFRA suggest that around 8-10 billion plastic bags are used in the UK each year. The environmental impact of plastic-bag use comes through litter, waste and landfill costs, damage to wildlife that eat discarded bags and use of natural resources in their manufacture. These costs are external costs and as such there may be a case for charging a levy on the bags (notionally on the firms that supply them, though in practice the charge would be passed on to consumers), which are typically given away free at the moment. ${ }^{72}$

In 2005, a Bill was presented to the Scottish Parliament which would charge a levy of 10p on plastic bags provided to customers in Scotland, with revenues ringfenced for environmental programmes. The proposal is currently under consideration, with an initial report published in $2005 .{ }^{73}$ Part of the report looked at a commissioned study by AEA Technology to assess the likely impact of a Scottish bag tax; it concluded that whilst there may be some environmental benefits from an estimated 90 per cent reduction in the use of plastic bags, there would also be costs as consumers would switch from plastic to paper bags, which are typically less

\footnotetext{
72 In 2006, IKEA stores in the UK began charging $5 p$ for each plastic bag and reduced the price of reusable 'bags for life'. In a press release, the store argued that this would reduce consumption by 20 million bags per year by 2007 (from 32 million in 2005). Note that the same press release also suggested a figure for total plastic bag use in the UK of 17.5 billion per year, though the statistic is not sourced. The press release is available at

http://www.ikea.com/ms/en GB/about ikea/press room/press release/national/plastic bag campaign.html. B\&Q stores began a trial of charging $5 p$ per bag in Scotland in 2004, which reduced demand by 85 per cent (see, for example, http://www.scotland.gov.uk/Publications/2005/08/1993259/33025), and LIDL stores throughout the UK charge $5 p$ per bag.

${ }^{73}$ See Scottish Parliament Environment and Rural Development Committee (2005). A summary is available in Lamb (2005).
} 
likely to be reused. The report argued that greater environmental benefits would be felt in extending the charge to paper as well as plastic bags, though Friends of the Earth argued that the report underestimated substitution towards reusable canvas bags. The report also estimated net annual revenue of around $£ 4$ million, which could have positive environmental impacts depending on how it was used, though overall the environmental benefit was 'at best, ..., deemed to be moderate in the overall context'. Any possible distributional concerns were deemed to be very small.

Perhaps one reason why a plastic bag tax has been championed is that the Irish experience has suggested the effect on consumer behaviour from even a moderately low tax could be quite dramatic and that popular support for the tax in Ireland has remained high. Lamb and Thompson (2005) discuss evidence on the Irish tax, which was introduced in 2002 at $€ 0.15$ per bag. Revenues are diverted to an Environment Fund used to pay for waste management and anti-littering projects. Typical estimates are that the levy reduced annual use of plastic bags by around 9394 per cent, from around 1.26 billion to 76 million. There appeared to be some switch to paper bags (particularly in the non-food sector) and some unintended consequences (such as consumers stealing baskets and trolleys to transport purchases without buying a bag).

Although the government has no plans for a tax in England and Wales, it is likely to remain a possibility, particularly if the Scottish tax is implemented. The environmental benefits may be small and any revenues are likely to be marginal, but it would be a visible charge that might be part of a package of measures designed to raise consumer awareness about the environmental consequences of their behaviour. The tax may also be extended to paper bags or packaging more generally (encouraging manufacturers to reduce the amount of packaging on food and other products). 


\section{CHAPTER 7 Conclusion}

Environmental concerns on both sides of the Atlantic have probably not been so high on the political agenda since the time of the Kyoto Protocol ratification. Interest in how the tax system can best be used to provide environmental incentives for businesses and domestic consumers is high and the academic debate on global warming, climate change and policy has intensified. Despite this, in most countries, environmental taxes are contributing a smaller share of tax revenue and represent a lower proportion of national income than was the case a decade ago. In the UK, this is largely due to the change in policy concerning fuel duty in 1999. However, although overall revenues in real terms may be slightly below their peak of the late 1990s, the range of measures that could be said to have at least some environmental motivation has probably never been greater. In recent years, developments such as the climate change levy, aggregates levy, landfill tax and changes to the VAT system have all come into force, the system of vehicle excise duty has been reformed to give emissions greater importance, and systems of emissions trading have been implemented at national and EU levels.

This trend may well continue in the future if other taxes on plastic bags, energyinefficient items or domestic energy are implemented, or if existing measures such as council tax are reformed with explicit environmental concerns in mind. Carbon emissions in the UK, having fallen dramatically in the 1990s largely due to the 'dash for gas' in the energy generation sector, have started to rise again. Though the UK's Kyoto target looks set to be met, the more ambitious domestic targets for 2010 and 2050 look much more challenging without further policy reform. Whilst many recent developments in environmental taxation have focused on the business and industrial sectors, it seems that further reductions in emissions will depend on changing household behaviour, in terms of both domestic energy consumption and transport use. Policies designed to change behaviour through information and education alone may not be sufficient. Using the tax system to force consumers to face the environmental cost of their actions in the price they pay for particular goods and services may well be the best option from an economic efficiency point of view. However, any such measures will probably have to take into account concerns about equity, as they would undoubtedly have a proportionately greater impact on the poor than the rich. In addition, the political will required to introduce policies that directly impact on consumers is almost certainly much higher than the will needed for policies that largely affect business. 


\section{References}

Barrow, M. (2003), 'An economic analysis of the UK landfill permits scheme', Fiscal Studies, vol. 24, pp. 361-81.

Baumol, W. and Oates, W. E. (1971), 'The use of standards and prices for protection of the environment', Swedish Journal of Economics, vol. 73, pp. 4254.

BDS Marketing \& Research Ltd (2005), An Analysis of Trends in Aggregates Markets since 1990 - and the Effects of the Landfill Tax and Aggregates Levy, Lanark: British Aggregates Association (http://www.britishaggregates.com/documentation/doc32.pdf).

Bjorner, T. B. and Jensen, H. H. (2002), 'Energy taxes, voluntary agreements and investment subsidies: a micro-panel analysis of the effect on Danish industrial companies' energy demand', Resource and Energy Economics, vol. 24, pp. 22949.

Blow, L. and Crawford, I. (1997), The Distributional Effects of Taxes on Private Motoring, Commentary no. 65, London: Institute for Fiscal Studies (http://www.ifs.org.uk/comms/comm65.pdf).

Bovenberg, A. L. and de Mooij, R. A. (1994), 'Environmental levies and distortionary taxation', American Economic Review, vol. 84, pp. 1085-9.

Brechling, V. and Smith, S. (1994), 'Household energy efficiency in the UK', Fiscal Studies, vol. 15, no. 2, pp. 44-56.

British Aggregates Association (2005), An Analysis of Trends in Aggregates Markets Since 1990, and the Effects of the Landfill Tax and Aggregates Levy (http://www.british-aggregates.com/documentation/doc32.pdf).

Cambridge Econometrics (2006), Press Release, 26 May 2006 (http://www.camecon.com/whatsnew/releases/pdffiles/UKE3061.pdf).

Cambridge Econometrics and Policy Studies Institute (2005), Modelling the Initial Effects of the Climate Change Levy, London: HMRC (http://customs.hmrc.gov.uk/channelsPortalWebApp/downloadFile?contentID= HMCE_PROD1_023971).

Carbon Trust (2006), The Carbon Emissions Generated in All that We Consume (http://www.carbontrust.co.uk/Publications/CTC603.pdf).

Crawford, I., Smith, S. and Webb, S. (1993), VAT on Domestic Energy, Commentary no. 39, London: Institute for Fiscal Studies (http://www.ifs.org.uk/comms/comm39.pdf).

CSERGE, Warren Spring Laboratory and EFTEC (1993), Externalities from Landfill and Incineration, London: HMSO.

Davies, B. and Doble, M. (2004), 'The development and implementation of a landfill tax in the UK', in OECD, Addressing the Economics of Waste, Paris: Organisation for Economic Cooperation and Development (http://www1.oecd.org/publications/e-book/9704031E.PDF).

Department for Environment, Food and Rural Affairs (1998), The Review of the Water Abstraction Licensing System in England and Wales: A Consultation Paper, London: DEFRA

(http://www.defra.gov.uk/environment/consult/waterab/index.htm). 
Department for Environment, Food and Rural Affairs (2001a), Tuning Water Taking: Government Decisions following Consultation on the Use of Economic Instruments in relation to Water Abstraction, London: DEFRA (http://www.defra.gov.uk/ENVIRONMENT/water/resources/tuning/pdf/tun_wat .pdf).

Department for Environment, Food and Rural Affairs (2001b), Water Bill Consultation on Draft Legislation, London: DEFRA (http://www.defra.gov.uk/ENVIRONMENT/consult/waterbill/pdf/water.pdf).

Department for Environment, Food and Rural Affairs (2003a), A Study to Estimate the Disamenity Costs of Landfill in Great Britain: Final Report, London: DEFRA (http://www.defra.gov.uk/environment/waste/landfill/pdf/landfill_disamenity.pd f).

Department for Environment, Food and Rural Affairs (2003b), Mid Term Evaluation of the Aggregates Levy Sustainability Fund, London: DEFRA (http://www.defra.gov.uk/environment/waste/aggregates/pdf/mte.pdf).

Department for Environment, Food and Rural Affairs (2005), e-Digest of Environmental Statistics, June.

Department for Environment, Food and Rural Affairs (2006), e-Digest of Environmental Statistics (http://www.defra.gov.uk/environment/statistics/index.htm).

Department for Environment, Food and Rural Affairs and Department for Trade and Industry (2006), The UK Fuel Poverty Strategy: $4^{\text {th }}$ Annual Progress Report, 2006, London: DEFRA/DTI (http://www.dti.gov.uk/files/file29688.pdf).

Department for Environment, Transport and the Regions (2000), Air Traffic Forecasts for the United Kingdom 2000, London: DETR (http://www.dft.gov.uk/stellent/groups/dft_aviation/documents/pdf/dft_aviation pdf_503314.pdf).

Department of Health (2001), Birth Outcomes and Selected Cancers in Populations Living near Landfill Sites, London: HMSO (http://www.dh.gov.uk/assetRoot/04/06/63/70/04066370.pdf).

Department for Trade and Industry (2003), Our Energy Future - Creating a Low Carbon Economy, Cm. 5761, London: DTI (http://www.dti.gov.uk/files/file10719.pdf?pubpdfdload=03\%2F660).

Department for Transport (2006a), Transport Trends: 2005 Edition, London: DfT (http://www.dft.gov.uk/stellent/groups/dft transstats/documents/downloadable/d ft transstats 035650.pdf).

Department for Transport (2006b), Public Attitudes to Congestion and Road Pricing, London: DfT (http://www.dft.gov.uk/stellent/groups/dft transstats/documents/pdf/dft transsta ts_pdf 611869.pdf).

Department for Transport / HM Treasury (2003), Valuing the External Costs of Aviation, London: DfT, HMT (http://www.dft.gov.uk/stellent/groups/dft_aviation/documents/pdf/dft_aviation pdf_503315.pdf).

Dresner, S. and Ekins, P. (2006), 'Economic instruments to improve UK home energy efficiency without negative social impacts', Fiscal Studies, vol. 27, pp. 47-74. 
Dresner, S., Ekins, P. and Willis, R. (2006), A Green Living Initiative: Engaging Households to Achieve Environmental Goals, London: Policy Studies Institute.

Eaga Ltd (2004), Warm Front Report 2003/4.

Ekins, P. and Etheridge, B. (2006), 'The environmental and economic impacts of the UK Climate Change Agreements', Energy Policy, vol. 34, pp. 2071-86.

Environment Agency (2006), Environment Agency Scheme of Abstraction Charges (http://publications.environment-agency.gov.uk/pdf/GEH00406BKNP-ee.pdf?lang=_e).

European Environment Agency (2005), Greenhouse Gas Emissions and Removals June 2005 Assessment

(http://themes.eea.eu.int/IMS/IMS/ISpecs/ISpecification20040909113419/IAsse ssment1118392868101/view content).

Gillen, D. W., Morrison, W. G. and Stewart, C. (2004), Air Travel Demand Elasticities: Concepts, Issues and Measurement, Ottawa: Canadian Department of Finance (http://www.fin.gc.ca/consultresp/Airtravel/airtravStdy_e.html).

Glaister, S. and Graham, D. (2006), Road Pricing in Great Britain: Winners and Losers - Technical Report, London: Imperial College (http://trg1.civil.soton.ac.uk/itc/rpgb_main.pdf).

Hanly, M., Dargay, J. and Goodwin, P. (2002), Review of Income and Price Elasticities and the Demand for Road Traffic, London: Department for Transport, Local Government and the Regions (http://www.dft.gov.uk/stellent/groups/dft_econappr/documents/pdf/dft_econapp r_pdf_028644.pdf).

HM Revenue and Customs (2004a), Notice LFT1: A General Guide to Landfill Tax (http://customs.hmrc.gov.uk/channelsPortalWebApp/downloadFile?contentID= HMCE_CL_000509).

HM Revenue and Customs (2004b), Notice AGL1: Aggregates Levy (http://customs.hmrc.gov.uk/channelsPortalWebApp/downloadFile?contentID= HMCE_CL_000506).

HM Revenue and Customs (2006a), Report on the Evaluation of the Company Car Tax Reform: Stage 2, London: HMRC (http://www.hmrc.gov.uk/budget2006/company-car-evaluation.pdf).

HM Revenue and Customs (2006b), Air Passenger Duty Bulletin: February 2006 (http://www.uktradeinfo.com/index.cfm?task=airpass).

HM Revenue and Customs (2006c), Aggregates Levy Bulletin: February 2006 (http://www.uktradeinfo.com/index.cfm?task=aggregate).

HM Revenue and Customs (2006d), Climate Change Levy Bulletin: March 2006 (http://www.uktradeinfo.com/index.cfm?task=climate).

HM Revenue and Customs (2006e), Hydrocarbon Oils Duties Bulletin: March 2006 (http://www.uktradeinfo.com/index.cfm?task=bullhydro).

HM Revenue and Customs (2006f), Landfill Tax Bulletin: February 2006 (http://www.uktradeinfo.com/index.cfm?task=landfill).

HM Treasury (1993), Financial Statement and Budget Report, 1993-94, London: HMT.

HM Treasury (1995), Financial Statement and Budget Report, 1996-97, London: HMT.

HM Treasury (1997), 'Tax measures to help the environment', HMT News Release, 2 July 1997 (http://archive.treasury.gov.uk/pub/html/budget97/hmt4.html). 
HM Treasury (1999), Pre-Budget Report 1999, London: HMT.

HM Treasury (2000), Financial Statement and Budget Report, March 2000, London: HMT.

HM Treasury (2002), Tax and the Environment: Using Economic Instruments, London: HMT (http://www.hm-treasury.gov.uk/media/D54/07/adtaxenviron02332kb.pdf).

HM Treasury (2005), Tax Ready Reckoner and Tax Reliefs, London: HMT (http://www.hmtreasury.gov.uk/media/FA1/96/pbr05_taxreadyreckoner_223.pdf).

HM Treasury (2006a), The Climate Change Levy Package, London: HMT (http://www.hm-treasury.gov.uk/media/1E1/03/bud06_climate_169.pdf).

HM Treasury (2006b), Financial Statement and Budget Report, 2006, London: HMT (http://www.hmtreasury.gov.uk/budget/budget_06/budget_report/bud_bud06_repindex.cfm).

House of Commons Environment, Transport and Regional Affairs Committee (1999), The Operation of the Landfill Tax: Thirteenth Report, London: HMSO (http://www.publications.parliament.uk/pa/cm199899/cmselect/cmenvtra/150/15 007.htm).

House of Commons Environmental Audit Committee (2006a), Pre-Budget 2005: Tax, Economic Analysis, and Climate Change, Fourth Report of Session 200506, London: The Stationery Office Ltd (http://www.publications.parliament.uk/pa/cm200506/cmselect/cmenvaud/882/8 82.pdf).

House of Commons Environmental Audit Committee (2006b), Reducing Carbon Emissions from Transport, Ninth Report of Session 2005-06, London: The Stationery Office Ltd (http://www.publications.parliament.uk/pa/cm200506/cmselect/cmenvaud/981/9 81-i.pdf).

Inland Revenue (2004), Report on the Evaluation of the Company Car Tax Reform, London: Inland Revenue (http://www.hmrc.gov.uk/cars/cct_eval_rep.pdf).

Lamb, R. (2005), Environmental Levy on Plastic Bags (Scotland) Bill, SPICe Briefing 05/52 (http://www.scottish.parliament.uk/business/research/briefings05/SB05-52_000.pdf).

Lamb, R. and Thompson, M. (2005), Plastic Bags Policy in Ireland and Australia, SPICe Briefing 05/53

(http://www.scottish.parliament.uk/business/research/briefings-05/SB0553_000.pdf).

Leicester, A. (2005), Fuel Taxation, Briefing Note no. 55, London: Institute for Fiscal Studies (http://www.ifs.org.uk/bns/bn55.pdf).

Lord Marshall (1998), Economic Instruments and the Business Use of Energy, London: HM Treasury (http://www.hmtreasury.gov.uk/media/E9E/5D/EconomicInstruments.pdf).

Martin, A. and Scott, I. (2003), 'The effectiveness of the UK landfill tax', Journal of Environmental Planning and Management, vol. 46, pp. 673-89.

Morris, J. R. and Read, A. D. (2001), 'UK landfill tax and the Landfill Tax Credit Scheme: operational weaknesses', Resources, Conservation and Recycling, vol. 32, pp. 375-87. 
Nash, C., Mackie, P., Shires, J. and Nellthorp, J. (2004), The Economic Efficiency Case for Road User Charging, London: Department for Transport (http://www.dft.gov.uk/stellent/groups/dft_roads/documents/page/dft_roads_029 765.pdf).

National Audit Office (2003), Warm Front: Helping to Combat Fuel Poverty, London: The Stationery Office (http://www.nao.org.uk/publications/nao_reports/02-03/0203769.pdf).

OECD (2005), Factbook 2005, Paris: Organisation for Economic Cooperation and Development.

OECD (2006), Consumption Tax Trends: VAT/GST and Excise Rates, Trends and Administration Issues, 2006 Edition, Paris: Organisation for Economic Cooperation and Development.

Office for the Deputy Prime Minister (1999), Environmental Costs and Benefits of the Supply of Aggregates (Phase II), London: HMSO (http://www.communities.gov.uk/index.asp?id=1145616).

Office for National Statistics (2005), Environmental Accounts: Autumn 2005, London: ONS (http://www.statistics.gov.uk/downloads/theme_environment/EANov05.pdf).

Parry, I. W. H. (1998), The Double Dividend: When You Get It and When You Don't, Washington, DC: Resources for the Future (http://www.rff.org/ parry/Papers/double\%20dividend.pdf).

Parry, I. W. H. (2003), 'Fiscal interactions and the case for carbon taxes over grandfathered carbon permits', Resources for the Future, Discussion Paper no. 03-46 (http://www.rff.org/Documents/RFF-DP-03-46.pdf).

Pearce, B. and Pearce, D. (2000), 'Setting environmental taxes for aircraft: a case study of the UK', University College London, CSERGE Working Paper no. GEC 2000-26 (http://www.uea.ac.uk/env/cserge/pub/wp/gec/gec 2000_26.pdf).

Pearce, D. (2005), The United Kingdom Climate Change Levy: A Study in Political Economy, Paris: Organisation for Economic Cooperation and Development (http://www.oecd.org/dataoecd/54/41/34512257.pdf).

Pigou, A. C. (1920), The Economics of Welfare, London: Macmillan (see http://www.econlib.org/library/NPDBooks/Pigou/pgEWtoc.html).

Powergen Ltd (2005), Warm Front Annual Report 2005, Coventry: Powergen Ltd (http://www.defra.gov.uk/environment/energy/hees/pdf/powergen04-05ar.pdf).

Risk and Policy Analysts Ltd (2000), Economic Instruments in relation to Water Abstraction, London: Department for Environment, Transport and the Regions (http://www.defra.gov.uk/environment/water/resources/econinst/index.htm).

Sansom, T., Nash, C. A., Mackie, P. J., Shires, J. and Watkiss, P. (2001), Surface Transport Costs and Charges - Great Britain 1998, Final Report for the Department of the Environment, Transport and the Regions, Leeds: Institute for Transport Studies, University of Leeds.

Scottish Parliament Environment and Rural Development Committee (2005), Stage 1 Report on the Environmental Levy on Plastic Bags (Scotland) Bill, $13^{\text {th }}$ Report 2005 (Session 2), Edinburgh (http://www.scottish.parliament.uk/business/committees/environment/reports05/rar05-13-vol01-01.htm).

Smith, S. (1992), 'The distributional consequences of taxes on energy and the carbon content of fuels', European Economy, Special Edition, no. 1, pp. 241-68. 
Smith, S. (1995), “Green” Taxes and Charges: Policy and Practice in Britain and Germany, London: Institute for Fiscal Studies.

Social Market Foundation (2006a), The Economics of Road-User Charging in the UK, London: SMF.

Social Market Foundation (2006b), Road-User Charging and Taxation, London: SMF.

Society of Motor Manufacturers and Traders Ltd (2006), UK New Car Registrations by $\mathrm{CO}_{2}$ Performance: Report on the 2005 Market, London: SMMT (http://lib.smmt.co.uk/articles/sharedfolder/Publications/ACF22CC.pdf).

Stavins, R. N. (1998), 'What can we learn from the grand policy experiment? Lessons from $\mathrm{SO}_{2}$ allowance trading', Journal of Political Economy, vol. 12, no. 3, pp. 69-88.

Swedish Environmental Protection Agency (1995), Environmental Taxes in Sweden: Economic Instruments of Environmental Policy, Report no. 4745, Stockholm: SEPA.

Terkla, D. (1984), 'The efficiency value of effluent tax revenues', Journal of Environmental Economics and Management, vol. 11, pp. 107-23.

Transport for London (2005), Central London Congestion Charging: Impacts Monitoring - Third Annual Report, London: TfL (http://www.tfl.gov.uk/tfl/cclondon/pdfs/ThirdAnnualReportFinal.pdf).

Weitzman, M. L. (1974), 'Prices versus quantities', Review of Economic Studies, vol. 41, pp. 477-91. 